\title{
James DeWitt Andrews: Classifying the Law in the Early Twentieth Century ${ }^{*}$
}

\author{
Richard A. Danner**
}

19 June 2017

This paper examines the efforts of New York lawyer James DeWitt Andrews and others to create a new classification system for American law in the early years of the twentieth century. Inspired by fragments left by founding father James Wilson, Andrews worked though the American Bar Association and organized independent projects to classify the law. A controversial figure, whose motives were often questioned, Andrews engaged the support and at times the antagonism of prominent legal figures such as John H. Wigmore, Roscoe Pound, and William Howard Taft before his plans ended with the founding of the American Law Institute in 1923.

Key Words: James DeWitt Andrews, Henry T. Terry, John H. Wigmore, Roscoe Pound, William Howard Taft, American Bar Association, American Law Institute, Corpus Juris Project, American Academy of Jurisprudence, legal classification

\section{Introduction: Henry Terry Writes to the ABA}

In 1888 Edward Hinkley, the secretary of the American Bar Association, received a letter from New York lawyer Henry T. Terry on "the subject of arrangement of the law."1 Terry, then between two lengthy stints of teaching law in Japan, urged the ABA to solicit proposals for a "complete scientific arrangement of the whole body of [the law], generally accepted by the courts, the bar and the writers of treatises and digests, and in that sense authoritative." 2 The best arrangement could be published as an institutional work that would "take its place by the side of such books as Blackstone's or Kent's Commentaries."3

\footnotetext{
* C) Richard A. Danner 2017.

** Rufty Research Professor of Law and Senior Associate Dean for Information Services, Duke Law School, Durham, North Carolina U.S.A. I greatly appreciate the comments and valuable suggestions of Jennifer Behrens, Jane Bahnson, Mike Chiorazzi, and H. Jefferson Powell. As always, I thank Jane and Jennifer and the reference librarians of the Goodson Law Library at Duke for their research assistance. The paper relies heavily on correspondence and other unpublished writings by late nineteenth and early twentieth century figures in American law including James DeWitt Andrews, Roscoe Pound, William Howard Taft, Henry T. Terry, and John Henry Wigmore. The papers of Pound and Taft are generally available in microform and digital collections; thanks to the excellent assistance of George Pike and the staff of the Pritzker Legal Research Center I was able to examine Wigmore's original correspondence, held at the Northwestern University Archives, at the Northwestern Pritzker School of Law in Chicago. Andrews's papers seem not to have been collected, but much of his correspondence on the topics of this paper is available in other collections.

${ }^{1}$ See Transactions of the Eleventh Annual Meeting of the American Bar Association, 11 ANN. REP. A.B.A. 9, 19 (1888) (report of Edward Hinckley).

${ }^{2}$ Terry's letter was published in the following year's ABA proceedings along with the brief report of a special committee created to review the letter. See Letter from Henry T. Terry to the American Bar Association, Aug.1888, 12 ANN. REP. A.B.A. 327, 327-38 (1889) [hereinafter Terry Letter].

${ }^{3} I d$. at 338 .
} 
Four years earlier, Terry had published a thick book under the title: Some Leading Principles of Anglo-American Law, Expounded with a View to its Arrangement and Codification, in which he argued that the growing amount of published case law had created the need for a systematic arrangement, specific and detailed enough that "the principle or rule applicable in any given case can be seen to have its proper place in it." Terry emphasized that the arrangement should "make it as easy as possible for persons who have occasion to do so to find out what the law is on any point." 50 achieve this goal, the law should be arranged according to a "consistent and comprehensive plan [following] the principles of classification of other sciences." contemporary compilers of digests and treatises each used their own individual arrangements and classifications, "[t]he digests often have no logical or consistent order with which one can familiarize himself."7

The ABA was still a young organization in 1888. Founded 10 years earlier as an initiative of Simeon Baldwin of Connecticut, the ABA's founding members have been described as "savants of an American legal tradition ... [who] would uphold the purity of the Anglo-Saxon, English, New England common law against the tide of foreignness." 8 Like other contemporary bar associations, the Constitution called for the ABA "to advance the science of jurisprudence, [and] promote the administration of justice and uniformity of legislation throughout the Union,"9 goals in line with President James O. Broadhead's belief that the ABA should "rather aim to codify and harmonize, than to revolutionize or reform the law." ${ }^{10}$ Efforts at law reform in the United States have been led primarily by the organized bar, usually focusing on matters that could be dealt with

${ }^{4}$ HeNRY T. TERry, SOME LEADING PRINCIPLES OF ANGLO-AMERICAN LAW v (1884).

${ }^{5} I d$. at 607.

${ }^{6} \mathrm{Id}$. at 608 .

${ }^{7} I d$. at 611 . Terry closed his book by suggesting benefits of a code developed by a commission of learned lawyers, appointed and supervised by the ABA. Id. at 645. Codification, however, required the development of a truly philosophical synthesis "and an exact and scientific nomenclature ... elaborated for its expression." Id. at 610. His 1888 letter suggested that scientific arrangement would be of value both to supporters and to opponents of codification. Terry Letter, supra note 2 at 336.

${ }^{8}$ N. E. H. HULl, RosCOE POUND AND KARL LLEWELLYN: SEARCHING FOR AN AMERICAN JURISPRUdENCE 28 (1997).

${ }^{9}$ Constitution, 1 ANN. REP. A.B.A. 30 (1878). See Theodore J. Schneyer, The Incoherence of the Unified Bar Concept: Generalizing from the Wisconsin Case, 1983 AM. B. FouND. RES. J. 1, 25 (1983) ("Nearly all the voluntary bar associations that formed after 1870 listed among their formal purposes 'law reform,' 'advancing the science of jurisprudence,' or 'improving the administration of justice."'). See also Lawrence M. Friedman, Law Reform in Historical Perspective, 13 ST. LoUIS U.L.J. 351, 370 (1969) (the leaders of the nineteenth century bar "wanted nothing even remotely approaching a major overhaul of American law.") [hereinafter Friedman, Historical Perspective]; Simeon E. Baldwin, Founding of the American Bar Association, 3 A.B.A. J. 658 (1917) (materials demonstrating the founders' interests in improving state legislation by making it more uniform).

The current ABA Constitution lists a purpose "to promote throughout the nation the administration of justice and the uniformity of legislation and of judicial decisions." AMERICAN BAR ASSOCIATION CONSTITUTION AND BYLAWS 2015-2016, 1 ((2015).

${ }^{10}$ Proceedings of the First Annual Meeting of the American Bar Association, 1 ANN. REP. A.B.A. 21, 24 (1878). See also Walker Lewis, The Birth of the American Bar Association, 64 A.B.A.J. 996, 1002 (1978). At the first meeting, the Committee on Jurisprudence and Law Reform was charged with reporting on the state of the law regarding authentication of real estate instruments, and the execution of wills, "looking to greater uniformity therein." Proceedings of the First Annual Meeting, supra at 27. During the next few years, the ABA occasionally referred matters calling for greater uniformity to its committees, then in 1889 appointed a special committee on uniformity of laws which led to creation of the Conference of State Law Commissioners in 1892. See Richard E. Coulson, The National Conference of Uniform State Laws and the Control of Law-Making-A Historical Essay, 16 OKLA. CITY L. REV. 295, 323-30 (1991). 
only by lawyers and required consensus before action was taken. ${ }^{11}$ Lawrence Friedman found the results of the reform efforts of the ABA and local bar associations in the 1880s and 1890s to be "fairly meager." 12 Major change in the law might be possible through legislative and executive action, ${ }^{13}$ but was less likely through litigation and ordinary lawyers' work. ${ }^{14}$ Nonetheless, Friedman noted that "within the profession controversy can and does rage over law reform," 15 even if the issues involve what outsiders see as mere technical reforms.

The late nineteenth and early twentieth century efforts to classify American law are an example of attempted reform which aroused significant controversy within the legal profession. ${ }^{16}$ Terry's letter started 35 years of discussion within and around the ABA about the value and usefulness of classifying the law. William LaPiana lists classification as one of the major efforts at law reform in the late nineteenth and early twentieth centuries, noting: "The mere arrangement of the law on the printed page in accord with an appropriate scheme of classification would effect great good by elucidating the basic principles of the law. . ." ${ }^{\prime 17}$ Classification schemes pf various degrees of

${ }^{11}$ Lawrence M. Friedman, On Legal Development, 24 RUTGERS L. REV. 11, 43 (1969). In this article Friedman defined law reform in terms of "programs of planned legal change put forward by the organized bar, or by opinion leaders among the legal profession," applying the term to codification and other movements "for uniformity, consistency, and clarity in the law, to the restatements of the common law," as well as to efforts at procedural and court reform. Id. at 41 . He began a contemporaneous article by stating: "The phrase, law reform, has no exact, objective meaning." Friedman, Historical Perspective, supra note 9 at 351 ("Throughout most of its range of meaning, [legal reform] has referred to what one might call ... lawyers' law - to matters of primary concern to the legal profession ...." Id.)

Friedman believed that the early nineteenth century codification movement had called for real and substantive change by emphasizing simplification of the law, $i d$. at 369, but Robert Gordon viewed the 1820s codification debates as "overwhelmingly a preoccupation of ... a small elite of academically minded lawyers" and "the vast literature on the subject consists largely of anthems raised to the common law." Robert W. Gordon, Book Review, The American Codification Movement, A Study of Antebellum Legal Reform by Charles M. Cook (1981), 36 VAND. L. REV. 431, 434 (1983). Maxwell Bloomfield found that codification advocates such as William Sampson "worked for reform within the legal profession, looking to the scholar rather than the demagogue to carry through their program." Maxwell Bloomfield, William Sampson and Codifiers: The Roots of American Legal Reform, 1820-1830, 11 AM. J. LEGAL HIST. 234, 242 (1967). For a succinct description of codification discussions in the 1820s and after, see KUNAL M. PARKER, COMMON LAW, HistORY, AND DEMOCRACY IN AMERICA, 1790-1900 at 124-26. (2011). ${ }^{12}$ LAWRENCE M. FRIEDMAN, A History OF AMERICAN LAW 305 (3d. ed. 2005). He cites John Dillon's 1886 comment that "The lawyers as a body never did begin a reform of the law, and, judging from experience, they never will.” Id. at 303, quoting John F. Dillon, Codification, 20 AM. L. REV. 1, 1 (1886).

${ }^{13}$ Friedman, Historical Perspective, supra note 9 at 367. In the nineteenth century "the law was constantly changing; every new statute was in a sense a reform; so was every new doctrine and ruling." FRIEDMAN (2005), supra note 12 at 304. See also William P. LaPiana, "A Task of No Common Magnitude": The Founding of the American Law Institute, 11 NoVA L. REV. 1085, 1086 (1987) ("Not surprisingly, in the Anglo-American system, reform often involves legislation which is the antithesis of court-made law.").

${ }^{14}$ Friedman, Historical Perspective, supra note 9 at 367.

${ }^{15} \mathrm{Id}$. at 355 .

${ }^{16}$ See LaPiana, supra note 13 at 1107 ("[t]he classification movement . . . drew its impulse from and was directed by the legal profession itself."). See generally Gregory S. Alexander, The Transformation of Trusts as a Legal Category, 1800-1914, 5 LAW \& HIST. REV. 303, 304, 306 (1987) (noting discussions in contemporary treatises, and among academics and elite lawyers). Alexander found that the interest in classification during this period stemmed from several factors including the thought that classification of the law could be the means for law reform. Id. at 310-13.

${ }^{17}$ LaPiana, supra note 13 at 1094. In his history of American Law, Lawrence Friedman found that reformers believed that: "A legal order which is clear, orderly, systematic (in its formal parts), which has the most structural beauty, which most appeals to the modern, well-educated jurist, is also the best and the most efficient." FRIEDMAN 
comprehensiveness were used in digests and other tools to locate cases throughout the 1800s. Gregory Alexander notes that, although classification schemes have been generally overlooked by legal historians, they are worthy of attention as "codes by which participants in the legal system organize and understand their experiences as agents of the system . . . It seems impossible, then, to understand deeply the legal thought of any period without paying attention to its arrangement of legal categories." 18 N.E.H. Hull saw the attempts of some late nineteenth century "[o]lder formalists ... [to perfect] their schemas for legal classification" as a way to deal with the inconsistencies in the law brought to the forefront by the growth in published reports of cases. ${ }^{19}$

This paper explores late nineteenth and early twentieth century efforts to classify United States law. Terry's 1888 letter was referred to an ABA special committee on classification. Although that committee was skeptical of Terry's proposal, James DeWitt Andrews, who chaired the committee from 1901-1908, became the foremost advocate of classification in the early twentieth century, both within the ABA and through independent initiatives to organize and to classify the law. Most notable among those efforts was the American Academy of Jurisprudence, which he established in 1913 with support from William Howard Taft, Roscoe Pound, Elihu Root and other prominent legal figures. In the early 1920s, Andrews's attempts to engage the ABA in a joint classification plan with the Academy were rejected when the ABA turned instead to support of the American Law Institute. From the outset, the ALI rejected calls to develop a comprehensive classification of the law prior to starting its restatement project, but commissioned Pound to create a classification plan sufficient to begin the work. Although Pound's effort was left incomplete, Jay Feinman calls it the last attempt "to present a comprehensive approach to the study of classification." 20

\section{The ABA and Codification}

Terry's proposal arrived after several years of often heated discussion over codification at ABA meetings. ${ }^{21}$ In his 1884 annual meeting address, John F. Dillon asked whether in light of the

(2005), supra note 12 at 304-05. But this theory was rarely made explicit or tested empirically, and "was in all probability wrong, since it exaggerated the impact of technical changes and the value of rules on paper." Id. at 305 .

Ferdinand Stone notes that "[t] he notion of a single fabric, a corpus, is one dear to man's heart." Ferdinand Fairfax Stone, A Primer on Codification, 29 TUL. L. REv. 303, 305 (1955). Stone also points out the connections between classification and codification: 1) that the laws contained in the code should be arranged systematically, and 2) that the code should in all ways be dealt with as a single fabric.

${ }^{18}$ Alexander, supra note 16 at 305 (1987). In his study of the jurisprudence of classification, Jay Feinman found that, although classification had seen little attention since the $1920 \mathrm{~s}$, "[t]he relative lack of attention is not a sign of the problem's insignificance." Jay M. Feinman, The Jurisprudence of Classification, 41 STAN. L. REv. 661, 662 (1989).

${ }^{19}$ N.E.H. Hull, Restatement and Reform: A New Perspective on the Origins of the American Law Institute, 8 LAW \& HIST. REV. 55, 57 (1990). See generally Alexander, supra note 16 at 305-14 ("Although categorical ordering appears in English and American legal texts throughout the nineteenth century (and earlier), it was especially prominent in late nineteenth-century writings." Id. at 306). Alexander applies Duncan Kennedy's term "Classical" to a range of writers on the subject of classification in the late nineteenth century, $i d$. at $306 \mathrm{n}$. 5, and is particularly insightful on the influences of Holmes. Id. at 308-09, 312-13.

${ }^{20}$ Feinman, supra note 18 at 663 n.4 (summarizing the legal classification literature).

${ }^{21}$ In the early 1880s, the New York legislature's consideration of a comprehensive Civil Code provoked debates in law journals and newspapers, and within the ABA. For a short history, see Mathias Reimann, The Historical School against Codification: Savigny, Carter, and the Defeat of the New York Civil Code, 37 AM. J. ComP. L. 95, 98-101 (1989). See also FRIEDMAN (2005), supra note 12 at 302 ("The codification movement is one of the great set pieces 
burdens posed by the growing mass of decisions and increasing amounts of legislation, "legislative action [ought] to be so expanded as to embrace CODIFICATION within its remedial endeavors?"22 Although he found it inexpedient, if not chimerical, to think that a code could embody "rules applicable to all the complicated transactions of modern business and society," Dillon believed it was both feasible and desirable to create "a thorough revision and systematic statement . . as far as it can be expediently done, of the law on the great subjects which relate to the ordinary business and life of the people." 23

The address prompted two resolutions. The first requested that the Committee on Judicial Administration and Remedial Procedure prepare a report "on the evils of the system of reporting the decisions of the courts." 24 The second, offered by codification advocate David Dudley Field, ${ }^{25}$ called for a special committee to report on whether "the present delay and uncertainty in judicial administration can be lessened and, if so, by what means." 26 The following year, Field and Dillon submitted the special committee's report, which included a list of fourteen recommendations for reducing delay and uncertainty, ${ }^{27}$ the thirteenth stating: "The law itself should be reduced, as far as possible, to the form of a statute." ${ }^{28}$ For two days members debated whether that language would commit the ABA to supporting codification. ${ }^{29}$ Field spoke in favor of the recommendation ("I am for codification, pure and simple."), but argued that its language was mild: No one could deny that the law should be reduced to statutory form as far as possible. "The question is whether it is

of American legal history.”); Andrew P. Morriss, Codification and Right Answers, 74 CHI.-KenT L. REV. 355, 36667 (1999).

In 1881, ABA President Edward J. Phelps questioned the capabilities of legislatures to create comprehensive codes to replace existing bodies of common law. See Address of Edward J. Phelps, 4 ANN. REP. A.B.A. 141, 169-73 (1881). The following year, Thomas Semmes offered an address intended to introduce ABA members to the civil law as practiced in Louisiana. Thomas J. Semmes, The Civil Law as Transplanted in Louisiana, 5 ANN. REP. A.B.A. 243 (1882).

${ }^{22}$ John F. Dillon, Annual Address: American Institutions and Laws, 7 ANN. REP. A.B.A. 203, 228 (1884).

${ }^{23} \mathrm{Id}$. at 229-30.

${ }^{24}$ Transactions of the Seventh Annual Meeting of the American Bar Association, 7 ANN. REP. A.B.A. 5, 48 (1884). In 1885, the committee responded with another resolution directing it "to formulate the question." Transactions of the Eighth Annual Meeting of the American Bar Association, 8 ANN. REP. A.B.A. 5, 39 (1885). The following year, it offered a short report and resolution rejecting the idea that the evils of the growth in reports could be remedied "by legislative restrictions of absolute freedom in the publication of adjudged cases." Report of the Committee on Judicial Administration and Remedial Procedure on Existing Evils in the System of Reporting the Decisions of the Courts, 9 ANN. REP. A.B.A. 312 (1886). The problems of the reports left that committee's agenda, but would be taken up in 1894 by a new committee focusing on law reporting. See infra text accompanying notes ___ to _ ${ }^{25}$ Robert Gordon calls Field "that inexhaustible one man [sic] codifying machine ...." Gordon, Book Review, supra note 11 at 435 .

${ }^{26}$ Transactions of the Seventh Annual Meeting, supra note 24 at 74.

${ }^{27}$ Report of the Special Committee Appointed to Consider and Report Whether the Present Delay and Uncertainty in Judicial Administration Can Be Lessened, and if so, by What Means, 8 ANN. REP. A.B.A. 323, 362-64 (1885) By the time of the 1885 meeting, one special committee members had died; two others were out of the country. See Circular, 9 ANN. REP. A.B.A. 387, 387 (1886). The efforts of the special committee and the concerns with the growing amount of case law are detailed in JOHN F. DILLON, THE LAWS AND JURISPRUDENCE OF ENGLAND AND AMERICA 242-253 (1894). Dillon suggests that Field was the primary author of the report. Id. at 244.

${ }^{28}$ Report of the Special Committee Appointed to Consider and Report, supra note 27 at 364.

${ }^{29}$ Transactions of the Eighth Annual Meeting, supra note 24 at 42-62, 66-84. At the beginning of the second day, the original resolution to accept the entire special committee report was withdrawn in favor of one calling for approval of its conclusions and resolutions, which did not specifically mention codification. $I d$. at 67,73 (comments of John F. Dillon). 
possible on a given subject." ${ }^{30}$ Eventually, the membership voted to postpone consideration of the thirteenth recommendation until the following year. ${ }^{31}$

In 1886 the carried-over resolution again caused extensive debate, ${ }^{32}$ during which Field expressed frustration with his colleagues' lack of interest in law reform. ${ }^{33}$ When he finished, Resolution 1 was passed in amended form, reading: "The law itself should be reduced, so far as its substantive principles are settled, to the form of a statute." ${ }^{34}$ In following years, codification was occasionally mentioned in passing in ABA meeting addresses and other remarks, ${ }^{35}$ but no further actions were proposed. In his own 1889 presidential address, Field barely mentioned it. ${ }^{36}$

${ }^{30} I d$. at 75 (comments of David Dudley Field).

31 The committee's other recommendations were approved. Id. at 79-83.

${ }^{32}$ Report of the Special Committee on Delay and Uncertainty in Judicial Administration, 9 ANN. REP. A.B.A. 325, 356-58 (1886). The report included a total of ten recommendations, must of which from questions distributed to members of the bar. See Circular, supra note __. Committee member Courtland Parker filed a separate report. See Report of Courtland Parker, 9 ANN. REP. A.B.A. 363 (1886).

${ }^{33}$ Transactions of the Ninth Annual Meeting of the American Bar Association, 9 ANN. REP. A.B.A. 3, 63-72 (1886)

("What is the reason of the indifference of lawyers to the reform of the law? ... Too many of our calling look upon it not as a profession but as a craft. And it is because they so regard it that they do not strive to elevate it." Id. at 71).

The evening before, Dillon had delivered a paper requested by the Committee on Judicial Administration, in which he discussed Jeremy Bentham's arguments for codification, but did not mention the resolution. See John F. Dillon, Law Reports and Law Reporting, 9 ANN. REP. A.B.A., 7, 257, 265-66 (1886). In the Annual Address, just before discussion of the committee report, Thomas Semmes detailed the influences of Roman law on the beginnings and development of the law of England, asking: "What is there then in the origin, the history, or the development of the common law which renders its codification impracticable?" Thomas J. Semmes, Annual Address, 9 ANN. REP. A.B.A. 189 (1886).

${ }^{34}$ Transactions of the Ninth Annual Meeting, supra note 33 at 74. An amendment to add the sentence: "This Association does not, however, favor or oppose what is known as codification" failed. Id. at 73.

${ }^{35}$ In 1888 former Ohio governor George Hoadly chided American lawyers for their limited vision ("Lawyers live too often intellectually in England only, and not in the world."), then urged his own generation to take on "the work of committing the body of the law to written form." George Hoadly, Annual Address, 11 ANN. REP. A.B.A. 219,220 (1888). ("If we admit that the great work of codification has not yet been properly done, let us, instead of finding fault with Mr. Field and his colleagues, seek to improve upon their labors, and to present better formulae." Id. at 243-44).

${ }^{36}$ Address of David Dudley Field, 12 ANN. REP. A.B.A. 149, 231 (1889) ("I shall not here enlarge upon what I conceive to be the advantages of codification to the lawyer and the judge; I will regard it only in its relations to the great body of citizens ....”). 
Terry's 1888 letter was referred to a new special committee, ${ }^{37}$ which published the letter as its report for $1889 .{ }^{38}$ After the death of the chair in 1890, the original committee was discharged and new members appointed. ${ }^{39}$ In 1891, Emlin McClain delivered a detailed report on the proposal. ${ }^{40}$

In the letter, as in most of his writings, Terry referred to "arrangement" rather than to classification, presumably because of the difficulties he saw in creating legal categories that were neither vague nor arbitrary. ${ }^{41}$ The special committee report suggested that arrangement and classification were synonymous, but discussed classification, which it saw as having had two primary objectives: first, to help lawyers comprehend the law and, second, to improve their ability to locate specific precedents. The report concluded that these objectives were "not necessarily consistent, and it will be found that they are not practically so."42 As a result, separate classifications were needed, although the terminology for each should "conform ... to existing usage." 43 The bulk of the report discussed possible divisions for a future classification scheme, closing with a proposed "Classification of the Law," notes, and bibliographic references. ${ }^{44}$ Neither Terry's proposal nor the Committee's scheme were discussed at the annual meeting. For the next five years, the Committee failed to report, although classification became an occasional topic of discussion in the journals. ${ }^{45}$

${ }^{37}$ Transactions of the Eleventh Annual Meeting (1888), supra note 1 at 22. At the 1889 annual meeting, the first chair of the special committee called it the committee on "The Expression of the Law." See Transactions of the Twelfth Annual Meeting of the American Bar Association, 12 ANN. REP. A.B.A. 9, 22 (1889). The committee's 1889 report was headed "Committee on the Arrangement of the Law." See Report of the Committee on the Arrangement of the Law, $i d$. at 327. In 1891, before delivering the special committee's report on Terry's letter, Emlin McClain informed the membership that the committee was properly called Committee on the Classification of the Law. See Transactions of the Fourteenth Annual Meeting of the American Bar Association, 14 ANN. REP. A.B.A. 3, 55 (1891). But see Transactions of the Fifteenth Annual Meeting of the American Bar Association, 15 ANN. REP. A.B.A. 3, 4 (1892) (referring to the "Special Committee on Expression and Classification of the Law"). Throughout its life (1888-1908), the lists of committee members in the ABA annual reports listed it as "Special Committee on Classification of the Law."

${ }^{38}$ See Terry Letter, supra note 2 at 327.

${ }^{39}$ Transactions of the Thirteenth Annual Meeting of the American Bar Association, 13 ANN. REP. A.B.A. _, 40-41 (1890)

${ }^{40}$ Transactions of the Fourteenth Annual Meeting, supra note 37 at 55.

${ }^{41}$ For Terry, formal classification was particularly problematic in law because it was necessary to act on divisions and categories even if they were arbitrary or vague. See TERRY, SOME LEADING PRINCIPLES, supra note 4 at 47-48. In his letter to the ABA, Terry referred to "complete scientific," "scientific and rational," "philosophical," "severely and inexorably logical," and "logical and natural" arrangements of the law. See Terry Letter, supra note 2.

${ }^{42}$ Report of the Committee on Classification of the Law, 14 Ann. Rep. A.B.A. 379, 383 (1891).

${ }^{43} I d$. at 384.

${ }^{44} I d$. at $402-408$.

${ }^{45}$ In 1892 McClain published an article in which he discussed the connections between what he termed "theoretical classifications" and the practical needs of the bar. See Emlin McClain, Classification of the Law for Lawyers, 26 AM. L. REV. 223 (1892). He acknowledged that, in seeking precedents, "the practical lawyer ... is likely to ignore the theoretical classification as of no use to him whatsoever," but criticized the "heterogeneous arrangements of matter" in contemporary digests and texts, which left practitioners with "no assurance when cases on point are found that other cases equally in point are not put under some inconceivable bad head elsewhere ...." The only solution was "[a] rigorous, systematic arrangement of matter under well known [sic] heads having a definite scope with careful subdivisions" in harmony with general usage. Only with a scientific classification could "each topic be limited to its proper scope" and cases placed under proper headings in practical applications." Id. at 224-25.

Others were less optimistic about the practical benefits of classification. Frederick Pollock argued that because the facts of a case might be the subject of more than one rule, "it is not possible to make any clear-cut division of legal rules." Divisions at high orders of generality are of little concern to practicing lawyers, who think first of 


\section{ABA Committee on Law Reporting and Digesting}

In response to the bar's concerns about the continued growth and duplication in law reports, the ABA appointed a Special Committee on Law Reporting in $1894 .{ }^{46}$ That committee's first report focused on the reports, while noting the need for more uniform indices and digests. ${ }^{47}$ In 1895 , it became a standing committee with the name Committee on Law Reporting and Digesting. ${ }^{48}$ By assigning concerns about digests to the new committee, rather than to the then quiescent Special Committee on Classification, the action seemed to distinguish scientific or philosophical classification of the law as urged by Terry, McClain, and others from the practical issues of digest classification. President James Carter, however, noted the connection between the scientific and the practical:

Nothing can be of greater assistance to a lawyer than to have all the topics of the law scientifically classified and arranged. If there could be such a classification and arrangement, that should be the one obviously, as it would seem to me, which should be adopted by reporters, and it would be of vast utility, not only in consulting books of reports, but it would tend in a manner to govern the arrangement of textbooks, if there should be any general acquiescence in it. $^{49}$

Classification Committee chair McClain did not attend the 1895 ABA meeting. The following year, he noted potential conflicts in jurisdiction between the two committees, but concluded:

I fancy that the functions of the two committees will not be found to conflict with each other for the reason that the Committee on Law Reporting must necessarily have in mind rather indexing and digesting, while [the Classification] Committee did not have that in mind as its fundamental or important subject, but rather the determination of the general headings under which particular subjects would be discussed. ${ }^{50}$

\footnotetext{
"speedy and convenient reference, and the working arrangements of professional literature are made accordingly." Writers with greater ambitions were "destined to disappointment by the nature of things." Frederick Pollock, Divisions of Law, 8 HARV. L. REV. 187, 187-88 (1894). Russell Curtis published a classification that he believed was "more convenient than any other yet proposed." Russell H. Curtis, Classification of Law, 4 ANNALS AM. ACAD. POLITICAL \& SOC. SCI. 738, 738 (1894).

${ }^{46}$ Transactions of the Seventeenth Annual Meeting of the American Bar Association, 17 ANN. REP. A.B.A. $72-73$ (1894).

${ }^{47}$ Report of Committee on Law Reporting, 18 ANN. REP. A.B.A. 343, 352 (1895). The report also noted, however, that the current digests had "made it comparatively easy, considering the mass of decisions, to make an exhaustive investigation of any question." Id. at 356.

${ }^{48}$ Transactions of the Eighteenth Annual Meeting of the American Bar Association, 18 ANN. REP. A.B.A. 30-31

(1895). In proposing the change, Simeon Baldwin said:

The importance of the subject of law reporting and law digesting, both to the bar and bench, cannot of course be over-estimated, and a standing committee reporting annually, if they saw occasion, could make recommendations for action from a higher and better vantage ground, and with a broader view of the subject than any special committee.

Id. at 30. The 1878 ABA constitution provided for five standing committees; the Committee on Law Reporting and Digesting was the first additional standing committee. EDSON R. SUNDERLAND, HISTORY OF THE AMERICAN BAR ASSOCIATION AND ITS WORK 21-22 (1953).

${ }^{49}$ Transactions of the Eighteenth Annual Meeting, supra note 48 at 39 (comments of James C. Carter).

${ }^{50}$ Transactions of the Nineteenth Annual Meeting of the American Bar Association, 19 ANN. REP. A.B.A. 3, 17-18 (1896).
} 
In 1896 the Committee on Law Reporting and Digesting criticized current digests and indexes for inconsistency and poor arrangement. Although a thorough, carefully-compiled digest of all decisions was almost as necessary and desirable as official publication of cases, existing digests did no more than "tend to uniformity." 51 The committee echoed Terry in concluding that, despite the efforts of commercial publishers, a satisfactory uniform index could not be created "through private effort or enterprise," but would require either concerted action either by the body of court reporters (perhaps brought together by the ABA), or a commission created by the federal government. ${ }^{52}$

Two years later, under new chair Edward Q. Keasbey, the Committee again focused on whether the publishers were meeting the bar's need for a common plan of arrangement. ${ }^{53}$ Its report emphasized the importance of uniformity in schemes of classification and in terminology, and argued that the "best arrangement of division and sub-division cannot be determined on theoretical consideration," but on "the habits of thought and the actual wants of the men who are to use it." 54 Because "[t]he purpose of a digest is to enable us to find the law contained in the reports ... [i]t does not matter so much what plan of classification is adopted as that we shall know clearly what the plan is, and that the same plan is always followed." 55 Then, in a reversal of its 1896 comments criticizing commercial digests, the Committee concluded that the publishers had indeed supplied "uniform systems of reporting and digesting common to all, and a basis, at least, of a common system which shall be satisfactory to all." 56 As a result, "the hope of uniformity lies in the two series of digests of the reports of the whole country by which the bar of the whole country is now made acquainted with the decisions of all the courts alike." 57 As a result, there was no need for the bar or any official authority to be directly involved in the digesting of decisions beyond offering suggestions for improvement to the publishers.

\section{James D. Andrews and the Special Committee}

After its report on Terry's proposal in 1891, the Special Committee on Classification failed to report until 1896. That year's short report was largely a gloss on the classification system proposed in its 1891 report on Terry's letter, and suggested "that such a classification would not be found

\footnotetext{
${ }^{51}$ Report of Committee on Law Reporting and Digesting, 19 ANN. REP. A.B.A. 398, 402 (1896).

${ }^{52} I d$. at $402-03$.

${ }^{53}$ Report of Committee on Law Reporting and Digesting, 21 ANN. REP. A.B.A. 437, 441 (1898). Keasbey would serve as chair from 1897 until the committee's demise in 1919.

${ }^{54} \mathrm{Id}$. at 448.

${ }^{55} \mathrm{Id}$. at 449.

56 The report made a veiled reference to West Publishing Company as "[ $\mathrm{t}]$ he agency...by which the demand for a multiplicity of decisions has been increased, [and which] has in itself provided some remedy for the difficulties which have been created." Id. Although not mentioned directly, the West Company viewed the Committee's recognition as a formal endorsement by the ABA. See WiLliam W. MARVIN, WeSt PUBLISHING COMPANY: ORIGIN GROWTH LEADERSHIP 73-74 (1969) ("The American Bar Association at its next annual meeting, 1898, formally endorsed the American Classification Plan as the model for modern digesting.").

${ }^{57}$ Report of the Committee on Law Reporting and Digesting (1898), supra note 53 at 448 (referring to West's American Digest and Lawyers' Cooperative's General Digest, each of which used the West classification system). In 1900, the Committee repeated its suggestion that "the system with which we are all equally familiar" be adopted in the states as the basis for the "standard to which all the digests should substantially conform." Report of the Committee on Law Reporting and Digesting, 23 ANN. REP. A.B.A. 376, 377 (1900). In its 1899 report the committee listed new reporters and digests published since its previous report. Report of the Committee on Law Reporting and Digesting, 22 ANN. REP. A.B.A. 454 (1899). The lists of new digests became a regular feature of the committee reports.
} 
itself of much practical value, but that it would form a foundation on which an arrangement of subjects for practical purposes might be based." 58 The Committee hoped to make at least a partial report on its continuing work by the next ABA meeting, ${ }^{59}$ but did not report in 1897. In 1898 the only committee member present told the assembly that he had "no report to make and the law will have to remain unclassified for another year." 60

Chicago attorney James DeWitt Andrews ${ }^{61}$ briefly revitalized the Special Committee after being appointed chair in 1901, then became a prominent voice on classification of law for the next twenty years. At the time of his appointment, he had been practicing law in Chicago for ten years, after completing his studies at Albany Law School in 1879 and a short stint in the city of Sterling. After coming to Chicago to work with Richard Prendergast, ${ }^{62}$ by 1895 the Chicago Legal News listed him as senior partner in the firm of Andrews, Miller \& Fuller, and described his work in the editorial department of the publisher Callaghan $\&$ Co. ${ }^{63}$ He taught at Northwestern and became a prolific writer and editor, once called "Chicago's Leading Law Writer" by the Chicago Legal News, ${ }^{64}$ as well as one of the most versatile and able of our lawyers." In 1896, however, the Legal News reported that "[a]fter practicing law for a time he found that it was not conducive to his health, and took up literary work [as] the law critic of the law publishing house of Callaghan \& Company." 65 By 1897 he had returned to practice. ${ }^{66}$ In 1900, the American Lawyer noted that he had formed a partnership with several others under the name Aldrich, Andrews, Mathias \& Phipps. ${ }^{67}$ In 1903, he relocated his practice to New York City.

In 1896 Andrews had edited an edition of the works of founding father James Wilson and would frequently refer in later years to Wilson's ideas on classification. ${ }^{68}$ Although Wilson's thoughts were fragmentary, ${ }^{69}$ for Andrews: "The important thing ... is that he pays no regard to the primary

\footnotetext{
${ }^{58}$ Report of Committee on Expression and Classification of the Law, 19 Ann. Rep. A.B.A. 405, 405 (1896).

${ }^{59} I d$. at 406. No further written reports were offered until 1902.

${ }^{60}$ Transactions of the Twenty-First Annual Meeting of the American Bar Association, 21 Ann. Rep. A.B.A. 3,31 (1898).

${ }^{61}$ Andrews's middle name was sometimes published as DeWitt, sometimes as De Witt. In this paper, it is normalized as DeWitt.

62 See James DeWitt Andrews, Prominent Men of the Great West 210, 211 (John A. Campbell, ed., 1902).

${ }^{63}$ James DeWitt Andrews, 27 CHI. LEGAL NEWs 175, 175-76 (1895). The article praises Andrews's early work as practitioner and prosecutor in Whitesides County, Ill.

${ }^{64}$ James DeWitt Andrews, Chicago's Leading Law Writer, 32 CHI. LEGAL News 310, 310 (1900). His 1894 edition of Henry Stephen's Principles of Pleading was particularly well-received. See id. (noting that the book "received hearty commendation and has had a wide and continuous sale"). A second edition was published in 1901.

${ }^{65}$ Mr. J.D. Andrews Accepts a Call to be a Candidate for Representative--the Platform, 28 CHI. LEGAL NEWS 282 , 282 (1896).

${ }^{66}$ See Lawyers, 5 AM. LAW. 505, 506 (1897) ("James Dewitt Andrews, who has been so widely and favorably known through his connection with the publishing house of Callaghan \& Co., has recently fitted up an elegant suite of rooms in the Marquette building for the practice of law. Mr. Andrews is one of the ablest lawyers in the city.").

678 AM. LAW. 363 (1900).

68 THE WORKS OF JAMES WILSON (2 Vol. James DeWitt Andrews, ed. 1896).

${ }^{69}$ In 1910 Andrews wrote that Wilson "left no formal outline and did not state any general principle upon which he proposed to proceed. He, however, stated that the arrangement could not be alphabetical and must be logical and, in various parts of his works, indicates his belief in the application to our law of the general principles of logical classification." James DeWitt Andrews, The Next Great Step in Jurisprudence, 19 YALE L.J. 486, 488 (1910) [hereinafter Andrews, Next Great Step].

In 1791, while an associate justice of the U.S. Supreme Court, Wilson was asked by the Pennsylvania state legislature to revise and prepare a digest of Pennsylvania law. He outlined his intentions for the digest and its
} 
classification of the law followed by Blackstone .... Wilson's classification is that of the jurists. He was, doubtless, the greatest English-speaking civilian of the age in which he lived." 70

Andrews viewed Wilson as "a pioneer in the field of Jurisprudence" who taught that "as a science, Jurisprudence depends upon analysis and classification of subjects according to genera and species . ..."71 Andrews, too, saw jurisprudence and classification as tightly related. In 1910, he wrote: "Classification is clearly the basis of logical science; classification is an essential part of the definition of jurisprudence; classification is an essential part of the work of codification and of systematic consolidation. It is by means of classification and concise statement that any complex mass is reduced to system. System is the creator of simplicity."72

Andrews's short 1895 article on legal education introduced concerns that would often reappear in his writings and drive his efforts to organize a comprehensive classification of American law. Concerned that the case method of legal instruction prevented law students from obtaining a clear idea of the body of the law and its parts, he argued for study of jurisprudence and institutional works, especially those of Gaius, Matthew Hale and Blackstone, ${ }^{73}$ noting that " $[\mathrm{t}]$ he United States has as yet no treatise approximating in any degree, the unifying character of the work of these

classification in a letter to the speaker of the state house of representatives. See Bird Wilson, Preface, in 1 THE WORKS OF THE HONOURABLE JAMES WILSON, L.L.D. iii, iv-xiv (1804).

Charles Cook suggests Wilson's later law lectures (prepared for the College of Pennsylvania) demonstrate how Wilson would have organized the digest. CHARLES M. COOK, THE AMERICAN CODIFICATION MOVEMENT, A STUDY OF ANTEBellum Legal Reform 36 (1981). See also PERry Miller, The Life of the Mind In AMERICA $239-240$ (1965). In the introduction to a 1967 edition of Wilson's works, Robert McCloskey wrote that "No more than half of the lectures composed were actually delivered; even the complete written text (unpublished until after the author's death) leaves serious gaps in the analytic structure, and some of the chapters deteriorate into turgid generality or into the dreary recitation of hornbook facts, as if the professor lacked time to do his homework properly." Robert McCloskey, Introduction, 1 WORKS OF JAMES WILSON 1, 37 (Robert McCloskey, ed., 1967). Mark David Hall called the Philadelphia lectures “[p] erhaps Wilson's most important contribution to American jurisprudence.” MARK DAVID Hall, The POLITICAL AND LEgAL PhILOSOPHY OF JAMES WILSON 1742-1798 at 27 (1997).

Andrews's edition of Wilson's papers was well-received, see, e.g., Book Review, The Works of James Wilson, 4 N.W. L. REV. 244 (1896) ("[A]s the only distinctive treatise on American Jurisprudence, we regard the work as very essential to the student or practitioner desiring a comprehensive knowledge of the fundamental principles of our law."). One review noted that Andrews "may be inclined to exaggerate the authority of the able jurist upon the questions he discusses from a natural partiality for an author whose work he has so well edited." J. Randolph Tucker, 2 VA. L. REG. 234, 236 (1896). A 2010 article credits Andrews's edition for Wilson's turn-of-the-century "renaissance," but also notes that Andrews displayed the "hagiographic tendencies" of nineteenth century histories. Nicholas Pedersen, The Lost Founder: James Wilson in American Memory, 22 YALE J.L. \& HumAN. 257, 301 (2010). On the increased interest in Wilson after Andrews's edition, see generally HALL, supra at 1-4.

In a 1901 lecture on Wilson, Andrews pointed out that "James Wilson is, in a peculiar sense, entitled to my own veneration and affection." James DeWitt Andrews, James Wilson and his Relation to Jurisprudence and Constitutional Law, 49 AM. L. REV. 708, 708 (1901). See also James DeWitt Andrews, Obligation of a Contract, 3 LAW STUDENT'S HELPER, 163, 163 (1895) (crediting Wilson with adding the "obligation of a contract" clause to the U.S. Constitution, and noting that "it is conceded without question that James Wilson was the best civilian of the period, if, indeed, it is too much to say, he was the only thorough civilian among those connected with the formation of our Constitution."). For a similar claim regarding the phrase: “created equal," see Andrews's letter to the editor of the Green Bag, 7 GREEN BAG 307 (1895).

${ }^{70}$ Introductory Lecture-Of the Study of Law in the United States, in 1 THE WORKS OF JAMES WILSON (1896), supra note 8 at 1,40 n.1).

${ }^{71}$ James DeWitt Andrews, James Wilson and His Relation to Jurisprudence and Constitutional Law, 49 AM. L. REG. 708, 711 (1901).

72 See Andrews, Next Great Step, supra note 69 at 489.

73 James DeWitt Andrews, Legal Education in the United States, 3 AM. LAW. 55, 56 (1895). 
writers." Like Henry Terry, he urged the ABA to turn its attention to developing "an arrangement of the law in systematic order, which would of itself indicate the system of legal education to be followed because it would embrace the whole body of the law, indicate its divisions, and the relations of the parts." As the law grew more complex, "each year calls for greater care in the arrangement and classification of legal subjects." 74 A few months later, he wrote: "We must stop calling everything which requires study to understand obnoxious and technical. Was ever a science entirely simple? Is not the basis of science the application of classification? We must be willing to study if we desire to be called members of a learned profession."75

The 1895 Chicago Legal News profile noted that Andrews was working on a legal treatise, on an unknown subject. ${ }^{76}$ Five years later, he published the first edition of a lengthy work under the title: American Law: A Commentary on the Jurisprudence, Constitution and Laws of the United States. ${ }^{77}$ Although criticized for failing adequately to cover criminal law and other topics, the book was generally praised for its attempt to organize and classify the body of American law, which critics of the case method saw as giving law students "the entire legal structure in all its completeness, symmetry and beauty.",78

In 1902, at the end of his first year as chair of the Classification Committee, Andrews delivered a fifty-page report on "the vocation of legal classification." He described the report as suggesting "the salient features and controlling points of what must ultimately constitute the scheme of legal classification." 79 The vocation of legal classification was:

1. To bring to the surface the fundamental principles of our law and organize them into a system.

\footnotetext{
${ }^{74}$ Id.

75 James DeWitt Andrews, Legislative Theories against Judicial Practice in Law Reforms, 3 AM. LAW. 393,396 (1895).

76 James DeWitt Andrews, 27 CHI. LEGAL NeWs 175, 175 (1895).

77 JAMES DEWITT ANDREWS, AMERICAN LAW: A COMMENTARY ON THE JURISPRUDENCE, CONSTITUTION AND LAWS OF THE UNITED STATES (1900). A second two-volume edition was published in 1908. In 1986 Robert Bone saw Andrews's treatise as "[p]erhaps one of the most ambitious contributions to the treatise writing tradition" and an example of treatises "inspired by a deep-seated belief in the existence of discoverable principles implicit in the evergrowing corpus of judicial decisions." Robert G. Bone, Normative Theory and Legal Doctrine in American Nuisance Law: 1850 to 1920, 55 So. CAL. L. REV. 1101, 1113 n. 14 (1986). For discussion of late nineteenth century authors' "approaches to identifying the general principles and concepts," see id. at 1115 n.18.

78 See e.g., Book Review, 33 CHI. Legal News 63, 63 (1900); Andrews' American Law, 34 AM. L. REV. 930,932 (1900) ("We are not sure that it is not the best classification of which the subject is capable."); Book Review (The Brief), supra note __ at 238 (("He has shown rare skill in arranging in logical, analytical form our American law as nearly as the state of things allows..."); Book Review, 14 HARV. L. REV. 392, 393 (1901) ("[Classification] is the first and most indispensable requisite of any treatise on the corpus juris. The classification adopted is in the main desirable and well-considered ...."); Book Review, 1 COLUM. L. REV. 137, 138 (1901) (Despite "grave defects in plan and execution," the work was "the first serious attempt which has been made on this side of the Atlantic at a complete classification of our legal system; and ... must be conceded to rank as a real achievement.").

In his Preface to the second edition, Andrews found that general approval of the plan of classification used in the first edition had affirmed that "the principle underlying it is the true one." Preface, JAMES DEWITT ANDREWS, AMERICAN LAW: A COMMENTARY ON THE JURISPRUDENCE, CONSTITUTION AND LAWS OF THE UNITED STATES v, v (2d. ed. 1908). In a review of the new edition, however, Roscoe Pound found that Andrews's "legal and political philosophy is thoroughly and frankly eighteenth century." R.P. [Roscoe Pound], Book Review, 2 ILL. L. REV.484, 485 (1908).

${ }^{79}$ Transactions of the Twenty-Fifth Annual Meeting of the American Bar Association, 25 ANN. REP. A.B.A. 3 , 22 (1902).
} 
2. To make the law more easily ascertainable (knowable).

3. To make it more certain and clearly stated.

4. To introduce a tendency toward uniformity which will ultimately result in practical uniformity.

5. A condensation and reduction in the bulk of expressed law.

6. To reduce the mass of statutes, decisions, constitutional rules and principles to a tangible, organized, manageable body. ${ }^{80}$

The report discussed a range of matters related to classification, each section bolstered by long quotations from works of earlier writers. ${ }^{81}$ The first section suggested that "the greatest impediment to progress in Jurisprudence consists in the failure to appreciate the importance of a scientific system of legal classification," 82 then argued for uniformity in the law. ${ }^{83}$ The answer to the problem was classification, the chief aim of which was: "the statement of the leading principals [sic], applicable to every department of law." ${ }^{24}$ Then came a discussion of the principles and rules of classification, ${ }^{85}$ and a comparison of schemes for organizing the subject of Law into categories either of Public Law and Private, or of Persons, Things, and Actions. The last pages of the report followed James Wilson in using the second approach to demonstrate a partial classification of the topic of Real Property. ${ }^{86}$ On the floor Andrews suggested that the committee had agreed only on "one proposition, namely, the importance of classification," but he hoped that it would "another year" submit "a scheme of classification" for adoption or rejection." 87

Nonetheless, the Classification Committee made no reports until 1905 when Andrews offered only an oral report which concluded that the Committee had accomplished little in the sixteen years since it was established in response to Terry's letter. The ABA did not have the resources to carry out a classification project, and neither the bar nor the teachers of law had shown active interest in the matter: "I think it may be said that they do not fully perceive the intimate relations between classification of law and the primary, paramount object of this Association, namely the

\footnotetext{
${ }^{80}$ Report of Committee on the Classification of the Law, 25 ANN. REP. A.B.A. 425, 426 (1902).

${ }^{81}$ Nearly all of Andrews's writings relied on lengthy quotations, usually without comment or analysis. A reviewer of his American Law treatise noted: "Professor Andrews has a fondness for making extended quotations from other authors, and also largely from after-dinner speeches, political addresses, etc." Book Review, 3 BRIEF 237, 237 (1900); a reviewer of the second edition found that Andrews "has strewed such a number of quotations through his chapters that they make the reading harder and the book heavier than is convenient or necessary." Book Review, 42 AM. L. REV. 797, 797 (1908).

${ }^{82}$ Report of Committee on the Classification of the Law (1902), supra note 80 at 428.

${ }^{83} \mathrm{Id}$. at $429-35$

${ }^{84} \mathrm{Id}$. at $450-51$.

${ }^{85} \mathrm{Id}$. at $455-62$.

${ }^{86} \mathrm{Id}$. at $474-75$.

${ }^{87}$ Transactions of the Twenty-Fifth Annual Meeting, supra note 79 at 22-23 (comments of James DeWitt Andrews).

The report itself urged the committee members to put forth greater effort during the coming year:

The views expressed have not had such consideration from all the members of the committee as to enable them to make a recommendation approving the positions advanced. It is desirable that the members give to the subject such consideration as will enable them to act on the recommendation of some plan of Legal Classification.

Report of Committee on the Classification of the Law (1902), supra note 80 at 473.
} 
promotion of jurisprudence; ... until we have a systematic body of law systematized we cannot have a jurisprudence." 88

Despite the profession's apparent failure to grasp that "classification is one of the essentials, if not the essential element of a highly developed jurisprudence," Andrews offered a resolution proposing that the matter be referred to a joint committee of the Special Committee on Classification and the standing Committee on Jurisprudence and Law Reform. The motion was adopted, ${ }^{89}$ but apparently received with little enthusiasm by the Committee on Jurisprudence. In 1906, that committee's report said simply that, because classification was a matter "peculiarly appropriate to the Committee on Classification of the Law [it] will be reported by that committee." 90 The Classification Committee itself offered no report then or in 1907. By 1908 it had been dropped from the list of ABA Committees.

In the meantime, the Committee on Law Reporting and Digesting regularly pressed for universal use of the classification system used in West's American Digest. ${ }^{91}$ In 1910, the committee praised West's system for its practical value, but also pointed out its limitations:

The digests that we have are merely alphabetical indexes of various topics of the law, with classification within the several topics, and cross references and tables of contents. They are arranged for the easy finding of cases on particular subjects and are well adapted to that purpose. A digest in the higher sense, a comprehensive statement in logical order of the whole body of the law as it exists today in the United States, we have not. ${ }^{92}$

\section{The Corpus Juris Project}

In February 1910 the lead article of The Green Bag devoted 30 pages to arguing the need for "a complete and comprehensive statement in adequate perspective of the entire body of American law," 93 followed by a plan for its creation and funding, and testimonials to the idea from prominent members of the bar. The Memorandum in re Corpus Juris was published under the name of Philadelphia attorney Lucien Hugh Alexander, ${ }^{94}$ but made clear that the plan was a "joint product"

\footnotetext{
${ }^{88}$ Transactions of the Twenty-Eighth Annual Meeting of the American Bar Association, 28 ANN. REP. A.B.A. 3 , 85 (1905). 
with Columbia law professor George Kirchwey ${ }^{95}$ and James DeWitt Andrews, who was now listed in Who's Who in New York as President and Managing Editor of Codex Publishing Co. ${ }^{96}$

In 1909, Alexander had called the second edition of Andrews's treatise on American Law "the greatest Commentary on our law, both national and state, that has yet appeared ...,"97 reserving his highest praise for Andrews's system for classifying the law, which followed the principles of classification suggested by James Wilson. ${ }^{98}$ For Alexander, Andrews's scheme also met Henry Terry's ideal of a system having both theoretical and practical value: "The scheme of classification would probably be regarded by theoretical jurists as its transcendent achievement .... On the other hand, practical jurists, like the late Austin Abbott, would doubtless see in the condensed style and the exactness of the definitions and the definiteness of the specific rules ..., its chief merit." 99

Alexander's Memorandum traced the need for a comprehensive statement of the law, quoting extensively from James Wilson, who was not only the first to call for an orderly statement of

\footnotetext{
${ }^{95}$ Memorandum in re Corpus Juris, supra note 93 at 59. Kirchwey taught law at Union College and at the Albany Law School, then at Columbia University from 1891-1916, where he was dean from 1901-1910, publishing books and articles on property law. After his deanship he became known as a criminologist and prison reformer, and was active in the American Peace Society. See Dr. Kirchwey Dies; Criminologist, 86, N.Y. TIMES, Mar. 5, 1942 , at 23. 96 See James DeWitt Andrews, 4 WhO's Who IN NeW YorK CiTY AND STATE 33 (1909).

${ }^{97}$ Lucien Hugh Alexander, America's Greatest Institutional Treatise, 21 GREEN BAG 104, 106 (1909).

${ }^{98}$ Id. at 106-07. Like Andrews, Alexander admired Wilson's contributions to American law and believed that he was underappreciated. Alexander had published a four-part "biographic" study of Wilson in the Green Bag. See Lucien Hugh Alexander, James Wilson-Nation Builder Part I, 19 GREEN BAG 1 (1907); Lucien Hugh Alexander, James Wilson-Nation Builder Part II, 19 GREEN BAG (1907); James Wilson-Nation Builder Part III, 19 GREEN BAG (1907); James Wilson-Nation Builder Part IV, 19 GREEN BAG 265 (1907). See also Lucien Hugh Alexander, James Wilson, Patriot, and the Wilson Doctrine, 183 NORTH AM. REV. 971 (1906), which Alexander himself called "propagandic." See Alexander, James Wilson-Nation Builder Part I, supra at 1, n.1. In his North American Review article, Alexander quotes a letter Wilson wrote to George Washington, in which he offered to prepare a digest of United States laws. See Alexander, Wilson, Patriot, supra at 6, quoting Letter from James Wilson to George Washington, Dec. 31, 1791.

${ }^{99}$ Alexander (1909), supra note __ at 108. The review ended with a long quotation from an 1889 speech by James C. Carter to the Virginia State Bar Association. Since both Alexander and Andrews regularly relied on lengthy quotations to support their arguments, it is worth noting how in this case Alexander seemed to misrepresent Carter's comments. In light of Carter's well-known opposition to codification of the law, the published quotation surprisingly reads in part:
}

A statement of the whole body of the law in scientific language, and in a concise and systematic form, at once full, precise, and correct would be of priceless value. It would exhibit the body of the law so as to enable a view to be had of the whole, and of the relation of the several parts and tend to establish and make familiar a uniform nomenclature. Such a work, well executed, would be the vade mecum of every lawyer and every judge. Alexander, America's Greatest, supra note 97 at 110 (italics in Alexander's version).

According to the Virginia Law Journal, however, what Carter actually said was:

A statement of the whole body of the law in scientific language, and in a concise and systematic form is precisely what is understood by a good Digest; and such a work, at once full, precise, and correct would be of priceless value. It would not indeed supersede special treatises upon the different branches of the law, or the books of report; but it would, by facilitating, save labor. It would refresh the failing memory, reproduce in the mind its forgotten acquisitions, exhibit the body of the law so as to enable a view to be had of the whole, and of the relation of the several parts, and tend to establish and make familiar a uniform nomenclature. Such a work, well executed, would be the vade mecum of every lawyer and every judge.

James C. Carter, The Provinces of the Written and the Unwritten Law, 13 VA. L.J. (Supp.) 1, 31 (1889) (italics added to show text deleted without indication by Alexander). 
American law, but despite dying before progressing far was "the only one who has attempted it on a complete and sufficiently comprehensive scale." 100 The later works of Story and Kent were incomplete and lacked the logical arrangement prescribed by Wilson. Andrews's own treatise on American Law, was "of course too condensed" to approximate what Wilson and others hoped for, but his "real achievement [was] his practical application to our law as a whole of a logically coordinated system of classification." 101 Relying heavily on lengthy quotations from prominent attorneys, judges, and law professors, Alexander argued that the need for a comprehensive statement of the law could not be met by specialized treatises or digests. ${ }^{102}$

The second part of the Memorandum described the plan that Alexander, Andrews, and Kirchwey had devised "to block out ... the entire field of the law under a logical system of classification," "103 calling for a seven-person board of editors ("the ablest to be found in America") who would have full control over editorial matters; several of their number would devote their entire time to the work. After the board of editors had outlined a system of classification, an associate board of editors made up of about twenty law professors would examine the classification, suggest revisions, and eventually write the text, which would be subject to final review by the board of editors. An advisory council made up of up to "twenty-five of the strongest men in the profession, both on the Bench and at the Bar" would offer advice to members of the associate board, and a larger board of criticism would review proofs in areas where they held expertise. ${ }^{104}$ " [T] he finished work ... must not be a composite of disjointed branches of the law treated by particular individuals, but a coordinated whole ...under final and authoritative centralized control." 105 Properly done, it could be completed in twenty volumes of one thousand pages. ${ }^{106}$

The final section eschewed commercial publication as a means to finance the project, instead urging establishment of a Foundation of Jurisprudence funded by "some man of large means anxious and able to use part of his wealth in benefiting mankind" or willing to entrust his funds to trustees to manage the project and ensure that his investment was returned. ${ }^{107}$ The Memorandum

\footnotetext{
${ }^{100}$ Memorandum in re Corpus Juris, supra note 93 at 63. The frontispiece to the February1910 Green Bag was a portrait of Wilson titled: "The First Great American Lawyer to Plan a Statement of our Corpus Juris." 22 GREEN BAG [ii] (1910).

${ }^{101}$ Memorandum in re Corpus Juris, supra note 93 at 64.

${ }^{102}$ Id. at 68-69, quoting "the ablest Judge west of the Mississippi" for the comment: "The whole analysis and arrangement of the body of our law has fallen into commercial and incompetent hands." Id. at 69.

${ }^{103} \mathrm{Id}$. at 71 .

${ }^{104} \mathrm{Id}$. at 74.

105 Id. at 73 .

106 Id. at 79 .

${ }^{107} \mathrm{Id}$. at 81 . The published version of the Memorandum dismissed the possibility that the Carnegie Institution might finance the project, while questioning the importance of some recent Carnegie-funded projects. See id. at 88-89. In September 1909, however, Alexander had sent a draft of the Memorandum to Roscoe Pound, noting: "The first thing of importance is of course the securing of the Foundation of Jurisprudence," and urged Pound to express his own views quickly and to emphasize the importance of establishing the Foundation. Letter from Lucien H. Alexander to Roscoe Pound (Sept. 1, 1909) (copy on file with author). A week later, he again asking Pound to write soon since he and his colleagues were about to submit a proposal for funding the foundation to "some member of the 'philanthropic phalanx." Letter from Lucien H. Alexander to Roscoe Pound (Sept. 8, 1909) (copy on file with author). On the $13^{\text {th }}$, Alexander wired Pound ("An immediate letter however short will be ten fold [sic] more valuable now than later.") then wrote to say "we are on the point of making an application for a Foundation to Mrs. Sage or Carnegie, and expect to close it out this week ... . " Letter from Lucien H. Alexander to Roscoe Pound (Sept. 13, 1909) (copy on file with author).
} 
closed by describing the benefits that would accrue from a million dollar gift to the foundation, followed by testimonials to the value of the project from prominent attorneys and judges, including three justices of the Supreme Court, and three law school deans. ${ }^{108}$ In the same issue, the editor of the Green Bag praised the project and the qualifications of its three initiators, ${ }^{109}$ while emphasizing the need for a lay philanthropist to come forward to fund the proposed Foundation of Jurisprudence to carry forth the work. ${ }^{110}$

Other journals soon commented on the proposal, mostly praising its ambition and endorsing the need it identified. ${ }^{111}$ One early note of criticism came in the February Bench and Bar, which noted the difficulties ahead, and found the estimate that the work could be completed in twenty 1,000 page volumes to be "wholly fallacious." 112 In May, the Green Bag published an article which compared the American Corpus Juris project to the existing American and English Encyclopaedia of Law, "whose value to the profession can hardly be estimated," and found it "entirely inaccurate and misleading to speak of [the new proposal] as "The American Corpus Juris." 113 Instead of yet another encyclopedia or digest, what was needed to promote uniformity was "a comprehensive and typical code of state law," that each state could review and adopt on its own. ${ }^{114}$

The harshest early commentary of the proposal was delivered by John Wigmore, dean of Northwestern Law School, who had published his classic treatise on the law of evidence a few years earlier. ${ }^{115}$ The Memorandum had cited Wigmore (along with the late James Barr Adams of

In June1910 the Philadelphia Inquirer reported that Alexander and others had presented the plan to an associate of John D. Rockefeller. See Thomas F. Logan, Behind the Scenes at the Nation's Capital, PHILADELPHIA INQUIRER, June 10, 1910, at 8, 8. Pound's undated endorsement was published with the Memorandum in the February Green Bag. See Opinions upon the Corpus Juris Project, 22 GREEN BAG 91, 105 (1910).

${ }^{108} \mathrm{Id}$.

109 The Editor's Bag, 22 GREEN BAG 138, 139 (1910) (Alexander "unites with the physique of an athlete the clear mind of a scholarly thinker and the executive ability of a magnetic and indefatigable organizer"; Andrews "is a jurist of remarkable powers of analysis, classification, and exposition, a master of the science of jurisprudence"; Kirchwey "is admirably qualified for editorial duties requiring extensive knowledge of the work of the country's ablest law professors and writers").

${ }^{110} I d$. at 138 .

${ }^{111}$ Much of the commentary was published in edited summary form in the August issue of the Green Bag. See American Editorial Comment Upon the Corpus Juris Project, 22 GREEN BAG 457 (1910).

112 The American Corpus Juris, 20 BENCH \& BAR 43, 45 (1910). Portions of the article (without the criticisms) were reprinted at American Editorial Comment, supra note 111 at 463.

${ }^{113}$ Hannis Taylor, The Unification of American Law, 22 GREEN BAG 267, 270 (1910). For an introduction to the elements of the Roman Corpus Juris Civilis, see Frederick W. Dingledy, The Corpus Juris Civilis: A Guide to Its History and Use, 35 LEGAL REFERENCE SERV. Q. 231 (2016)

${ }^{114} \mathrm{Id}$. at 272. Unlike digests, legal encyclopedias provide a measure of explanatory text along with summaries of individual cases and citations. See generally FREDERICK C. HICKS MATERIALS AND METHODS OF LEGAL RESEARCH WITH BIBLIOGRAPHICAL MANUAL 232-36 (1923). Edward Thompson Company's American and English

Encyclopedia of Law in 1887 was the first to take on the specific problems facing late nineteenth century American lawyers. Id. at 240-43.

In 1908 Andrews had sharply criticized legal encyclopedias as "nothing but topical texts made up of monographs, large or small, arranged alphabetically" at a meeting of the American Association of Law Libraries, arguing that, because of their arrangement, the encyclopedias added "not a single thought to jurisprudence." Worse, because alphabetical arrangement lacked principle and obscured relationships among its topics, it "has rendered our law chaotic. It has almost eradicated jurisprudence from American law." James DeWitt Andrews, The Use of the Law Library, 2 LAW LIBR. J. 8, 12 (1909).

115 JOHN HENRY WigMORE, TREATISE ON THE SYSTEM OF EVIDENCE IN TRIALS AT COMMON LAW (4 vol. 19041905). 
Harvard) as the type of person needed to serve on the board of editors for the Corpus Juris project. ${ }^{116}$ But, in a May 10 letter to the editor of the Green Bag, Wigmore registered his "emphatic dissent" to the project in hopes of "doing my small share to save the supposed benefactor from wasting ... his money on it." Wigmore found the proposal to be untimely because the "law is passing through a period of radical changes"; unsound because the law of the states varied "at countless points and in infinite details"; and futile because "there are not yet scholars enough to produce such a work equal to the ideals set forth." He closed by suggesting that his opinion was shared by "several well-known legal thinkers, and that he was moved to make public his thoughts "only by a sense of respect for the scientific needs of our law."117

Wigmore's letter was published in the July issue of the Green Bag, along with responses by Alexander and editor Arthur Spenser. Alexander criticized Wigmore for "preaching a gospel of despair" in the face of current problems, which if not resolved by this generation would burden future generations. ${ }^{118}$ Citing comments from foreign jurists and quoting at length from German law professor Heinrich Brunner he argued that the new Corpus Juris was necessary to demonstrate the vitality of American law and make clear that it was not merely a dialect of English common law. ${ }^{119}$ Spenser responded directly to each of Wigmore's objections, relying heavily on the comments from prominent lawyers published in the February issue in the February issue. ${ }^{120}$

In May, prior to the July publication of Wigmore's letter, but around the time it was received by Alexander, the Yale Law Journal published an article by Andrews under the title: The Next

${ }^{116}$ Memorandum in re Corpus Juris, supra note 93 at 71.

${ }^{117}$ Letter from John H. Wigmore to the Editor of the Green Bag (May 10, 1910), 22 GREEN BAG 428, 428 (1910). Andrews had antagonized Wigmore with his comments at the 1906 ABA annual meeting during a dispute over Roscoe Pound's address on "The Causes of Popular Dissatisfaction with the Administration of Justice." See Roscoe Pound, The Causes of Popular Dissatisfaction with the Administration of Justice, 29 ANN. REP. A.B.A. 395 (1906). At issue was whether Pound's talk should be published immediately as a pamphlet, prior to official publication in the proceedings of the 1906 meeting. As described by Hull, Andrews "claimed that [Pound's formulation] would undermine the common law as the lawyers knew it." Hull, RoscoE POUND AND KARL LLEWELLYN, supra note 8 at 65. Thirty years later in the introduction to a republication of Pound's address, Wigmore mocked Andrews and others who blocked its publication. See John H. Wigmore, Roscoe Pound's St. Paul Address of 1906: The Spark that Kindled the White Flame of Progress, 20 J. AM. JUD. SoC. 176, 177 (1937). For another account of the episode, also finding humor in Andrews's performance, see Report of the Committee on Judicial Administration and Remedial Procedure, 30 ANN. REP. A.B.A. 505, 505-506 (1907) (describing Andrews's detailed history of legal procedure "through the several stages of civilization"). See generally, Arthur L. Harding, Professor Pound Makes History, in The Administration of Justice In RETROsPeCt 3 (1957); DAVID Wigdor, Roscoe Pound: PHILOSOPHER OF LAW 123-30 (1974); PAul SAYRe, The LifE OF RosCOE POUND 146-51 (1948).

Pound's address drew explicitly from Wigmore's evidence treatise. See Letter from Roscoe Pound to John Wigmore (Nov. 10, 1906) (noting that "the inspiration and a great deal of the actual material" were taken from the treatise) (Wigmore Papers, Series 17, Box 20) (copy on file with author). See ANDREW PORWANCHER, JOHN HENRY WIGMORE AND THE RULES OF EVIDENCE 137-46 (2016) regarding the long professional and personal relationship between Pound and Wigmore. See also Hull, RoscoE POUND AND KARL LlEWEllyn, supra note 8 at 79-81 for a discussion of their later dispute regarding the AALS Modern Legal Philosophy Series.

${ }^{118}$ Letter from L.H.A [Lucien Hugh Alexander] to the Editor of the Green Bag (May 13, 1910), 22 GREEN BAG 428 , 428 (1910). In August 1910, Alexander sent Roscoe Pound reprints of Wigmore's letter and his own "little reply which is far from what it ought to be and was dashed off on same day I received copy of Wigmore's letter." Letter from Lucien H. Alexander to Roscoe Pound (Sept. 10, 1910) (copy on file with author).

119 See Letter from L.H.A [Lucien Hugh Alexander], supra note 118 at 429-30.

120 The Editor's Bag, 22 GREEN BAG 420 (1910). 
Great Step in Jurisprudence. ${ }^{121}$ Although Andrews did not mention Wigmore, parts of his article seemed to anticipate Wigmore's concerns. Andrews acknowledged that "[e]xternally the laws of the various States seem to present a medley of contradictions, a chaotic assortment of incongruous ideas," but argued that, while "there is still some conflict upon minor points, ... the fundamental questions of our law are so well settled and so generally understood as to be ready to yield to the sifting of science for the purpose of logical organization and exposition." 122 In addition, he argued that the work could present a more complete treatment in twenty volumes than in forty, as long as the text were carefully, written, and edited, and citations were "not padded with a mass of cases." 123

The classification needed to be inductive - "drawn from the detailed examination of typical elements of every part of our law." As an illustration, Andrews cited the classification he had prepared for the ABA Committee on the Classification of the Law in 1902, which he had put to practical use in his own treatise on American law. ${ }^{124} \mathrm{He}$ admitted, though, that individual effort could not construct a full statement of the Corpus Juris: "The work cannot be and should not be the work or one man, nor should any one man assume to dominate any part of it." ${ }^{\prime 25}$

In August the Green Bag compiled excerpts from positive commentary on the project published in general journals and newspapers. ${ }^{126}$ In the same issue, Arthur Spencer described the opinions of leading jurists published in February "as perhaps the most remarkable collection of comments on any legal proposition that have ever been got together." ${ }^{27}$ Ignoring Wigmore's criticisms, which he had published only one month earlier, he went on to conclude that "[w]hatever slight opposition may have since developed among lawyers has been vague, inarticulate, and negative." 128

The following month, more than twenty years after he had first raised the matter of classification to the ABA, the Green Bag published an article by Henry Terry on The Arrangement of the Law, ${ }^{129}$ which focused on what he termed "a natural arrangement of the law." 130 This required identifying the fundamental conceptions on which the law is based, which for Terry were three: rights, duties, and wrongs. ${ }^{131}$ Most of the article was written to support this argument; the last pages provided his outline of private substantive law. ${ }^{132}$ An editor's note pointed out that readers should not assume that the article represented the views of the sponsors of Corpus Juris

\footnotetext{
${ }^{121}$ Andrews, Next Great Step, supra note 69 at 486 . The article was excerpted in the July issue of the Green Bag which included Wigmore's letter and the responses from Alexander and [the editor]. See The Next Great Step in Jurisprudence, 22 GREEN BAG 405 (1910).

${ }_{122}$ Andrews, Next Great Step, supra note 69 at 488.

${ }^{123} \mathrm{Id}$. at $502-03$.

${ }^{124}$ Id. at 501, citing Report of Committee on the Classification of the Law (1902), supra note 80.

${ }^{125}$ Andrews, Next Great Step, supra note 69 at 504.

${ }^{126}$ American Editorial Comment, supra note 111 at 457.

127 The Editor's Bag, 22 GREEN BAG 485, 485 ((1910).

${ }^{128} I d$.

${ }^{129}$ Henry T. Terry, The Arrangement of the Law, 22 GREEN BAG 499 (1910).

${ }^{130} I d$. at 499.

${ }^{131} I d$. at 508 .

${ }^{132} I d$. at 509 .
} 
Project and that in the next issue Andrews would publish a paper "expressive of his views upon the classification of the law."133

In his September article, as elsewhere, Terry referred to arrangement of the law, rather than to classification. ${ }^{134}$ In October, Andrews made clear his view that classification was the basis of the science of jurisprudence as well as for other sciences. ${ }^{135} \mathrm{He}$ offered an implicit response to Terry's concerns about the arbitrariness of divisions by arguing that definition is an essential element of classification because it provides "discrimination of related ideas in such a way that differences in their natures are made plain." "136 Andrews also emphasized the importance of clarifying what was being classified: "Are we attempting to classify the Rights secured by law, or the Laws by which these rights are defined and protected?" In either case, "we are not endeavoring to arrange the body of our law [but] attempting to classify the parts of our law and build them into a systematic body." Because laws encompass more than rights, "[w]e are attempting to classify laws. That is to say: To arrange the specific rules of law so that they shall appear in a natural order according to some principle of communication." 137 Thus, the fundamental elements of law were not rights, duties, and wrongs as Terry believed, but rather leading ideas, principles, and rules. "[U]nder such divisions all the elements of a given body of law can be grouped." ${ }^{38}$ The rest of the article discussed divisions suggested by earlier writers, and the need for systematic classification to precede codification.

In September, the ABA Committee on Law Reporting and Digesting discussed the Corpus Juris project, as well as Wigmore's objections, describing the proposal as a "digest in the higher sense," too large a subject to come under its jurisdiction. The committee said only that "the making of such a digest would change profoundly the conditions of reporting and digesting in the future, and the plan is a matter of great interest in connection with this whole subject, and we cannot fail to mention it in our report.",139

In October the project was severely criticized in the Illinois Law Review by Joseph Kelly, who questioned whether it was appropriate to compare it to Justinian's Corpus Juris Civilis. ${ }^{140}$ Kelly saw Alexander's Memorandum not as a plan for an American Corpus Juris, but only "a plan of control." It did not specify a scheme of classification ${ }^{141}$ and seemed to be intended as either a

\footnotetext{
${ }^{133}$ Id. at 499. Alexander forwarded a pre-publication copy of Terry's article to Pound and alerted him to Andrews's upcoming article, making it clear that Andrews's piece "will represent Andrews' view only and in no sense be expressive of the views of either Kirchwey or myself." He then asked: "Won't you follow up (in the November issue if possible) with your own views on the subject?" Alexander noted the value of thrashing out the subject "in advance of the assembling or even selection of any Corpus Juris editors." Letter from Lucien H. Alexander to Roscoe Pound (Aug. 19, 1910) (copy on file with author). In October Alexander repeated his request, asking that Pound outline his "present views" on classification in either the Green Bag or the Harvard Law Review. Letter from Lucien H. Alexander to Roscoe Pound (Oct. 17, 1910) (copy on file with author).

${ }^{134}$ See supra, text accompanying note

${ }^{135}$ See Andrews, Next Great Step, supra note 69 at 489 ("The talisman, the touchstone, the guiding principle in this science as in every other, is analysis and classification.").

136 James DeWitt Andrews, The Classification of Law, 22 GREEN BAG 556, 557 (1910).

${ }^{137}$ Id. at 559

${ }^{138} I d$. at 560.

${ }^{139}$ Report of the Committee on Law Reporting and Digesting (1910), supra note 92 at 535.

140 Joseph I. Kelly, The American Corpus Juris Project: Its Relation to a Foundation for the Advancement of Jurisprudence and to the Future of American Law, 5 ILL. L. REV.129, 134 (1910) ("Beyond the system of control, the project has no objective plan.").

${ }^{141} I d$. at 136.
} 
twenty volume edition of Andrews's American Law or a new form of digest or encyclopedia, ${ }^{142}$ offering nothing to distinguish it from those already available. ${ }^{143}$ The idea for a Foundation for the Advancement of Jurisprudence seemed to have been tacked on merely as an afterthought. Although such a Foundation "untrammeled by any such immature and ill-considered project, cannot be too warmly advocated," 144 the Memorandum "inverts the order of time and the relative importance of an 'institutional digest' and the Foundation for the Advancement of Jurisprudence." 145 Because it neither presented a classification, nor tasked the Foundation with developing one, Kelly inferred that the project intended to employ the classification of Andrews's American Law. ${ }^{146}$

Others cited Kelly's article to bolster their own criticisms of the project. In January 1911 Law Notes alluded to Kelly in a short comment under the title: "Has Anybody Here Seen American Corpus Juris?" and predicted "it will not be long before the project becomes completely devoid of seriousness." 147 In July the Annual Bulletin of the ABA Comparative Law Bureau noted Kelly's "exceptionally able and interesting critique" of the Corpus Juris Project, and "eloquent and persuasive plea for a Foundation for the Advancement of Jurisprudence in lieu thereof."148

In January 1912 Bench and Bar expressed doubts about the need for such project in light of the "wonderful digests of the West Publishing Company" and existing legal encyclopedias, ${ }^{149}$ and questioned its financial viability. Quoting a newspaper estimate that $\$ 100,000$ would be raised to carry on the Academy's business and establish the publishing company, the article suggested that the amount might be sufficient to cover perhaps five of what it saw as the fifty or more volumes the work would require, and warned potential supporters to proceed cautiously. ${ }^{150}$

In an April 1912 article on German jurisprudence, Frank Borchard noted that "the project of the American Corpus Juris has enlisted much popular support.... yet one of our foremost jurists, Wigmore, has expressed grave and pertinent doubts as to its timeliness, its soundness, and its feasibility." "151 It was significant for Borchard that "American lawyers are almost wholly untrained in that technique of legal science which must precede any attempt at systematic statement of the

\footnotetext{
${ }^{142}$ Id. at 135 .

${ }^{143}$ Id. at 137,141 . Rather, he found: "Generalities are redundantly present." Id. at 137.

${ }^{144} \mathrm{Id}$. at 141 .

${ }^{145} \mathrm{Id}$. at 150 .

${ }^{146} \mathrm{Id}$. at 151 ("in their infatuation for a particular scheme, the triumvirs deny the Foundation any function of its own" (citing Alexander, America's Greatest Institutional Treatise, supra note 104)).

None of the three primary proponents of the February Corpus Juris proposal responded in print to Kelly. After his Memorandum was published in February, Alexander wrote nothing beyond his response to Wigmore's criticisms in the Green Bag; Andrews published articles in the Yale Law Journal and in the Green Bag, but made no direct response to Kelly. George Kirchwey seems to have made no public comments on the project, although he published a speech on the inflexibility of the legal system in July. See George W. Kirchwey, Respect for Law in the United States, 36 ANNALS OF THE AMERICAN ACADEMY OF POLITICAL AND SOCIAL SCIENCE 212 (1910).

${ }^{147}$ Has Anybody Here Seen American Corpus Juris? 14 LAW Notes [Edward Thompson Co.] 183, 183 (1911).

${ }^{148}$ Editorial Miscellany, 4 ANN. Bull. [Comparative Law Bureau of the American Bar Association] 11, 14 (1911).

149 “To Harmonize the Legal Systems of the States,” 28 BENCH \& B. (o.s.) 36, 36 (1912). See also R.H.G., Harmonizing State Laws, 3 J. AM. InST. CRIM. L. \& CRIMINOLOGY 113 (1912).

${ }^{150} \mathrm{Id}$.

${ }^{151}$ Edwin Borchard, Jurisprudence in Germany, 12 Colum. L. Rev. 301, 303 (1912).
} 
law. Our law has grown up so rapidly and so heterogeneously that it is almost impossible now, in many of its branches, to find any thread of legal principle." 152

In its issue for May-June 1912, the American Law Review offered a detailed critique of the Corpus Juris proposal, finding startling the claim that only James Wilson had undertaken a similar project in light of the fact that two private publishers had each developed encyclopedias claiming to cover all American law under a logical system of classification. ${ }^{153}$ It went on to suggest that anyone who thought that a comprehensive statement of the body could be published in only twenty volumes was either "sublimely ignorant of the practical side of legal publishing or is trying to mislead ... . Perhaps Mr. Andrews does not understand the meaning of Corpus Juris."154

Noting that original Memorandum had pointed out the need for "highly centralized executive and editorial control," which "needless to add" would be provided by Alexander, Andrews and Kirchwey, the article looked at the qualifications of each for the task. Although Alexander and Kirchwey had reputable backgrounds, neither offered much experience for so large an undertaking. Andrews, on the other hand, had chaired the board of editors of the short-lived "Case Law and Index" series, which had delivered only one of a projected sixty volumes, and was "a monstrosity in legal literature for the existence of which no justification or excuse has ever been discovered . . .."155 The article was equally critical of Andrews's American Law, quoting liberally from a review of the first edition that pointed out the book's lack of proportion, the writer's lack of style, and substantive errors, before concluding: "That any considerable number of people, law students or lawyers, should actually read it, is inconceivable. ${ }^{156}$ The article suggested that the critical review had been written by Andrew's partner in the Corpus Juris Project, George Kirchwey. ${ }^{157}$

After reminding its readers of the criticisms made by Wigmore and Kelly, the article finished by questioning the immediate need for the project and again challenging the qualifications and plan of the present proponents. The job could be done only by an organized staff of jurists and professional writers like those who had prepared other successful encyclopedias. ${ }^{158}$

In August 1912, Roscoe Pound told the AALS that an obstacle to the progress of the law was "our lack of a system of the law as a whole," while echoing Wigmore's concerns that in a period of "prodigious legislative activity, in which legislation is making over, or attempting to make over, or at least to restate, whole departments of the law . . . the attitude of our taught tradition toward this new element of the law is a matter of grave concern." ${ }^{159}$ But, by this time, Andrews had already moved on to organize a new proposal through the American Academy of Jurisprudence.

\footnotetext{
${ }^{152}$ Id. at 303-04.

153 The Proposed American Corpus Juris, 46 AM. L. REV. 437, 438 (1912). The article was quickly reprinted in two West journals. See American Corpus Juris, 1 Docket (West Pub. Co.) 765, 771 (1912); Notes and Personals, 3 AM. L. SCH. REV. 218 (1912).

${ }^{154}$ Proposed American Corpus Juris, supra note 153 at 439.

155 Id. at 440. For more favorable reviews of the one published volume of Case Law and Index, see Reviews, 13 YALE L.J. 263 (1904); Journals and Books, 21 MEDICO-LEGAL J. 408, 415 (1904).

${ }^{156}$ Id. at 441 (quoting Book Review, 1 COLUM. L. REV. 137, 140 (1901)).

${ }^{157} \mathrm{Id}$.

${ }^{158}$ Id. at 442. At the time the article was published, American Law Book company's Cyclopedia of Law and Procedure (1901-1912) was the only currently-published American legal encyclopedia. See Hicks (1923), supra note 114 at 243.

${ }^{159}$ Roscoe Pound, President's Address, 12 A.A.L.S. Proc. 55, 72 (1912).
} 


\section{The American Academy of Jurisprudence}

\section{Announcement and Initial Responses}

In December 1911 the Associated Press reported that "an association to be known as the American Academy of Jurisprudence is in the process of formation," ${ }^{160}$ its aim being to make a "scientific and concise statement of the entire body of American law," published as a "Corpus Juris Codex." 161 Funding would come from up to 250 subscriptions or contributions from members of the bar and bench. ${ }^{162}$ Details, as well as a plan of operation, were provided in a pamphlet which proposed a corporation to create and publish the Codex (and other products), which would then be distributed and sold by "old line Publishing Houses, who have no encyclopadiae of their own."163

The pamphlet discussed the importance of scientific classification, closing with an argument that the work could be led "only by a man of peculiar ability and favored by peculiar conditions," such as James DeWitt Andrews, whose "range of research and scope of exposition [were] unequaled by any living jurist, and equaled by few of any age." "164 The last pages quoted glowing reviews of Andrews's American Law, and printed a letter of praise from Lucien Alexander, who emphasized Andrews's knowledge of James Wilson: "As the result of years of application, Andrews has perfected in detail a plan for a great system of American Jurisprudence, scientifically co-ordinated on the lines proposed by Wilson more than a century ago . . .."165

In the face of continuing criticism of the original Corpus Juris Project, ${ }^{166}$ in 1913 Andrews vetted the names of possible members of the American Academy of Jurisprudence with Roscoe Pound, ${ }^{167}$ William Howard Taft, and others. ${ }^{168}$ In July he sent a list of names to Pound, Taft (and

${ }^{160}$ For Uniform System, KANSAS CITY STAR, Dec. 15, 1911. See also To Harmonize Legal Systems of the States, Globe (New York City), Dec. 11, 1911.

161 Justinians of America, MACON TELEGRAPH, Dec. 20, 1911.

${ }^{162} \mathrm{Id}$.

163 THE AMERICAN ACADEMY OF JURISPRUdENCE: PlAN FOR ESTABLISHING IT THE CORPUS JURIS CODEX: PLAN FOR Creating It 5-7 [1911]. Like Alexander's Memorandum and the materials published in the 1910 Green Bag, much of the pamphlet was devoted to testimonials from prominent attorneys regarding the need for such a project.

${ }^{164}$ Id. at $23,24$.

${ }^{165}$ Letter from Lucien Hugh Alexander to Justice William H. Moody (Sept. 8, 1909), in AMERICAN ACADEMY OF JURISPRUDENCE: PLAN FOR ESTABLISHING IT, supra note 163 at 27.

166 See supra text accompanying notes 140-58.

167 Andrews's connections with Pound dated back at least to the controversy over publication of Pound's 1906 ABA address. See infra note 117. More recently, Andrews had sent Pound a complimentary handwritten note about Pound's article on liberty of contract, see Roscoe Pound, Liberty of Contract 18 YALE L.J. 454 (1909), in which he was "glad to observe that in my efforts to elucidate our law I do not fall within your strictures on text writers," and included citations to passages from his treatise on American law. He wished that Pound had discussed how Andrews treated some "fundamental questions" in his own treatise, but nonetheless felt that Pound had justified his own "somewhat advanced position." Letter from James D. Andrews to Roscoe Pound (Sept. 9, 1909) (copy on file with author).

168 After leaving the White House in March 1913, Taft accepted a position as Kent Professor of Law and Legal History at Yale Law School, which he held until being named Chief Justice of the Supreme Court in 1921. See generally LEWIS L. Gould, CHIEF EXECUTIVE TO CHIEF Justice: TAFT BETWIXT THE WHITE HOUSE AND SuPREME COURT (2014). None of his biographers, including those who focused on the period when was at Yale, discuss Taft's role with the American Academy. Taft's conservative positions on judicial reform are discussed in Peter G. Fish, William Howard Taft and Charles Evans Hughes: Conservative Politicians as Chief Judicial Reformers, 1975 SuP. CT. REV. 123, 124-30; and in DAVID H. BURTON, THE LEARNED PRESIDENCY 119-24 (1988). 
others), asking them indicate who should not be asked or whose invitation should be postponed for any reason. Although eventually membership would be limited to 250, "for the present the invitations will be to a much smaller number." 169 Taft quickly approved the list, ${ }^{170}$ but a September letter from Andrews to Pound suggests that Pound, Ezra Thayer, and Samuel Williston had hesitated to approve Andrews's friend Waldo G. Morse. ${ }^{171}$

In that letter, in addition to pushing for Morse's admission to the group, Andrews wrote: "You will be pleased to know that I had a most pleasant interview with Dean Wigmore and that he only waits [sic] the necessary formal approval of the signers before signing his name." ${ }^{172}$ In early November he pressed Pound to indicate his position on the remaining names and expressed his hope for an early meeting, asking Pound to suggest a suitable day in December. ${ }^{173}$ On November 26, Andrews informed Wigmore that he had been approved for membership in the Academy, including with the letter lists of the names of other charter members, a proposed act of

Taft became President of the American Bar Association in September 1913 five months before assuming the presidency of the American Academy of Jurisprudence. His ABA presidential address in 1914 did not mention matters relating to the Academy. See William Howard Taft, Address of the President, 37 ANN. REP. A. B. A 359 (1914). By the time his ABA term ended in October 1914, Taft was increasingly involved in activities leading to the formation in June 1915 of the League to Enforce Peace and his presidency of that organization, an office he held until 1921. See GOULD, supra at 44-49; BURTON, supra at 129-31.

${ }^{169}$ Letter from James D. Andrews to Roscoe Pound (July 11, 1913) (copy on file with author).

${ }^{170}$ Letter from William H. Taft to James D. Andrews (July 15, 1913) (Taft Papers Series 8 Reel 1) (Copy on file with author). In May Taft had provided Andrews a letter to present to Elihu Root. See Letter from William H. Taft to James D. Andrews (May 2, 1913) (Taft Papers Series 8 Reel 518) (Copy on file with author).

${ }^{171}$ Letter from James D. Andrews to Roscoe Pound (Sept. 15, 1913) (copy on file with author).

In 1912 Morse called for a scientific classification of the law as a solution to problems of uncertainty. See Waldo G. Morse, The Necessity for a Restatement of Our Law, 28 BENCH \& B. (O.S.) 82 (1912) (letter to the editors). In 1917 he privately published his own proposal. See WALDO G. MORSE, A STUDY IN LAW AND INDUCTION (1917).

Later he served as chair of a New York State Bar Association committee on classification and restatement, which included Andrews and Adolph Rodenbeck as members. In 1920, the committee offered a resolution urging cooperation on classification with other state bar associations. Report of the Committee on Classification of the Law, 43 N.Y. STATE BAR ASSOC. 94 (1920). In 1921 the committee reported that it had received favorable responses to its report from twenty-nine other associations, but in light of the ABA's approval of its own special committee's recommendations (see infra text accompanying notes 291-293), recommended that it do no more than cooperate with other state bar initiatives as they arose. Report of the Committee on Classification of the Law, 44 N.Y. STATE BAR ASSOC. 89 (1921). The committee offered several later reports, one of which focused on Morse's own classification system. See Report of the Committee on Classification of the Law, 46 N.Y. STATE BAR ASSOC. 146 (1923). See also Report of the Committee on Classification of the Law, 45 N.Y. STATE BAR ASSOC. 113 (1922); Report of the Committee on Classification of the Law, 47 N.Y. STATE BAR ASSOC. 82 (1924). In 1923 Morse delivered his paper The Law as a Science at a symposium on classification and restatement, which included papers by Harlan F. Stone, William Draper Lewis, and Karl Llewellyn. See Waldo G. Morse, The Law as a Science, 10 Proc. ACAD. POL. SCI. IN THE CITY OF NEW YorK 59 (1923).

${ }^{172}$ Letter from Andrews to Pound (Sept. 15, 1913), supra note 171.

${ }^{173}$ Letter from James D. Andrews to Roscoe Pound (Nov. 6, 1913) (copy on file with author). Pound's papers include an undated typewritten list of over sixty names, twenty-four of which (including Wigmore) had been proposed by Pound. Wigmore's name was also suggested by Ezra Thayer. For a similar letter and list, see Letter from James D. Andrews to William H. Taft (Nov. 6, 1913) (copy on file with author) (Taft Papers, series 3, Reel 132). Taft responded by stating his opposition to including William Draper Lewis. Letter from William $\mathrm{H}$. Taft to James D. Andrews (Nov. 8, 1913) ("I do not want to be associated in the question of jurisprudence with any man who favors a recall of judicial decisions ....") (Taft Papers Series 8 Reel 520) (Copy on file with author). 
incorporation, his pamphlet on Jurisprudence and another discussing the Academy and the Corpus Juris Project. ${ }^{174}$

\section{Organization and Wigmore's Opposition}

On January 28, 1914 Andrews notified the approved members of the Academy that an organizational meeting would be held in New York in February. ${ }^{175}$ Wigmore declined his invitation with an 8 page "circular letter" to 48 "signers of the 'Consent of Charter Members'."176 In declining, Wigmore expanded on some points in his 1910 letter to the Green Bag regarding the original American Corpus Juris proposal, again arguing that American law was undergoing "seething change," making it futile to state it in any durable form, particularly since in the United States there was as yet no real "understanding of analytic jurisprudence and philosophy of law." 177

But Wigmore also found the project to be ill-fitted to its purpose, which he took to be to write down the law and "to discuss and settle matters of general jurisprudence."178 Those on the list were "too much engaged in other duties" to devote time to this work and the list lacked the names of legal philosophers. "To get at the fundamentals of the law, for re-stating it, without the help of the philosophers, is to ignore the prime facts of the situation." 179 For Wigmore, an association such as the nascent Conference of Teachers of Law and Philosophy which had met the previous April in New York would be a better model. ${ }^{180}$

Wigmore's final, and most pointed, reason for declining to participate was that "the present proposed organization is not properly initiated." He noted that the pamphlets that came with the letter of solicitation carried Andrews's name which allowed the conclusion that "their learned author must in fairness be considered as the dominating spirit of the organization." For Wigmore, however, "the tenor of those pamphlets is such that American Legal Science cannot afford to let itself be represented by them ... they are musty of the past, - redolent of legal ideas which nobody else would think of advancing today." 181

Wigmore then closed with the following comments on Andrews:

\footnotetext{
${ }^{174}$ Letter from James D. Andrews to John H. Wigmore (Nov. 26, 1913) (Wigmore Papers, American Academy of Jurisprudence, 1913-1914 Box 247, Folder 1) (copy on file with author).

${ }_{175}$ See, e.g., Letter from James D. Andrews to Mr. Roscoe Pound (Jan. 28, 1914) (copy on file with author).

${ }^{176}$ See Letter from John Henry Wigmore to William Howard Taft, etc., enclosed in letter from John H. Wigmore to Roscoe Pound, Esq. (Jan. 28, 1914) (copy on file with author). Neither Lucien Alexander nor George Kirchwey were listed. See also Daniel R. Ernst, Book Review, 102 YALE L.J. 1019, 1019-20 (1993) and sources cited therein.

${ }^{177}$ Letter from Wigmore to Taft, etc., supra note 176 at 1-4.

178 Id. at 4.

${ }^{179}$ Id. at 4-5.

${ }^{180}$ Id. In April 1914 John Bassett Moore made similar comments regarding the possibilities of the New York conference. See John Bassett Moore, The Passion for Uniformity, 62 U. PA. L. REV. 525, 543-44 (1914) (suggesting that "reform in our legal conditions must be the work of students and philosophers rather than of politicians and practicing lawyers.").

${ }^{181}$ Letter from Wigmore to Taft, etc., supra note 176 at 6 . In a note, Wigmore wrote: "In this respect, be it noted, the learned author is chargeable with no more than being typical of ordinary American thought." Id. at 7, note 1. In Wigmore's papers, the copy of the pamphlet that discussed the plan for the Academy and the Codex project, the part of the title page mentioning the Codex and the paragraphs describing the Academy Publishing Company inside, are both crossed out.
} 
I take the liberty of saying that I have been acquainted for fifteen years past with the learned author of those pamphlets; that he has long possessed the conviction that his theory of law and legal classification is the only one meriting adoption in this country; that he has applied his powerful will and assiduous industry to obtaining that adoption; that he is in the above conviction profoundly wrong; that he is nevertheless entitled to that conviction as a personal possession; that he is further entitled to publish his system, and to let it be discussed and accepted or rejected by professional opinion; that I and all others are willing to see it prevail, if it can, after it has been subjected to public criticism on its own merits and on his individual responsibility for authorship; but that it is a mistake for him to attempt to secure beforehand an indorsement of his theories from a distinguished list of legal brethren who are good-natured enough to sign their names to a plan for a high-purposed Society; . . ${ }^{182}$

The responses to Wigmore's letter reveal the feelings of a number of those invited to the February meeting. At least fourteen of the recipients wrote back to Wigmore. Buffalo attorney Adelbert Moot found that Wigmore had "call[ed] a spade a spade in plain terms." 183 William Guthrie of New York confessed that he had allowed his name to be used because he "was afraid that it would look somewhat churlish to refuse." 184 James Beck of Shearman \& Sterling wrote that he assented to parts of Wigmore's letter, dissented from some, and found some to be "beyond my limited knowledge of the law."185

Boston lawyer Moorfield Storey had joined the Academy "not with the expectation that I should be able thereby to accomplish much in the way of affirmative action, but that I might be in a position to prevent action of which I did not approve . . . I I have never had any serious doubt that the enterprise would fail."186 Elihu Root urged Wigmore to join the Academy despite his doubts, although Root himself "had no idea of becoming part of a tail to Mr. Andrews's kite or of indorsing anybody's theories or anybody's attempt to put forth a new Corpus Juris Civilis." 187 Frederick Coudert also found Wigmore's refusal to participate to be unfortunate "as what we need now are views like your own."188

Emlin McClain wrote that, from his personal knowledge of Andrews he had "very little confidence in his ability to formulate a system of jurisprudence," but added his own name to the list because sometimes "a valuable movement may be initiated by persons not capable themselves

\footnotetext{
${ }^{182} \mathrm{Id}$. at 8. For Wigmore's approaches to classification, see John H. Wigmore, Terminology of Legal Science with A-Plea for the Science of Nomo-Thetics, 28 HARV. L. REV. 1, 3-5 (1914); John H. Wigmore, Nova Methodus Discendae Docendaeque Jurisprudentiae, 30 HARV. L. REV. 812, 821-22 (1917). See also PORWANCHER, supra note 117 at 97-99 ("Wigmore consistently championed the modernist view that legal principles, categories, and relations were socially constructed rather than natural and immutable." Id. at 97-98.

${ }^{183}$ Letter from Adelbert Moot to John H. Wigmore (Feb. 4, 1914) (Wigmore Papers, American Academy of Jurisprudence, 1914 Box 20, Folder 16) (copy on file with author).

${ }^{184}$ Letter from William D. Guthrie to John H. Wigmore (Feb. 4, 1914) (Wigmore Papers, American Academy of Jurisprudence Additions, 1913-1914 Box 247, Folder 1) (copy on file with author).

${ }^{185}$ Letter from James M. Beck to John H. Wigmore (Feb. 4, 1914) (Wigmore Papers, American Academy of Jurisprudence, Box 20, Folder 16) (copy on file with author).

${ }^{186}$ Letter from Moreland Storey to John H. Wigmore (Feb. 9, 1914) (Wigmore Papers, American Academy of Jurisprudence, 1914 Box 20, Folder 16) (copy on file with author).

${ }^{187}$ Letter from Elihu Root to John H. Wigmore (Feb. 9, 1914) (Wigmore Papers, American Academy of Jurisprudence, 1914 Box 20, Folder 16) (copy on file with author).

${ }^{188}$ Letter from Frederic R. Coudert to John H. Wigmore (Feb. 9, 1914) (Wigmore Papers, American Academy of Jurisprudence, 1914 Box 20, Folder 16) (copy on file with author).
} 
of carrying it to a successful conclusion." He disagreed with Wigmore that this was an inopportune time for systematic statement of the law, and hoped that something profitable might be done, but concluded: "I would not for a moment try to make myself a champion of Mr. Andrews and his scheme." 189

Wigmore received at least three replies from Harvard Law School. ${ }^{190}$ Ezra Thayer wrote that, by provoking Wigmore's comments (to which he offered no response), the Academy had justified itself beyond his expectations, and pointed out thus far it had "not yet committed itself to anything, and therefore not to codification or corpus juris nonsense." 191 Samuel Williston wrote that the Harvard faculty who joined the Academy had done so after being assured that it would have nothing to do with Andrews's corpus juris proposal or any other proposal to state the law. Because Taft and Root had already joined, the Academy was certain to be formed, whether or not he and others with doubts signed on, making it better for them to take part than to leave the project to Andrews and "people of eminence whose names would carry weight, but would give little thought to the matter." The Harvard professors had asked for veto power over all proposed members, something to which Andrews readily agreed. ${ }^{192}$

As Dean of the Law School, Roscoe Pound was clearly troubled by how Harvard should best respond to the Academy proposal. Although Andrews had already enlisted enough prominent lawyers to make the proposal "somewhat formidable" before they were asked to join, the Harvard professors at first "turned it down vigorously," but ultimately decided to participate, at least in part to avoid "the charge so often brought against Harvard of objecting to everything and taking part in nothing." 193 However, he wrote Wigmore that, if the project became a vehicle for "some impractical scheme for publishing a superfluous encyclopedia, you may be sure that we at Cambridge will have nothing to do with it." 194

\section{Meeting in February}

Despite Wigmore's opposition, on February 11 a formal announcement of the inaugural meeting, signed by Taft, Alton B. Parker, Root, Henry Wade Rogers, and Andrews, was sent out on the letterhead of The American Academy of Jurisprudence, ${ }^{195}$ and the meeting went forward as scheduled on February 21. The next-day edition of the New York Times featured interviews with Andrews and Alton Parker, and discussion of the Academy constitution, which was adopted at the

\footnotetext{
${ }^{189}$ Letter from Edwin McClain to John H. Wigmore (Feb. 9, 1914) (Wigmore Papers, American Academy of Jurisprudence, Box 20, Folder 16) (copy on file with author).

190 Wigmore's papers do not include a response from Joseph Beale.

${ }^{191}$ Letter from Ezra Thayer to John H. Wigmore (Feb. 5, 1914) (Wigmore Papers, American Academy of Jurisprudence, Box 20, Folder 16) (copy on file with author).

192 Letter from Samuel Williston to John H. Wigmore (Feb. 5, 1914) (Wigmore Papers, American Academy of Jurisprudence, Box 20, Folder 16) (copy on file with author).

${ }^{193}$ Letter from Roscoe Pound to John H. Wigmore (Feb. 5, 1914) (Wigmore Papers, American Academy of Jurisprudence, Box 20, Folder 16) (copy on file with author). ("[W]e are charged so generally with indifference where as a matter of fact we are simply overwhelmed with work.").

${ }^{194} \mathrm{Id}$.

${ }^{195}$ Letter from Wm. H. Taft, Alton B. Parker, Elihu Root, Henry Wade Rogers, James D. Andrews (Feb. 11, 1914) (copy on file with author). The letter asked that communications be addressed to Andrews. On the 17th, Andrews suggested to Pound that he should arrange with Taft and Root to ensure that at least one of the three would speak at the program. Letter from James D. Andrews to Roscoe Pound (Feb. 17, 1914) (copy on file with author).
} 
meeting. ${ }^{196}$ Asked about the purpose of the organization, Parker said he could provide no clearer explanation than "to promote the science of jurisprudence and the improvement of the law and its administration," but that a more comprehensive statement would be available soon. Andrews, who chaired the meeting, mostly echoed Parker's comments, emphasizing the needs for system and greater uniformity, concluding his remarks by saying: "Any one [sic] who approaches the task with the idea that the adoption of any particular plan or system is the uttermost goal loses sight of the paramount object . . . . the systematic restatement of our laws." 197

Wire service accounts appeared in newspapers elsewhere in the country. ${ }^{198}$ The Augusta Chronicle quoted Andrews regarding three "concepts" of the Academy's work: encouragement of systematic research, recognition of a system of legal education, and systematic restatement of the law. He commented also on the need to preserve legal scholarship. Parker was quoted as saying that "agitation among leading law schools" had led to creation of the academy. ${ }^{199}$

Taft was elected President of the Academy, although he participated only briefly in the meeting. According to the Times, he attended for "a few minutes in the afternoon, but had to attend the Police Lieutenants' dinner" in the evening. ${ }^{200}$ Other elected officers were Parker as First VicePresident, Frederick Lehmann as Second Vice-President, Andrews as Secretary, and Andrews's friend Waldo G. Morse as Treasurer. The published version of the constitution and bylaws listed fifty-six charter members. ${ }^{201}$

In late February, Wigmore received a brief report on the meeting from New Haven attorney Edward A. Harriman, who found it to be "really absurd that there should be an American Academy of Jurisprudence and that [Wigmore] should not be part of it."202 Wigmore responded that he was "deeply complimented by your suggestion as to the, so called, Academy taking me in. If I could be sure that J.D. Andrews had not taken in the rest of you, I should not hesitate about being taken in by yourselves." After noting the "subservience" shown to Andrews by electing him to the board of directors, Wigmore had two questions for Harriman, wondering first how many members

\footnotetext{
${ }^{196}$ Lawyers Organize to Simplify Law, N.Y. TIMES, Feb. 22, 1914, at 3. Nine years later the Times would use a nearly identical headline to announce the organization of the American Law Institute. See Jurists Organize to Simplify Law, N.Y. TIMES, Feb. 24, 1923, at 10.

${ }^{197}$ Lawyers Organize, supra note 196.

198 See, e.g., Leaders of Bar to Improve Service, THE STATE (Columbia, S.C.), Feb. 22, 1914, at [1]; Mr Taft Heads the American Academy of Jurisprudence, Augusta CHRON. (Augusta, Ga.), Feb.22, 1914, at 4; American Academy of Jurisprudence, ATlAnta Const., Feb. 22, 1914, at A2; Would Codify American Law: Bar Leaders Start Academy of Jurisprudence, LOS ANGELES TIMES, Feb. 22, 1914, at I4; Bar Leaders Organize, WASHINGTON POST, Feb. 22, 1914, at 1. American Academy of Jurisprudence Formed, BosTON HERALD, Feb.22, 1914, at 4.

The meeting was also reported with little additional information in several law magazines. See, e.g., The American Academy of Jurisprudence, 20 MICH. Alumnus 295 (1914); Codification, 22 LAW STUD. HELPER 4 (1914); American Academy of Jurisprudence, 18 LAW NOTES (Edward Thompson Co.) 2 (1914) (wondering if formation of the Academy were an "entering wedge" to complete codification); The American Academy of Jurisprudence, 26 GREEN BAG 200 (1914).

${ }^{199} \mathrm{Mr}$. Taft, supra note 198 at 4.

${ }^{200}$ Lawyers Organize, supra note 196 at 3.

201 AMERICAN ACADEMY OF JURISPRUDENCE CONSTITUTION AND BY-LAWS [7] ([1914]) (copy on file with author).

${ }^{202}$ Letter from Edward A. Harriman to John H. Wigmore (Feb. 24, 1914) (Wigmore Papers, Box 20, folder 16) (copy on file with author). Harriman was an occasional lecturer at Yale Law School and had collaborated with Wigmore on the sixteenth edition of Greenleaf on Evidence in 1899. See generally Edward Avery Harriman, 1 EVERETT G. HiLl, A MODERn HISTORY OF NEW HAVEN AND EASTERn NEW HAVEN COUNTY 111-12 (1918).
} 
attended the meeting in New York, then "By what express clauses in your By-Laws have you attempted to protect yourself against Sinbad Andrews?" 203

In a lengthy reply, Harriman told Wigmore that about a dozen Academy members attended the meeting, but took issue with Wigmore's comments about being "taken in" by Andrews, pointing out that he himself, along with Williston and Bates, had framed the Academy constitution. Williston had been "especially insistent" that no expenses be incurred or general schemes initiated without approval of the full membership. ${ }^{204}$ Harriman questioned the suggestion that the charter members were "subservient" to Andrews because they elected him to the Academy Council, emphasizing both the general quality of the membership and that the Harvard professors had joined only after Andrews had complied with their demands. Andrews's election was inevitable in light of his work organizing the academy. "I feel no more subservience to him in voting for his election to the council, than I would feel subservience to you if I had accepted your views and stayed out of the Academy."205

Henry Bates of the University of Michigan wrote in March to ask whether Wigmore had stricken his name from Wigmore's "list of possible friends" because he had attended the meeting, but expressed his hope that he, Williston, Harriman, Beale, and others would be able "not only to prevent an ignorant attempt to do the impossible but even to make this organization useful . ..."206 Wigmore replied that his main reason for not participating was to "keep the matter from becoming the personal organ of Mr. Andrews" was, and warned that "I am by no means satisfied that your victory in the first struggle means ultimate victory. I am afraid that known [sic] of you quite appreciate the deadly persistency of that man." 207 Bates wrote back agreeing with Wigmore that "Andrews cannot be managed and that his obstinate obsession is likely to prevent the achievement of the hopes of Williston, Pound, Harriman, and two or three others who were at the New York meeting." He remained hopeful that with the participation of those men and others with similar interests the organization could be the foundation for future systematic work, but "I confess I seriously doubt whether we can bring the present organization into line with the views of such men." 208

\footnotetext{
${ }^{203}$ Letter from John H. Wigmore to Edward A. Harriman (Mar. 3, 1914) (Wigmore Papers, Box 247, folder 1) (copy on file with author).

${ }^{204}$ Letter from Edward A. Harriman to John H. Wigmore (Mar. 7, 1914) at 1 (Wigmore Papers, Box 247, folder 1) (copy on file with author). Harriman noted that although "Williston seemed to take a strong interest in the corpus juris ... his interest is not of a character which will result in the hastening of that great work." Id.

${ }^{205} \mathrm{Id}$. at 2 . On April $10^{\text {th }}$, Wigmore wrote Harriman to ask for a list of Academy members in order to send each a prospectus for the Modern Legal Philosophy Series that he was working on for the AALS: "I would rather not apply personally to Mr. Andrews, or whoever is secretary." Letter from John H. Wigmore to Edward A. Harriman (Apr. 10, 1914) (Wigmore Papers, Box 247, folder 1) (copy on file with author).

${ }^{206}$ Letter from Henry M. Bates to John H. Wigmore (Mar. 20, 1914) (Wigmore Papers, Box 247, folder 1) (copy on file with author).

${ }^{207}$ Letter from John H. Wigmore to Henry M. Bates (March 26, 1914) (Wigmore Papers, Box 247, folder 1) (copy on file with author).

${ }^{208}$ Letter from Henry M. Bates to John H. Wigmore (Apr. 8, 1914) at 1 (Wigmore Papers, Box 247, folder 1) (copy on file with author). In other correspondence, Wigmore made occasional references to the "so-called" Academy. See, e.g., Letter from John H. Wigmore to Morris N. Cohen (March 13, 1914) (Wigmore Papers, Box 247, folder 1) (copy on file with author); Letter from John H. Wigmore to John Bassett Moore (April 22, 1914) (Wigmore Papers, Box 247, folder 1) (copy on file with author). In an undated handwritten note to Nathan McChesney he wrote: "I have declined to have anything to do [with the Academy], so long as J.D.A. has them in his clutches." Letter from John H. Wigmore to [Nathan] McChesney (n.d.) (Wigmore Papers, Box 247, folder 1) (copy on file with author).
} 


\section{Andrews and Taft}

In April, Andrews wrote to Taft, Pound, and others regarding their availability for a May meeting of the fifteen-member Academy Council "to consider plans and policy." 209 Taft wrote he could not attend a meeting in May. ${ }^{210}$ On May 29, Andrews asked Taft to set a June meeting of the Council to prepare for the regular Academy meeting in the fall. At the proposed meeting, Andrews would "submit comprehensive and detail [sic] plans which will serve as a basis for reflection on the part of the members as to the basic principles and main divisions of classification." Once a classification plan was adopted, financing should not be difficult since U.S. lawyers "have, in the last thirty years, paid over Fifteen million dollars for the three editions of books of this general scope." He also proposed that the Council authorize him to travel to Europe in order to consult leading jurists on the plans, and included a separate outline "intended to show the internal unity and common dependence of all the modern European systems upon the Civil Law." 211

On June 3 Taft wrote that it was unwise either to meet "at this time when everyone is busy," or to provide Andrews "a roving commission of the Council to Europe, even at your own expense for the purposes indicated in your letter" 212 then continued:

I regret to put the matter as bluntly as this, but I think most of those who went into the Council went into it with the distinct understanding that this was met for the purpose of promoting the publication of the law on the theory which you have heretofore advanced, and that we were not to be committed to the project of promoting a Corpus Juris. ${ }^{213}$

In response Andrews suggested that Taft had misunderstood his earlier letter, which he thought had "expressly stated" that the Academy was committed to no specific plan for classification, "nor the promotion of any publication which I have proposed." He asked to meet with Taft to discuss the objects of the Academy, which he believed offered Taft "the greatest opportunity of anything which lies before you." To succeed the Academy needed Taft's agreement: "[A]s you realize I cannot move forward excepting with your sanction." 214 In September, Andrews argued that at no point had he advocated for the Academy to endorse his ideas on classification or for the publication of a book, ${ }^{215}$ and expressed his own belief that the members of the Academy were committed to promoting a Corpus Juris to the end of "a more simple, certain, and harmonious system of law." 216

\footnotetext{
${ }^{209}$ See, e.g., Letter from James D. Andrews to Roscoe Pound (Apr. 15, 1914) (copy on file with author); Letter from James D. Andrews to William H. Taft (April 14, 1914) (Taft Papers Series 3 Reel 139) (Copy on file with author). ${ }^{210}$ Letter from William H. Taft to James D. Andrews (April 20, 1914) (Taft Papers Series 8 Reel 524) (Copy on file with author). Upon receipt of Andrews's April 14 letter, Taft's secretary Wendell Mischler had written Andrews to alert him that Taft would not be available. Letter from Secretary to James D. Andrews (April 16, 1914) (Taft Papers Series 8 Reel 524) (Copy on file with author).

${ }^{211}$ Letter from James D. Andrews to William H. Taft (May 29, 1914) (with enclosure) (Taft Papers Series 3 Reel 140) (Copy on file with author).

${ }^{212}$ Letter from William H. Taft to James D. Andrews (June 3, 1914) (Taft Papers Series 8 Reel 525) (Copy on file with author).

${ }^{213} I d$.

${ }^{214}$ Letter from James D. Andrews to William H. Taft (July 6, 1914) (Taft Papers Series 3 Reel 141) (Copy on file with author).

${ }^{215}$ Letter from James D. Andrews to William H. Taft (Sept. 14, 1914) at 1 (Taft Papers Series 3 Reel 143) (Copy on file with author).

${ }^{216} \mathrm{Id}$. at 4 .
} 
On October 2, Taft advised Andrews that the best role for the Academy would be to support other established movements, such as the Commission for Uniform State Laws, or to promote improvements in judicial procedure. "In the matter of codifying the law, or producing a Corpus

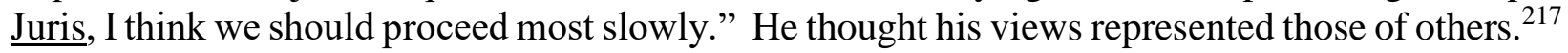

On October 7 Andrews wrote twice to Taft. His first letter responded to Taft's of October 2, and agreed with the suggestion to move slowly and make no decisions without "full hearing and deliberate consideration." But Andrews also reminded Taft of the many years he had devoted to "examining the data and studying the processes of classical and modern Jurists and reformers," which had led him to believe that, while his own conclusions might not be right and his plans impractical, they were worthy of consideration. He concluded: "[I]f I may be permitted to speak as bluntly as you spoke to me, I think we do less than our duty to the profession, to the public and to ourselves if we longer delay the inauguration of our practical activities." 218

Andrews's other letter proposed a possible alliance between the Academy and the American Law Book Company, ${ }^{219}$ which was about to issue the first volumes of a new encyclopedia proclaimed to be "a full, complete, and at the same time, concise statement of all the law as declared in all the decisions" under the title: Corpus Juris. ${ }^{220}$ Despite his earlier criticisms of legal encyclopedias, Andrews found the first volume of Corpus Juris to be "exhaustive and comprehensive," employing methods that provided "an excellent starting point" for the Academy's activities, as well as opportunities for collaboration. The Academy's research departments could "take up the confused spots in the law where [the encyclopedia] and decisions will have left them and ... work out a rational solution." 221 Because of its potential benefits, the Academy should meet to discuss the idea during the upcoming annual meeting of the ABA. ${ }^{222}$

On October 17 Andrews wrote to members of the Academy proposing an informal meeting the following week, enclosing a copy of his October 7 letter to Taft regarding the American Law Book Company. ${ }^{223}$ Although Taft seems not to have replied to that letter, he quickly replied to Andrews's October 17 letter to the larger group. On October 19, he informed Andrews that neither he nor "any of my colleagues" could attend a meeting on the proposed dates, and that "Speaking for myself I am decidedly opposed to the project set forth in your letter; and whether it is sound or not it is certainly far too serious and far-reaching a matter to be taken up without ample notice to

\footnotetext{
${ }^{217}$ Letter from William H. Taft to James D. Andrews (Oct. 2, 1914) (Taft Papers Series 8 Reel 525) (Copy on file with author).

${ }^{218}$ Letter from James D. Andrews to William H. Taft (Oct. 7, 1914) (Taft Papers Series 3 Reel 143) (Copy on file with author) [hereinafter Andrews to Taft (Oct. 7, 1914) I].

${ }^{219}$ Letter from James D. Andrews to William H. Taft (Oct. 7, 1914) (Taft Papers Series 3 Reel 143) (Copy on file with author) [hereinafter Andrews to Taft (Oct. 7, 1914) II].

${ }^{220}$ William Mack \& William Benjamin Hale, Preface, 1 CORPUS JURIS v, vi (1914). Corpus Juris (1914-1937) succeeded the same publisher's Cyclopedia of Law and Procedure (1901-1912). Corpus Juris Secundum (1936date) was published by West Publishing Co. (now Thomson Reuters), but until 1966 also bore the American Law Book Co. imprint.

${ }^{221}$ Andrews to Taft (Oct. 7, 1914) II, supra note 219 at 1-2.

222 Id. at 3.

${ }^{223}$ Letter from James D. Andrews to Roscoe Pound (Oct. 17, 1914) (copy on file with author).
} 
members of the academy." He asked that consideration of the matter be postponed to a later meeting. 224

In November, an apparently cowed Andrews again wrote Taft regarding the need for a Council meeting, suggesting as well that the two men meet at Taft's convenience "in order to arrive at a better common understanding of the methods of carrying out the objects of the Academy." He again expressed confidence that "[t]here will be no difficulty in providing ample means for accomplishment of any work [,] however large, the control, oversight and direction of which the Academy will undertake." 225 Enclosed with the letter were six pages of possible projects, buttressed with quotations from legal luminaries, which Andrews hoped to send to members for comment. The paper closed by stating that the suggestions were "not made with the purpose of arguing for any particular method or plan. ..."226 Taft's short reply acknowledged the materials, but said he thought that the meeting could not be held before Christmas. ${ }^{227}$ Taft's papers include no further correspondence regarding the Academy for the next eighteen months. ${ }^{228}$ In July 1916, Andrews sent Taft a five-page letter reporting his sense that conditions were now favorable to "the establishment of Jurisprudence as a practical and efficient factor in the development of law." According to Andrews, law professors had come to appreciate that scientific elements of legal education were being ignored in legal education, and " $[\mathrm{t}]$ he leaders of thought are beginning to see that Scientific Classification is the practical means of imparting the qualities of simplicity and certainty." 229

Andrews reminded Taft of his 1914 proposal to interview continental jurists to verify his own long-held positions on classification or to convince "[him]self of error and discover if possible the true theory and methods." 230 Now, he believed that Josef Redlich's report to the Carnegie Foundation on the common law and the case method ${ }^{231}$ not only supported, but elaborated the

\footnotetext{
${ }^{224}$ Letter from William H. Taft to James D. Andrews (Oct. 19, 1914) (Taft Papers Series 3 Reel 144) (Copy on file with author).

${ }^{225}$ Letter from James D. Andrews to William H. Taft (Nov. 11, 1914) (with enclosure) (Taft Papers Series 3 Reel 144) (Copy on file with author).

${ }^{226}$ Suggestions concerning Possible Activities of the American Academy of Jurisprudence 6 (enclosed with id.).

${ }^{227}$ Letter from William H. Taft to Mr. James D. Andrews (Nov. 14, 1914) (Taft Papers Series 8 Reel 527) (Copy on file with author).

${ }^{228}$ In June 1915, having noticed Taft's upcoming address on judicial settlement of international disputes, Andrews wrote to be sure Taft knew that James Wilson had thought about this, as had Andrews himself. For good measure he enclosed advertisements endorsing his edition of Wilson's works. Letter from James D. Andrews to William. H. Taft (June 21, 1915) (Taft Papers Series 3 Reel 153) (Copy on file with author).

${ }^{229}$ Letter from James D. Andrews to William. H. Taft 1 (July 27, 1916) (Taft Papers Series 3 Reel 168) (Copy on file with author). The letter included several pages torn from the 1911 pamphlet calling for establishment of the Academy. See AMERICAN ACADEMY OF JURISPRUDENCE: PlAN FOR ESTABLISHING It, supra note 163.

${ }^{230}$ Letter from Andrews to Taft (July 27, 1916), supra note 229 at 2.

${ }^{231}$ JOSEF REDLICH, THE COMMON LAW AND THE CASE METHOD IN AMERICAN UNIVERSITY LAW SCHOOLS: A REPORT TO THE CARNEGIE FOUNDATION FOR THE ADVANCEMENT OF TEACHING (1914). Although he did not discuss Redlich's report in detail, Andrews seemed to focus on its emphasis on offering not only practical courses employing the case method, but also an introductory course on the legal system and later courses on common law jurisprudence and the civil law. Redlich's comments on these "weaknesses" of exclusive reliance on the case method, $i d$. at 41-47, were excerpted in the preface to the report. See Henry S. Pritchett, Preface, id. at iii, viii-x. See also James Dewitt Andrews, Jurisprudence: Development and Practical Vocation, 25 YALE L.J. 306, $320-22$ (1916) (discussing Redlich's report).
} 
positions Andrews had expressed earlier. ${ }^{232}$ He believed that at its last meeting the Association of American Law Schools had sympathetically taken up Redlich's report. ${ }^{233}$

To Andrews, these events provided a "great opportunity" for the Academy: "The principle obstacles to harmonious action are removed and the field of debate cleared of fundamental questions . . . . The leaders of the profession see that reform must proceed along lines of comprehensive systematic restatement. It is made apparent to all that classification is the essential process." $234 \mathrm{He}$ closed by urging Taft to seize the opportunity and asked to meet prior to the upcoming ABA meeting. Taft replied that he would be "very glad" to see Andrews in August in Chicago. ${ }^{235}$ The proceedings of the ABA meeting suggest that both men attended, but Taft's papers do not indicate whether they met.

\section{Root's 1916 ABA Speech}

In his 1916 ABA presidential address, Elihu Root warned that "[t]he vast and continually growing mass of reported decisions which afford authorities on almost every side of every question admonish us that by the mere following of precedent we should soon have no system of law."236 For Root, the solution was "the simple and natural course of avoiding confusion by classification, system, the understanding and application of generally recognized and accepted legal principles." Like Terry, Root saw classification as a way to help the bar "see through the precedents and the incidents to the controlling principles." ${ }^{237} \mathrm{He}$ dismissed the possibilities for accomplishing this goal by writing textbooks, preaching reform, or imposing a civil law system on the common law. Rather, he cited the "very able and public spirited lawyers," who "have been for some years urging the organization of a definite and specific movement for the restatement of our law; for a new American Corpus Juris Civilis. They are quite right. It ought to be done."238

${ }^{232}$ Letter from Andrews to Taft (July 27, 1916), supra note 229 at 3, citing Report of Committee on Legal Education, 26 Proc. Ill. St. B. Assoc. 201 (1902); Report of Committee on Legal Education, 27 PROC. ILL. ST. B. Assoc. 163 (1903). Punctuated by lengthy quotations from well-known lawyers and jurists, the 1902 report elaborated on points in Andrews's 1895 American Lawyer discussion of legal education, Andrews, Legal Education, supra note 73, arguing that jurisprudence was not given its proper place in the curriculum, and that the educational process lacked a uniform system, something that could be solved if there were "universal recognition of a common corpus juris." Report of Committee on Legal Education (1902), supra at 213.

${ }^{233}$ Letter to Taft (July 27, 1916), supra note 229 at 2. The comment apparently refers to discussions of Redlich's report at the 1915 AALS meeting, which featured papers by Columbia dean Harlan Stone and Stanford Executive Head, Frederic Woodward. See Papers and Discussion Concerning the Redlich Report, 15 A.A.L.S. PROC. 77 (1915). Both papers questioned the need for an introductory course in law, particularly if offered using lectures. There is no indication of any action taken by the AALS beyond sponsoring the discussion.

${ }^{234} I d$. at 4.

${ }^{235}$ Letter from William H. Taft to James D. Andrews (July 31, 1916) (Taft Papers Series 8 Reel 540) (Copy on file with author).

${ }^{236}$ Elihu Root, Address of the President, 39 ANN. REP. A.B.A. 355, 364 (1916)

${ }^{237}$ Id. at 365 .

${ }^{238}$ Id. It was not surprising that in his ABA speech he looked to practitioners, not law teachers, for progress on classification. Jerold Auerbach notes that at a January 1916 dinner honoring his election to the ABA presidency, Root had found law school faculties to be populated by "half-baked and conceited theorists" who believe that "they know better what law ought to be than the people of England and America, working out their laws through centuries of life.” Elihu Root, Address, 39 N.Y. ST. B. Assoc. REP. 473, 479 (1916), quoted in Jerold S. Auerbach, Enmity and Amity: Law Teachers and Practitioners, 1900-1922 in 5 PERSPECTIVES IN AMERICAN HISTORY: LAW IN AMERICAN HISTORY 551, 572 (Donald Fleming and Bernard Bailyn, eds. 1971). On Root's interest in law reform during his later years, see generally II PHILIP C. JESSUP, ELIHU ROOT 467-71 1938). 
His reference to the American Corpus Juris project was outdated, but Root's comments gave new encouragement to Andrews and his colleagues. Shortly before the ABA meeting, Andrews had sent Pound a short typewritten note, saying only "I want to have a tlak [sic] with you. Are you there, if not, where are you? 'If you don't get this write." ${ }^{239}$ In mid-September, shortly after Root's address, Andrews told Pound that if Pound could "squeeze out a couple hours early next week," he would come to Boston to discuss an important matter for which "expedition is so desirable." 240 Pound replied that with the school year about to begin it would be impossible to meet, but he would glad to see Andrews after things settled down. ${ }^{241}$

In December Andrews sent Taft a six-page letter similar to that he wrote in July, proclaiming again that " $[\mathrm{t}]$ he time has come for The American Academy of Jurisprudence to move forward for the attainment of its objects." ${ }^{242}$ But this time he suggested that Taft had "not taken much interest in these," and asked whether Taft was "willing to go earnestly forward in those light but dignified duties which devolve upon the president of the organization." Andrews offered to demonstrate personally what could be accomplished, but also made his case in the letter, which discussed the Academy's goals in legal education, ${ }^{243}$ then traced the history of his efforts to develop a systematic restatement of the law, emphasizing Root's ABA comments. He had been skeptical about Root's mention of the Corpus Juris Project, until Root "expressly stated to me in the presence of others that he had in his address given the project (saying 'your project') a boost."244

Andrews then described a recent five hour meeting with Pound for "the careful and painstaking examination of these plans and details," which resulted in Pound's general approval of Andrews's plans although the details of classification were left for future discussion. ${ }^{245}$ "Mr. Pound went so far as to use the expressions 'wonderful' and 'brilliant,' and expressed his belief that the carrying out of these plans would present a restatement of our law far superior to anything which has yet appeared." According to Andrews, Pound pledged his cooperation and support, and knew nine

\footnotetext{
${ }^{239}$ Letter from James D. Andrews to Roscoe Pound (Aug. 1, 1916) (quotation marks in original) (Copy on file with author). A return note from Harvard informed Andrews that Pound was traveling but would attend the ABA meeting at the end of the month, although it seems that they did not meet there. See Letter from [unknown] to James D.

Andrews (Aug. 3, 1916) (Copy on file with author).

${ }^{240}$ Letter from James D. Andrews to Professor Roscoe Pound (Sept. 15, 1916) (Copy on file with author). Andrews enclosed a passage from Wilson's writings, asking: "Does it squint along your line of thought?" Id.

${ }^{241}$ Letter from Roscoe Pound to James D. Andrews (Sept. 16, 1916) (Copy on file with author).

Pound's papers also include an October 2 handwritten note from Eugene Prussing, describing his attempts with Andrews to respond to "Mr. Root's question in his Chicago address concerning the whereabouts of a group of men, and a leader, to formulate an American Corpus Juris Civilis," which the note suggested he had discussed with Pound the previous week. Prussing reported that he would soon seek agreement from Root and Simeon Baldwin to work on the project with Andrews, Pound and Hampton Carson, Root to serve as chair. (Taft is not mentioned.) See Letter from Eugene E. Prussing to Roscoe Pound (Oct. 2, 1916) (Copy on file with author). A response from Pound dated October 11, suggests that Pound did not remember receiving Prussing's October 2 note. Letter from Roscoe Pound to Eugene E. Prussing (Oct. 11, 1916) ("I am quite at a loss to know to what you refer.") (Copy on file with author). On the 12th Prussing reported that he still hoped to see Carson, Baldwin, and Root. Letter from Eugene E. Prussing to Mr. Roscoe Pound (Oct. 12, 1916) (Copy on file with author).

${ }^{242}$ Letter from James D. Andrews to William. H. Taft 1 (Dec. 6, 1916) (Taft Papers Series 3 Reel 172) (Copy on file with author).

${ }^{243} I d$. at 2-3 (again citing his 1902-1903 reports to the Illinois bar association, the sentiments of which had been "repeated by Dr. Redlich and again emphasized by Mr. Root.").

${ }^{244} I d$. at 4.

${ }^{245}$ Id.
} 
others who would participate. ${ }^{246}$ Andrews closed his letter with an idea for promoting "scientific legislation" through cooperation among state legislative reference bureaus, and an offer to meet with Taft and others in New Haven to review materials that Andrews had prepared to provide "real evidence" for the plans. ${ }^{247}$

Two days later in response to a note from Taft's secretary Wendell Mischler Andrews wrote that the burdens on Taft (and Mischler) of continuing with the project would be slight because the Academy would provide secretarial support. ${ }^{248}$ Nonetheless, on December 11 Taft told Andrews: "I think that you and I do not agree on this general subject, and as you seem to be the moving spirit in the American Academy of Jurisprudence, you had better let me resign." 249 Andrews replied that he was sure Taft had not meant to suggest that a disagreement had developed between them. He had not changed his own views and had tried repeatedly to meet with Taft to discuss them. Because they had not met, "[i]t would be unfair and prejudicial for you to base your resignation on a misapprehension .... I trust you will come and see me or send for me to see you before taking any action." 250 In January Andrews again requested a meeting, doubting that Taft would want to resign the presidency "after an hour's examination of the plans, material and resources of financial and professional support." He understood the demands on Taft's time, but believed that the time spent on the project would benefit his efforts in other areas. ${ }^{251}$ Mischler replied the following day to say that Taft was away, but he would bring the letter to his attention when he returned. ${ }^{252}$ Taft's papers include no further correspondence with Andrews until April 1922.

In a May 1916 letter, after noting his brief meeting with Prussing the previous fall and longer talk with Andrews, Pound told Lucien Alexander that he knew little regarding the current status of the Corpus Juris project. He didn't know what Andrews had done since: "I doubt he has done anything. The times are not propitious at present for such undertaking.",253

\section{The AALS Juristic Center Discussions}

Speaking before the ABA in 1915, Felix Frankfurter called upon the legal profession to demand that law schools take on "the work not merely of training practitioners but of helping to develop

\footnotetext{
${ }^{246}$ Id. at 5. The following May, Pound mentioned his fall meeting with Andrews in a letter to Lucien Alexander, suggesting that he found Andrews's plan to be in many ways worthwhile, but that neither he nor his Harvard colleagues could offer much assistance because of other work. Letter from Roscoe Pound to Lucien Hugh Alexander (May 16, 1917) (Copy on file with author). On Pound's efforts to discuss the project with Beale and Williston, see Letter from Roscoe Pound to James D. Andrews (Nov. 15, 1916); Letter from Roscoe Pound to James D. Andrews (Nov. 18, 1916) (Copies on file with author).

${ }^{247}$ Letter from Andrews to Taft (Dec. 6, 1916), supra note 242 at 6.

${ }^{248}$ Letter from James D. Andrews to Wendell W. Mischler (Dec. 8, 1916) (Taft Papers Series 3 Reel 172) (Copy on file with author). Mischler's earlier letter to Andrews is not in the Taft Papers.

${ }^{249}$ Letter from William H. Taft to Mr. James D. Andrews (Dec. 11, 1916) (Taft Papers Series 8 Reel 543) (Copy on file with author).

${ }^{250}$ Letter from James D. Andrews to William. H. Taft 1 (Dec. 14, 1916) (Taft Papers Series 3 Reel 172) (Copy on file with author).

${ }^{251}$ Letter from James D. Andrews to William. H. Taft 1 (Jan. 9, 1917) (with enclosures) (Taft Papers Series 3 Reel 174) (Copy on file with author).

${ }^{252}$ Letter from Secretary to Mr. James D. Andrews (Jan.10, 1916) (Taft Papers Series 3 Reel 174.) (Copy on file with author).

${ }^{253}$ Letter from Pound to Alexander (May 16, 1917), supra note 246.
} 
the law, ..."254 Specifically he saw a solution for the "tendency to particularism" in American law if the law schools were devoted to "systematic treatment of the law [and] production of treatises of commanding authority ... to further unity of decisions and thereby uniformity of law in the various jurisdictions." 255

Later the same year, Harry Richards of the University of Wisconsin used his AALS presidential address to urge law teachers to be leaders in the movement for historical and scientific analysis, and simplification of the law. ${ }^{256}$ Richards referenced Wesley Hohfeld's suggestion at the 1914 AALS meeting that there was presently "an unusually great opportunity to persuade men that the kind of institution . . . most deserving to be fostered in behalf of the public interests is a great school of jurisprudence and law ...."257 When Richards finished, George Boke of the University of California, Joseph Beale, and William Draper Lewis urged the appointment of a committee to immediately consider preliminary steps to follow up on his suggestions, particularly for establishment of a national center for study of law and jurisprudence. ${ }^{258}$ The next day that committee, consisting of Boke, Beale, and Lewis, presented a resolution calling for a report the following year on issues involved in establishing a juristic center. ${ }^{259}$

In 1916, the Committee on a Juristic Center, chaired by Richards, recommended against establishment of an independent juristic center, proposing instead a new standing committee to consider how best to promote interest in the study of jurisprudence. ${ }^{260}$ Boke filed a minority report supporting creation of a center and calling for a conference to discuss the question. ${ }^{261}$ After brief discussion, both reports were tabled, where they remained until 1920, when President Eugene Gilmore tasked a special committee to organize law teachers into "an effective organization to deal with the large problem of legal education and law reform." 262

In 1921, the special committee's report on improvements to the law was distributed, but withdrawn before the annual meeting because of disagreements among the committee members. ${ }^{263}$

\footnotetext{
${ }^{254}$ Felix Frankfurter, The Law and the Law Schools, 38 ANN. REP. A.B.A. 365, 372 (1915). In 1971 Jerold Auerbach suggested that Frankfurter's talk marked the close of the formative decades for American law teachers. Auerbach, supra note 258 at 555.

${ }^{255}$ Frankfurter, supra note 254 at 372.

${ }^{256}$ Harry S. Richards, Address of the President: Progress in Legal Education, 15 A.A.L.S. Proc. 60 (1915)

${ }^{257}$ Id. at 75 ("We may even hope in time that the idea back of Professor Hohfeld's paper may be realized by the establishment under the auspices of this Association of a center for such studies in Washington."), citing Wesley Newcomb Hohfeld, Vital School of Jurisprudence and Law: Have American Universities Awakened to the Enlarged Opportunities and Responsibilities of the Present Day?, 14 A.A.L.S. PROC. 76 (1914).

${ }^{258}$ Minutes of the Fifteenth Annual Meeting, 15 A.A.L.S. PROC. 23, 27-29 (1915).

${ }^{259} \mathrm{Id}$. at 30-31. The idea of a school dedicated to the study of jurisprudence was also raised at the 1916 ABA meeting. See Frank J. Goodnow, Private Rights and Administrative Discretion, 39 ANN. REP. A.B.A. 408 , 423 (1916).

${ }^{260}$ See Report of the Committee on a Juristic Center, 16 A.A.L.S. PROC. 180, 181-82 (1916). Other members of the committee were Beale, Boke, and Harlan Stone.

${ }^{261}$ See Minority Report of Juristic Center Committee, 16 A.A.L.S. Proc. 183, 184 (1916). See generally Hull, Restatement and Reform, supra note 19 at 58-65

${ }^{262}$ Minutes of the Eighteenth Annual Meeting, 18 A.A.L.S. Proc. 70,76 (1920). See also Eugene A. Gilmore, Some Criticisms of Legal Education, 18 A.A.L.S. Proc. 140, 154 (1920). Because of the war, the AALS did not meet in 1917 and 1918.

${ }^{263}$ Report of the Special Committee on Round Table Conferences and a Juristic Center, A.A.L.S NINETEENTH ANNUAL MEETING PROGRAMS AND REPORTS OF COMMITTEES 13 (1921) (copy on file with author, thanks to the Harvard Law Library). There are few copies of the original report available.
} 
Committee chair Beale offered a verbal report calling for appointment of a committee empowered to invite representatives from all branches of the profession jointly to create a permanent organization to improve the law. ${ }^{264}$ In 1922 the Juristic Center committee reported on the creation of a Committee on the Establishment of a Permanent Organization for the Improvement of the Law, which would lead the following year to the establishment of the American Law Institute and restatement project. ${ }^{265}$ The following year the AALS committee reported that it had been merged into the ALI committee ${ }^{266}$; in 1924 it became part of a new AALS Committee on Co-operation with the Bench and Bar. ${ }^{267}$

\section{Second ABA Special Committee on Classification}

In 1917 ABA president Walter George Smith appointed a new Special Committee to Consider Classification and Restatement of the Law. Andrews was not named to the committee, but four of the five members, including chair Hampton Carson, were charter members of the Academy of Jurisprudence. ${ }^{268}$ Andrews joined the committee in 1918; Carson continued as chair. In 1919 the special committee offered a short report, citing Root's 1916 remarks and the purpose clause of the ABA constitution ${ }^{269}$ to recommend that it be continued and enlarged, and charged to develop plans for a conference of scholars and jurists to consider classification and restatement. ${ }^{270}$ In both the written report and his remarks on the floor ${ }^{271}$ Carson carefully distinguished the two matters: "The Committee is unanimous on the desirability of a scientific classification of the law, and urges the advisability of a systematic consideration of the subject by this Association at as early a time as

\footnotetext{
${ }^{264}$ Minutes of the Nineteenth Annual Meeting, 19 A.A.L.S. Proc. 48, 115-16 (1921) (Report of the Special Committee on Round Table Conferences and a Juristic Center). As passed, the Resolution read:

That a Committee be appointed with power to invite the appointment of similar committees representing the courts, the bar associations, the professional and other scientific and learned bodies engaged in the study of the substantive and adjective law, and its administration for the purpose of jointly creating a permanent organization for improvement of the law; with power to name a time and place for the meeting of a conference of these Committees.
}

Id. at 123. The original report had called both for a comprehensive restatement of the law, as well as for creation of an American Law Institute and an Academy of Law to accomplish the work. Report of the Special Committee on Round Table Conferences and a Juristic Center, supra note 263 at 14. See generally Hull, Restatement and Reform, supra note 19 at 67-74.

${ }^{265}$ Report of the Committee on the Juristic Center, 19 A.A.L.S. Proc. 37, 38 (1922). See also Minutes of the Nineteenth Annual Meeting, 20 A.A.L.S. PROC. 125 (1922) (comments of Harlan Stone).

${ }^{266}$ Report of the Committee on the Juristic Center, supra note 265 at 27.

267 See Minutes of the Twenty-Third Annual Meeting, 23 A.A.L.S. PrOC. 5, 104 (1925). The resolution creating the new committee was prompted by remarks made by Lewis in his presidential address. See William Draper Lewis, The President's Address, 23 A.A.L.S. Proc. 65, 73-74 (1925).

${ }^{268}$ See Special Committees: 1917-1918, 40 ANN. REP. A.B.A. 192, 194 (1917). In addition to Carson, Frederick Lehman, Adolph Rodenbeck, and Samuel Williston were charter members of the Academy; Edgar Bancroft was not. Because of the war, the committee offered no report in 1918. See Transactions of the Forty-First Annual Meeting of the American Bar Association, 41 ANN. REP. A.B.A. 19, 90 (1918).

${ }^{269}$ See Constitution, supra note 19 at 30 (stating the purpose of the Association as "to advance the science of jurisprudence, promote the administration of justice and uniformity of legislation throughout the Union ....").

${ }^{270}$ Report of the Committee on Classification and Restatement of the Law, 42 ANN. REP. A.B.A. 259, 261 (1919).

LaPiana comments that when the war ended, "[t]he one type of reform to emerge with vigor was classification."

LaPiana, supra note 13 at 1118.

${ }^{271}$ Transactions of the Forty-Second Annual Meeting of the American Bar Association, 42 ANN. REP. A.B.A. 19,42 (1919). 
practicable...." Any effort toward restatement, however, would be "premature" and the Committee "refrains at this time from any expression of views in the matter of the restatement of the law." 272

Elected ABA president in 1919, Carson enlarged the special committee and named Adolph Rodenbeck as chair, ${ }^{273}$ but by April 1920, Rodenbeck had resigned the position and Andrews took his place. Andrews proposed a meeting of the committee in May, ${ }^{274}$ but changed the date to June to make it possible for Rodenbeck to attend. ${ }^{275}$ Andrews's correspondence with Pound suggests that the June meeting came off, but apparently few members were present. ${ }^{276}$

The Committee's 1920 report related the history of classification in American law, noting the earlier ABA committee, the formation of the American Academy of Jurisprudence in 1914, and the establishment of the current committee in $1917 .{ }^{277}$ In a shift of position, the 1920 Committee

${ }^{272}$ Report of the Committee on Classification and Restatement of the Law (1919), supra note 270 at 259.

${ }^{273}$ In addition to Rodenbeck the committee roster included Andrews, Lehman, Williston, David Amram, Bancroft, Pound, Harlan Stone, and David Trabue. See list at Special Committees: 1919-1920, 42 ANN. REP. A.B.A. 146, 147 (1919). Upon being notified of his appointment, Stone wrote Pound regarding his hesitancy to accept, presuming that Pound felt the same. Stone believed that the country was not ready for a general restatement. Letter from Harlan Stone to Roscoe Pound (Nov. 20, 1919) (copy available from author). Pound replied that: "I do not believe in the project at all. On the other hand, I am afraid that the Committee may get into the hands of a lot of enthusiasts who will put across a half-baked project which will do infinite harm." Letter from Roscoe Pound to Harlan F. Stone, (November 24, 1919) (copy available from author).

Rodenbeck's January 1919 address on classification and restatement to the New York State Bar Association had prompted the appointment of a committee to look at the matter. See Adolph J. Rodenbeck, The Classification and Restatement of the Law, 42 N.Y. STATE BAR ASSOC. 168, 196 (1919). For discussion of the committee's activities see supra, note 171. In 1987, LaPiana wrote: "[In New York,] the chairman of the Board of Statutory Consolidation, Adolph J. Rodenbeck, expected great things from a classification of the law into a gigantic outline whose headings would be formulated according to the principles of logic enunciated by Archbishop Richard Whately, nineteenthcentury English cleric and author of a widely-read treatise first published in 1823." LaPiana, supra note 13 at $1094-$ 95.

In 1925, Rodenbeck published his own book-length attempt at a classification system, The Anatomy of the Law, which was met with generally negative reviews. See Burke Shartel, Book Review, 24 MICH. L. REv. 523, 525 (1926) ("the learned author's classification is nice rather than convenient"); Isaac Husik, Book Review, 74 U. PA. L. REV. 418, 418 (1925-1926) (“The author 'cuts up' the law, he does little more.”); Karl N. Llewelyn, Book Review, 35 YALE L.J. 390, 390 (1926) ("To the reviewer the attempt seems a failure, when viewed as a whole. So, however, does every other attempt which he has thus far run across.") As late as 1954, in his 90s, Rodenbeck remained interested in restatements of state law. See Restatement of Decisions Sought, 22 HENNEPIN LAW. 138 1953-1954 (citing a paper read before the Rochester Bar Association).

${ }^{274}$ Letter from James D. Andrews to Professor Roscoe Pound (April 16, 1920) (Copy on file with author). In his letter, Andrews noted the New York bar committee's efforts to enlist the support of other state bar associations, "indicating a cordial willingness to cooperate in this movement." Id.

${ }^{275}$ Letter from James D. Andrews to Members of Said Committee (April 29, 1920) (Copy on file with author). In a hand-written postscript to Pound, Andrews urged Pound to attend and noted that "This thing is in good shape and we can put it through if we pull together." He enclosed what he called "some pretty good stuff": a typewritten paper on "How Prof. Sheldon Amos Supports Our Whole Scheme," and printed excerpts of comments by others.

${ }^{276}$ Pound did not attend. Letter from Roscoe Pound to James D. Andrews (June 7, 1920) (Copy on file with author). Andrews sent Pound a hand-written note on June 5th alerting him that Samuel Williston had returned to Cambridge with a copy of the draft committee report for Pound's review. Letter from James D. Andrews to Roscoe Pound (June $5,1920)$ (Copy on file with author). In his June $7^{\text {th }}$ letter, Pound responded that he would sign whatever Andrews, Rodenbeck and Williston agreed on.

${ }^{277}$ Report of the Special Committee on Classification and Restatement of the Law, 6 A.B.A. J. 420, 420-421 (1920). The report quotes at length from an apparently unpublished report by Yale professor Edward M. Borchard, who had "devoted two weeks to an examination of plans, material and data, which Mr. Andrews had collected during many 
report emphasized restatement of the law, which, "instituted and supported by the American Bar Association ... will, it is believed, constitute the most important public service rendered to our law during the past century." Yet, restatement could be undertaken only after agreement on classification ("the analytical and synthetical work of discovering the order and relationships of the elementary concepts of the law"). ${ }^{278}$ After noting Root's 1916 reference to the Corpus Juris Project the report suggested the ABA cooperate with the Academy of Jurisprudence "and utilize it for the purpose of a permanent organization." 279 On the floor, Andrews urged passage of a resolution authorizing the Special Committee and the Executive Committee "to take such steps as may be deemed necessary and expedient to cooperate with any body which has for its purpose the carrying on of the proposed work of classification and restatement of law."280

Andrews's remarks prompted a question from Edward Keasbey, whose long-standing Committee on Reports and Digests had ended the year before: "I would like to ask who the body is that is to perform this work." ${ }^{281}$ In answer, Andrews said that the idea was not to designate a particular organization, but to leave that for next year's Committee and the Executive Committee to determine. Keasbey pressed: "I was wondering whether this contemplates a code of laws or a statement of the common law as it is today." Andrews informed Keasbey that there had never been such unity on the subject of jurisprudence as now, then paraphrased the passage from the Committee report regarding cooperation with the Academy. ${ }^{282}$

Keasbey then asked "whether the purpose of the committee was to prepare a code of laws based upon the common law, or merely to gather together a declaration of what has become the law as heretofore developed," 283 and again "whether the result is to be a statement of the law as heretofore developed, and whether that statement is to change the processes of legal action." Clearly annoyed, Andrews replied: "It would be presumptuous on my part ... to state what form the proposed classification and restatement should take," but he went on to describe the comprehensiveness of the classification envisioned in the report, concluding: "Manifestly such a thing as this could not be a code. There is no code that was ever made that is more than a partial restatement of the law." ${ }^{284}$ After some mystifying comments from D.L. King of Arkansas regarding Blackstone, Jefferson and Napoleon, the Louisiana Purchase, and the source of the Nile, Andrews's motion passed. ${ }^{285}$

In May 1921, Pound and Williston met with Frederick Bunn, who Andrews had introduced as the general business manager for Academy projects, ${ }^{286}$ to discuss the three-part The Codex Library

\footnotetext{
years' consideration of the subject's efforts to examine the available plans and materials on questions of classification and restatement." Id. at 422-423.

${ }^{278} I d$. at 423.

279 Id. at 426.

${ }^{280}$ See Transactions of the Forty-Third Annual Meeting of the American Bar Association, 43 ANN. REP. A.B.A. 19, 84, (1920) (italics added).

${ }^{281} \mathrm{Id}$. at 85 .

282 Id.

${ }^{283} \mathrm{Id}$.

${ }^{284} \mathrm{Id}$. at 86.

285 Transactions of the Forty-Third Annual Meeting supra note 280 at 86-87. For comment, see Editorial Note: The American Bar Association Meeting, 15 ILL. L. REV. 198, 210 (1920) ("The discussion disclosed some fantastic notions as to what classification and restatement signify.").

${ }^{286}$ Letter from James D. Andrews to Roscoe Pound (May 4, 1921) (Copy on file with author).
} 
which would be made public the following March. ${ }^{287}$ After the meeting, Pound wrote Andrews that he and Williston could not endorse so costly a project until more details were settled. Rather than planning "for an institutional treatise, a doctrinal restatement and a selection of leading cases," the Harvard professors thought the Academy should focus on developing a classification plan and an institutional treatise. He closed by asking: "Why can't we get to work in the Committee on Classification and publish a real report that will be worth while [sic]?" By 1922, the Committee should be able to produce a report that would "settle thoroughly the question whether or not an adequate common-law classification of Anglo-American law can be devised by American lawyers." 288 Not surprisingly, Andrews requested to meet Pound, suggesting that after "a couple of two or three hour conferences . . a all matters can be adjusted." He believed that classification should have a year's study by qualified representatives of "different localities and branches of the profession." 289

In August he circulated a short draft report for the Special Classification Committee, commenting that it showed the progress made "so far as it is desirable to make it public at this time," even though he regretted that there had not been enough work to justify the expense of a Committee meeting during the year. ${ }^{290}$ At the 1921 ABA meeting, Andrews read the Special Committee report but made no other remarks. ${ }^{291}$ The report rehearsed the events of the previous two years, stating that in 1920 the Committee had recommended that the association cooperate with the Academy of Jurisprudence, and that the Academy had named a committee to work with the ABA to create an organization to accomplish the work of classification and restatement. ${ }^{292}$ The report then quoted in full an April 1921 ABA Executive Committee resolution which stated the "opinion that this Association should cooperate with the Academy "in an effort to bring about a systematic classification and restatement of the law." Formation of a corporation for this purpose, however, would be better left to individuals than to the ABA, and "any and all specific plans [for accomplishing the work] should be carefully considered and worked out by the special committee and presented to [the Executive Committee] for reference to the Association before taking any action thereon." 293

\footnotetext{
${ }^{287}$ See THE ClASSIFICATION AND RESTATEMENT OF THE LAW UNDER COOPERATIVE DIRECTION OF THE AMERICAN BAR ASSOCIATION AND THE AMERICAN ACADEMY OF JURISPRUDENCE 6 (1922).

${ }^{288}$ Letter from Roscoe Pound to James D. Andrews (May 6, 1921) (Copy on file with author).

${ }^{289}$ Letter from James D. Andrews to Roscoe Pound (May 10, 1921) (Copy on file with author). In a handwritten postscript, Andrews suggested that Williston too be part of the proposed meetings. In July he wired Pound to ask: "When and where can I see you next week?" Telegram from James D. Andrews to Roscoe Pound (July 14, 1921) (Copy on file with author).

${ }^{290}$ Letter from James D. Andrews to Roscoe Pound (August 20, 1921) (with enclosure) (Copy on file with author). The Special Committee now included both Keasbey and Pound. The final committee report tracked the draft Andrews had circulated in August but eliminated several pages of comments on the Roman and Civil Law.

${ }^{291}$ Transactions of the Forty-Third Annual Meeting supra note 280 at 77.

${ }^{292}$ Report of the Special Committee on Classification and Restatement of Law, 44 ANN. REP. A.B.A. 481, 482 (1921). The 1920 report had suggested, but not actually recommended, that the ABA cooperate with the Academy. See Report of the Special Committee (1920), supra note 277 at 426.

${ }^{293}$ Id. at 482. The Special Committee report was accepted without debate. See Transactions of the Forty-Third Annual Meeting, supra note 280 at 77.

The 1921 ABA Annual Report notes a January Executive Committee meeting, but does not mention an April meeting. See Report of the Executive Committee, 44 AnN. REP. A.B.A. 108, 108 (1921). The ABA Journal also reported only on the January meeting, although it does note the appointment in January of a subcommittee to review the 1920 resolution regarding cooperation with the American Academy of Jurisprudence. See Executive Committee
} 
In January ABA President Cordenio Severance assigned two executive committee members to review Andrews's proposals regarding cooperation with the Academy of Jurisprudence. ${ }^{294}$ In April Andrews reported to Taft that William Brosmith and Thomas Shelton of the ABA had spent two days with him and given their full approval to the project. ${ }^{295}$ The primary purpose of Andrews's letter was to offer Taft the chance to resign the Academy presidency, something Taft had attempted to do in December 1916. ${ }^{296}$ Andrews wrote that he had delayed making the proposal "until the organization had reached such a stage that you would be pleased that you had been in at the beginning and would be glad to resign the presidency and become an honorary member." A day later, Taft wrote a short letter to Andrews, tendering his resignation from the presidency of the Academy due to the demands of his position on the Supreme Court. He urged immediate acceptance. ${ }^{297}$ Andrews accepted the resignation without comment. ${ }^{298}$

A March 1922 pamphlet announced the formation of the Academy Publishing Company to conduct business operations for the ABA and the Academy of Jurisprudence, including publication of the Codex Library: "a practical law library embracing the whole legal system ... the only means of simplifying the law." ${ }^{299}$ The Library would have three parts: the Institutes, a two volume presentation of the elements of the law in scientific classification; the Codex, a comprehensive 20 volume classified statement of United States law; and a one hundred volume collection of leading and illustrative American and English cases organized under the classification used in the other parts. Like Andrews's earlier proposals, the pamphlet sketched an organizational structure featuring prominent names ${ }^{300}$ and a brief financial plan, this time projecting income by subscription, including 1,000 "patrons of jurisprudence" who would each pay $\$ 800.00$. $^{301}$ The pamphlet was fleshed out with quotations stating the need for the project.

In May, Andrews sent the pamphlet to Pound, along with a draft committee report for the upcoming $\mathrm{ABA}$ meeting and a list of subscribers to "the organization fund of the American Academy of Jurisprudence." The accompanying letter noted that Andrews expected to move forward with a system of classification after the ABA meeting and had "reason to hope that we shall have financial resources sufficient to push the work of Restatement along on all lines." 302 In

Decisions, 7 A.B.A.J. 51, 52 (1921). The ABA has no Executive Committee minutes from 1921 or 1922. See Email from Richard Collins to Jane Bahnson (March 16, 2017) (Copy on file with author).

${ }^{294}$ Association Will Meet at San Francisco, 8 A.B.A. J. 5, 6 (1922).

${ }^{295}$ Letter from James D. Andrews to William. H. Taft (Apr. 11, 1922) (Taft Papers Series 3 Reel 241) (Copy on file with author). The Taft Papers indicate suggest that this was the first correspondence between the two since 1917 .

${ }^{296}$ See text accompanying notes [248-52] supra.

${ }^{297}$ Letter from William. H. Taft to James D. Andrews (Apr. 12, 1922) (Taft Papers Series 3 Reel 241) (Copy on file with author).

${ }^{298}$ Letter from James D. Andrews to William. H. Taft (Apr. 13, 1922) (Taft Papers Series 3 Reel 241) (Copy on file with author). Taft paid $\$ 100.00$ for a subscription to the books to be published by the Academy and the ABA. See Letter from Secretary to the Chief Justice to James D. Andrews (Apr. 14, 1922) (enclosure) (Taft Papers Series 3 Reel 241) (Copy on file with author).

${ }^{299}$ THE CLASSIFICATION AND RESTATEMENT OF THE LAW, supra note 287 at 6.

${ }^{300} \mathrm{Id}$. at 2. James Brown Scott, Secretary of the Carnegie Foundation for Peace, was president of the company; Frederick Wadhams, current treasurer of the ABA, the treasurer; Andrews, Chair of the Board of Editors; Pound, Chair of the Advisory Council.

${ }^{301} I d$. at 9 .

${ }^{302}$ Letter from James D. Andrews to Roscoe Pound (May 17, 1922) (copy on file with author). Andrews's letter, presumably sent to other members of the classification committee as well as to Pound, used letterhead of the Academy Publishing Company with the original address for the company crossed out and 43 Exchange Place written in. 
early June, newspapers nationally carried stories about the project and the collaboration between the Academy and the ABA. ${ }^{303}$

The 1922 Special Committee report began with a resolution to make it a standing committee of the ABA charged to work with the Executive Committee and the American Academy of Jurisprudence on "the plans and work of Classifying and Restating the Law." 304 When the report came to the floor at the annual meeting in August, however, Secretary Thomas Kemp presented a substitute resolution from the Executive Committee, stating the opinion "that it is not expedient for the American Bar Association to endorse at this time any specific plan or work of classifying and restating the law," and resolving that the Special Committee resolution be rejected. ${ }^{305}$

When Kemp finished, Andrews rose to argue that the substitute resolution would "undo all of the work that has been done during the past five years" 306 pointing out that in April 1921 the Executive Committee had authorized his committee to cooperate with the Academy of Jurisprudence in the effort to classify the law, although not to form a corporation for that purpose. He then presented an April 27, 1921 letter from Kemp which included the Executive Committee resolutions quoted in the 1921 Special Committee report. ${ }^{307}$ On the strength of those resolutions, the Academy Publishing Company had been formed to carry out "the practical working of a systematic restatement" and "for the purpose ... of conducting business which this Association is not organized or adapted to conduct." 308

Arguing that "we have marched forward steadily, cautiously, conservatively," Andrews suggested that he had proposed the appointment of an Executive Committee subcommittee to review the plans for organizing the company. After meeting with him, the sub-committee members had "have written to me that their report would be a favorable one, [and] signed the order for a set of the books." 309 He had been unable to see a copy of the subcommittee report, however, noting that it was omitted from the Executive Committee's own report on its activities for the year. ${ }^{310} \mathrm{He}$ described the Executive Committee as "a very powerful body.... I am sorry for this committeeI am truly. They, on the whole, mean to do right. If they are not coerced or frightened, they generally do right." "311 He saw two reasons for the Executive Committee's action: either it was responding to recent actions by the AALS and other groups toward establishing what in 1923 would become the American Law Institute; or it was not prepared to go forward with the plan he had submitted. Were that the case, the Committee should "amend it and perfect" the plan: "the

\footnotetext{
${ }^{303}$ See, e.g., Seek to Simplify Laws: Taft, Hughes, Root and Other Leading Lawyers in Movement, WASHINGTON Post, Feb. 5, 1922, at 6; To Unify Methods of Teaching Law, DAILY Herald (Gulfport, Miss.), Feb. 6, 1922 at 4; Plan Methods to Unify Law, LOS ANGELES TIMES, June 11, 1922, at III41

${ }^{304}$ Report of the Special Committee on the Classification and Restatement of the Law, 45 ANN. REP. A.B.A. 391, 391 (1922).

${ }^{305}$ Transactions of the Forty-Fifth Annual Meeting of the American Bar Association, 45 ANN. REP. A.B.A. 19, 83 (1922). Beyond Kemp's presentation and the ensuing discussion, neither the 1922 proceedings nor the ABA Journal provide information regarding the substitute resolution. The ABA has no minutes for Executive Committee meetings in 1922. See Email from Collins to Bahnson (March 16, 2017), supra note 293.

${ }^{306} \mathrm{Id}$. at 84 . (Andrews later acknowledged that his resolution could not be approved in its entirety because the special committee could become a standing committee only by constitutional amendment. Id at 89.)

${ }^{307}$ Kemp read the letter from the floor. See Transactions of the Forty-Fifth Annual Meeting, supra note 305 at 85.

${ }^{308} I d$. at 86.

${ }^{309} I d$. at $86-87$.

${ }^{310} \mathrm{Id}$. at $87-88$.

${ }^{311} I d$. at 88
} 
idea that this report, as a whole, completely, and this whole project, shall be turned down, rejected, smothered, within the period of, you may say, a few weeks - is a proposition that I am opposed to utterly." 312

Andrews then moved that the Special Committee report be received by the Association, but not adopted. After that motion was approved, ${ }^{313}$ he proposed a substitute motion to that of the Executive Committee, which would direct the Special Committee (with the Executive Committee) to cooperate with the American Academy "in the plans and work of classifying and restating the law." 314

George Wickersham, himself a charter member of the Academy of Jurisprudence, immediately spoke in opposition to Andrews's substitute. "The real question is whether that should be done as a commercial matter, this Association taking part in a commercial enterprise, or whether it should be done under appropriate conditions, in a scholarly way, as a matter of sound legal scholarship." 315 He then referred to the March pamphlet issued by the Academy Publishing Company which had "no statement as to what that body is or who compose it." Although the pamphlet described the division of stock between the ABA and the Academy, as well as a subscription plan, Wickersham found "nowhere a statement of when or what the subscribers are to get for their money.... [the plan] is radically deficient in that particular - that the money may be collected and spent and nothing given to the subscribers." 316

In response, Andrews noted that the question of "what is and what is not commercialism" had been part of the discussion of the project "ever since the 'Green Bag' exposition,"” then explained that the organization was legally required to be incorporated, and the care taken to avoid any suspicion that funds might be diverted. The details for the plan were not in the pamphlet but in the contract with the Academy Publishing Company. He described the subscription plan, then attempted to move to discussion of his resolution. 317

At that point, an unidentified speaker asked: "What is the American Academy of Jurisprudence? Who compose it?" Andrews described the group's organization in 1914, identified some of its members, noted that the war had interrupted its activities, and that Root had endorsed it in his 1916 presidential address. Wickersham called out: "Haven't they all resigned?" Andrews acknowledged that three had. When Wickersham asked who they were, Andrews replied: "You haven't resigned. You can resign now. They say the good Indians are the dead Indians, but the good lawyers are the live ones. We are fighting to a finish." 318

W.F. Mason then asked how long it would take to complete the work and what it would cost. After receiving Andrews's replies, he asked: "Is this a scheme to get the book endorsed, a

${ }^{312} \mathrm{Id}$.

${ }^{313} I d$. at 89.

${ }^{314} I d$. at 90

${ }^{315} \mathrm{Id}$.

${ }^{316} I d$. at 91 . The Committee report referred to the prospectus for the project, noting that "[i]t would unnecessarily increase the size of this report to enter into the details of the plans and processes whereby this work is to be carried out." See Report of the Special Committee (1922), supra note 304 at 392 Andrews's draft report had included more direct references to the availability of the "pamphlet or prospectus." See Enclosure, Letter from Andrews to Pound (May 17, 1922) supra note 302 at 2.

317 Transactions of the Forty-Fifth Annual Meeting, supra note 305 at 91-93

${ }^{318} I d$. at 94 
publication not in being?" After Andrews said yes, Mason asked whether it would have any authority, "be binding on anybody at all?" Andrews said no, and Mason replied: "In other words, it means another scheme to have the lawyers of this country buy another set of books." Andrews: "If you want to call it a scheme, well and good." 319

The president called the question. Andrews's substitute motion was defeated and the Executive Committee resolution approved. Andrews then moved that the Special Committee be continued. That, too, was approved. ${ }^{320}$

In 1923, new chair Thomas Parkinson reported on behalf of an enlarged Classification Committee with few members from the previous year, Andrews was not among them; after 1923, his name no longer appears in the lists of ABA members published annually in the proceedings. Parkinson's written report acknowledged that the Association had "declared its unwillingness to endorse at that time any specific plan of classifying or restating the law," 321 but then detailed the organization of the American Law Institute, concluding that the ALI "seems in the way of accomplishing the reclassification and restatement of the law which this Association and this committee have long been working toward." 322

When the ABA met in August, William Draper Lewis reported on the ALI's initial activities and plans, pointing out that, although it would be unwise for the ALI to have an "organic connection" with the ABA, ${ }^{323}$ "we need your co-operation; the friendly but searching criticisms and helpful suggestions of your committees on our work and the various drafts of the restatement of different topics." ${ }^{324}$ However, when Parkinson presented the Classification Committee report, he sharply stressed the importance of the ALI's seeking the advice of the bar before the restatements were finalized. No matter the brilliance of those who put themselves to the task, the project could not be successful without "the intelligent cooperation, criticism, and suggestion of the great body of the Bench and Bar." 325

\footnotetext{
319 Id. at $94-95$

${ }^{320}$ Id. at 95-96. A colorful description of the discussion on the Special Committee report is at Largest Meeting in Association's History, 8 A.B.A. J. 553, 573-74 (1922). The Illinois Law Review reported that "[t]he most sensational feature of the [ABA] meeting was the formal repudiation by the Association of the relations which had been established with Mr. James D. Andrews and associates." H.H., Great Publishing Scheme is Repudiated, 17 ILL. L. REV. 314, 314 (1922). The article noted that previous reports from Andrews's committee "all had a cosmic vagueness," but the practical implications of the project became clear when the $\$ 800$ price for the books to be produced was known. Still, the ABA's action "does not necessarily imply hostility to the theory of restatement of the law." Id. at 316.

A few years earlier the Review had attempted to organize a symposium on classification, but received papers only from Andrews and Henry Terry. See Henry T. Terry, Arrangement of the Law, 15 ILL. L. REV. 61 (1920); James DeWitt Andrews, Classification and Restatement of the Law, 14 ILL. L. REV. (1920); Classification and Restatement of the Law [Concluded], 14 ILL. L. REV. 622 (1920).

${ }^{321}$ Report of the Special Committee on the Classification and Restatement of the Law, 46 ANN. REP. A.B.A. 364 , 364 (1923).

${ }^{322}$ Id. at $364-365$

${ }^{323}$ Transactions of the Forty-Sixth Annual Meeting of the American Bar Association, 46 ANN. REP. A.B.A. 19, 95 (1923) (comments of William Draper Lewis) ("The constructive scientific character of the work of the Institute makes it necessary for us to have a constitution which will insure the continuance of a definite policy.") ${ }^{324} \mathrm{Id}$.

${ }^{325}$ Id. at 109 (remarks of Thomas I. Parkinson). The committee's resolution that it be continued for purposes of cooperating with the ALI was unanimously approved. Id.
} 
The following year, reporting on the progress of the ALI, Lewis seemed to respond to Parkinson's comments, explaining that no part of a Restatement could be approved until after interested and experienced members of the ABA or state bar associations "had an opportunity to examine the text of the proposed Restatement and make criticisms and suggestions. ... [T] he Restatement when officially issued must be the product not merely of the work of specialists but also of wide discussion among judges, lawyers and law teachers." 326

The Special Committee made no written report in 1924. On the floor, Parkinson commented that the ALI had "not yet reached the point where your committee can effectively offer criticism or suggestion," and asked that it be continued. ${ }^{327}$ In 1925 no one responded from the floor when President Davis asked the Special Committee to report, ${ }^{328}$ and it was not on the list of special committees appointed for 1925-1926.

\section{Classification and the American Law Institute}

The 1923 report urging establishment of the ALI found that the problems of delay and uncertainty in American law would be best resolved by a restatement of the law with authority greater than that accorded existing encyclopedias and treatises. ${ }^{329}$ The report concluded that it was not "desirable to postpone the work of restating the law of any topic until a complete classification of the law and a complete legal terminology is adopted." 330 Albert Kocourek observed that "for the present, at least, [the ALI] does not seem to be disturbed by the need of classification," 331 or

326 Statement of William Draper Lewis, 47 Ann. Rep. A.B.A. 272, 273 (1924)

${ }^{327}$ Proceedings of the Forty-Seventh Annual Meeting of the American Bar Association, 47 ANN. REP. A.B.A. 27, 3940 (1924) (comments of Thomas I. Parkinson).

328 See Proceedings of the Forty-Eighth Annual Meeting of the American Bar Association, 48 ANN. REP. A.B.A. 27, 82 (1925).

${ }^{329}$ Report of the Committee on the Establishment of a Permanent Organization for the Improvement of the Law Proposing the Establishment of an American Law Institute, 1 A.L.I. PROC. 1, 13 (1923).

The term "restatement" had evolved from the late nineteenth century when it was sometimes used as a synonym (or less inflammatory alternative) for codification. See, e.g., Dillon, Law Reports (1886), supra note 33 at 261

("There inevitably comes a stage in the legal history of every people when its laws become 'so voluminous and vast' that an authoritative and systematic recompilation or restatement of them, to the end that they

may be accessible, and ... cognoscible to those who are governed by them ...."); DILLON (1894), supra note 27 at 386 (suggesting that "the work of jurists and legislators during the next century will be pre-eminently the work of systematic restatement, probably in sections, of the body of our jurisprudence. Call it a code, or what you will, this work must be done.").

${ }^{330}$ Report of the Committee on the Establishment, supra note 329 at 46:

It is not merely that such classification and terminology would necessarily take many years to prepare, though that in itself is a serious objection to this method of proceeding, because it would so far postpone any practical results as to make the establishment of the Institute improbable. The fundamental objection is that a complete and satisfactory classification and terminology can more certainly be produced as the result of actual experience in the work of restating the different subjects. The danger of all classification pursued as an end in itself, is that when actual problems of classification arise, the classification fails to indicate a place for every state of facts. A priori classification has also a tendency to stress unimportant distinctions and invent strange legal terms. It is of course necessary to have from the start a general analysis of the law, and the part of such analysis which affects the topics first undertaken must be thoroughly thought out. Id. at 46-47.

In April 1923, Harlan Stone rejected John Salmond's call for codification of the common law with in favor of restatement along lines similar to what the ALI would propose. See Harlan F. Stone, Some Aspects of the Problem of Law Simplification, 23 COLUM. L. REV. 319, 330-36 (1923) (noting that the common law "defies classification." Id. at 322), commenting on John W. Salmond, the Literature of Law, 22 COLUM. L. REV. 197 (1922).

331 A. K. [Albert Kocourek], Classification of the Law, 18 ILL. L. REV. 260, 261 (1923). 
how the restatements would avoid the duplication "which is inevitable where the old categories are followed unrefined by juristic analysis." 332 The report did acknowledge the need for "division of topics based on a definite classification of the law."333

The ALI "Plan of Work, Organization and Budget" specified that "at the outset some analysis of the law should be made with a view of designating the general scope of the principal topics and the specific scope of the topics first undertaken for restatement," 334 and recommended that the Council "appoint a person in whom they have confidence, whose duty it shall be to submit at the earliest possible moment a general plan of classification and terminology sufficiently worked out to act in the future as a guide to the selection and scope of topics and to lay the foundation." That person was Roscoe Pound, who hoped that he would soon be able "not only to suggest a scheme of classification sufficiently detailed for all present purposes, but will also be able to present a suggested terminology . ...",335

In July, Pound received a lengthy hand-written letter from Henry Terry, ${ }^{336}$ accompanied by a short typewritten manuscript which stated that it would be "a very serious mistake" for the ALI to start by focusing on particular topics of law:

I am very strongly of the opinion that the first step should be to make an exhaustive analysis of the fundamental conceptions on which the whole law depends, ... and express the results of that analysis in an adequate and scientific terminology; and then with the materials so provided, make an arrangement in outline of the whole body of the law, in which the proper place and the proper limits of each particular topic will be indicated. Without such a general framework separate topics cannot be satisfactorily treated. There will necessarily be much

\footnotetext{
${ }^{332}$ A.K., supra note ___ at 262 (although no topic had been more discussed than classification of the law, "no subject that has been discussed as much has yielded poorer practical results." Id. at 260.). Kocourek favorably reviewed the classification proposed in 1917 by Waldo Morse. See id. at 262-63, discussing WALDO G. MORSE, A STUDY IN LAW AND INDUCTION (1917). Kocourek's other writings on classification include: Various Definitions of Jural Relation, 20 Colum. L. REV. 394 (1920); Classification of Jural Interrelations, 1 B.U. L. REV. 209 (1921); Classification of Law, 11 N.Y.U. L.Q. REV. 319 (1934); 18 ILL. L. REV. 1024 (1934).

${ }^{333}$ Report of the Committee on the Establishment, supra note 329 at 14.

${ }^{334}$ Report of the Executive Committee of the Council on Organization, Work and Budget, 1 A.L.I. PROC. pt. III at 85, 114 (1923).

${ }^{335} \mathrm{Id}$. at 114. Pound was appointed "special adviser on questions of classification and terminology" for a one-year term starting on June 1. See Minutes of the Second Meeting of the Council, May 19, 1923, 1 A.L.I. PROC. pt. III at 28, 41 (1923). Prior to his acceptance, Pound's name was used by the organizers in statements seeking support from the Carnegie Corporation. See Letter from William Draper Lewis to Roscoe Pound (March 22, 1923) (copy available from author). The formal appointment came on May 28. See Letter from William Draper Lewis to Roscoe Pound (May 28, 1923) (copy available from author); Pound accepted on June 13, noting his hesitancy because of the work it would involve in light of his other obligations. See Letter from Roscoe Pound to William Draper Lewis (June 13, 1923) (copy available from author).

336 Terry introduced himself as a new member of the ALI, "particularly interested in the matter of the classification and arrangement of the law." Letter from Henry T. Terry to Roscoe Pound (July 9, 1923) (with enclosure) (copy available from author).

After his 1910 contribution to discussions regarding the Corpus Juris Project, see supra text accompanying notes 129-32, Terry continued to publish well-regarded articles in leading law journals. See e.g., Richard W. Wright, Negligence in the Courts: Introduction and Commentary, 77 Chi.-Kent L. Rev. 425, 504 n.41 (2002) ("The seminal article is Henry T. Terry, Negligence, 29 HARV. L. REV. 40 (1915)"). In 1917, he outlined his proposal for arranging the law in a two-part article in the Columbia Law Review. See Henry T. Terry, The Arrangement of the Law I, 17 ColuM. L. REV. 291 (1917); Henry T. Terry, The Arrangement of the Law II, 17 ColUM. L. REV. 365 (1917) See also Terry, Arrangement of the Law (1920), supra note 320.
} 
confusion and overlapping. I wish to urge as strongly as I can that the preparation of such a scheme of arrangement be the first thing undertaken, and that all attempts at statements of particular topics be deferred until that is done. ${ }^{337}$

In early September Lewis asked Pound to join an upcoming conference of ALI reporters and others to allow them to hear his general ideas on classification and terminology. ${ }^{338}$ Pound replied that his report would have to be "pretty tentative." 339 Seeing that Pound was on the agenda for the conference, Terry asked if he would present a draft of his work. ${ }^{340}$ Pound responded that he would not have material ready for discussion, but offered to meet with Terry if Terry attended the conference. ${ }^{341}$ Their meeting apparently prompted Terry to send a 40-page handwritten "screed" titled: "The Arrangement of the Law." 342 Pound thanked Terry for taking so much trouble, as well as for his good will: "I know this will be of the greatest value to me." 343

In December Lewis inquired about the status of Pound's work, reminding him that he was counting on having the report (preferably including parts on both classification and terminology) ready for the ALI annual meeting in February. ${ }^{344}$ Pound replied that Lewis could count on the classification report in draft form, but he could not make an absolute promise about terminology. ${ }^{345}$

Later that month, Pound commented on the purposes and history of classification at the AALS meeting. At the start he emphasized the limitations of classification: no classification system could do more than to classify; it could not "even help us greatly in solving problems of substantive law." "346 Near the end he offered a short description of the classification used in West's Century Digest, using flaws in the contracts category ${ }^{347}$ to argue: "In other words, if you know the [West] classification and know the law, well and good. The law won't teach you anything about the classification, and the classification won't teach you anything about the law; and yet that is a very workable scheme. Thousands of lawyers for years have used it and have found it perfectly workable." 348

After the address, Edwin Borchard agreed that the purpose of classification was practical utility, but also pointed out that common law lawyers had never been serious about determining "whether a classification other than [West's] purely arbitrary alphabetical classification was justified." ${ }^{439}$ A scientific classification might be desirable, but was "not a need which arises from lack of knowledge of law. It is merely a formal arrangement of the law to enable one more quickly to find

\footnotetext{
337 [Untitled Manuscript], enclosed with Letter from Terry to Pound, supra note

${ }^{338}$ Letter from William Draper Lewis to Roscoe Pound (Sept. 3, 1923) (copy available from author).

${ }^{339}$ See Letter from Roscoe Pound to William Draper Lewis (Sept. 20, 1923) ("I have much still to work on which will require a good deal of time.”) (copy available from author).

${ }^{340}$ Letter from Henry T. Terry to Roscoe Pound (Oct.13, 1923) (copy available from author).

${ }^{341}$ Letter from Roscoe Pound to Henry T. Terry (Oct.15, 1923) (copy available from author).

${ }^{342}$ Letter from Henry T. Terry to Roscoe Pound (October 26, 1923) (with enclosure) (copy available from author).

${ }^{343}$ Letter from Roscoe Pound to Henry T. Terry (Oct.15, 1923) (copy available from author).

${ }^{344}$ Letter from William Draper Lewis to Roscoe Pound (Dec. 8, 1923) (copy available from author).

345 See Letter from Roscoe Pound to William Draper Lewis (Dec. 12, 1923) ("I find a great many things to look up in testing various possibilities.") (copy available from author).

346 Roscoe Pound, [Classification of Law], 21 AALS PROC. 82, 82 (1923).

${ }^{347} \mathrm{Id}$. at 91 ("There are some pretty uncomfortable bedfellows in that category of contract, when you come to treat your analysis as anything serious."

${ }^{348} \mathrm{Id}$.

${ }^{349}$ Minutes, 21 AALS Proc. 47, 94 (1923) (comments of Edwin Borchard).
} 
it." He also noted that it was problematic to find books in law libraries arranged by "some scientific plan" rather than alphabetically. ${ }^{350}$

In early February, after sending his report to Lewis, Pound apologized for the delay, blaming eye problems for preventing him from carrying out his original plan and leaving his proposed classification "a bit abbreviated." ${ }^{351}$ Lewis responded that "[t]he report is all right, just what we wanted," and asked Pound for names of people to invite to the discussion at the ALI meeting. ${ }^{352}$ Pound suggested Bates, Cardozo, Learned Hand, and Terry, who he was sure would "be on hand in full force and effect." 353 He wrote Terry to warn him that he was "afraid you will be much disappointed with the report," since it concluded that a classification for teaching and one for the ALI were "two quite different things." 354

Pound's Preliminary Report to the ALI was largely a more formal expression of his December AALS address. ${ }^{355}$ It began by dampening expectations for what classification could accomplish: it could not "render restatement of the law a mere matter of mechanics" or help solve problems of substantive law; nor would it allow a lawyer easily to find an "exact, preappointed legal precept applicable to any problem that may chance to confront him." Despite its importance, classification, "is not a solving device whereby we may obviate the difficulties inherent in ascertaining and applying the law." 356 The body of the report discusses the purposes and history of classification from Gaius through the civil and common law classifications of the nineteenth century, with examples of approaches used in each. Pound singled out Terry as providing "the most complete and most carefully worked out analytical arrangement." ${ }^{357}$ The report concludes with

${ }^{350} I d$. at 95 ("Well, if you know your library your plan is all right, but until you know that library even the scientific plan is not much more helpful to you, I have found, than the alphabetical arrangement.").

${ }^{351}$ See Letter from Roscoe Pound to William Draper Lewis (Feb. 4, 1924) (copy available from author). In late January, Pound's secretary had reported that Pound had been limited in his work because of eye trouble. Letter from Secretary to Dean Pound to William Draper Lewis (Jan. 23, 1924). Pound's biographer writes that after a severe case of childhood measles, Pound's "eyes became sensitive to light and tired easily. In later years he has always worn an eyeshade when working." SAYRE, supra note __ at 36.

${ }^{352}$ Letter from William Draper Lewis to Roscoe Pound (Feb. 7, 1924) copy available from author).

${ }^{353}$ See Letter from Roscoe Pound to William Draper Lewis (Feb. 12, 1924) copy available from author).

${ }^{354}$ Letter from Roscoe Pound to Henry T. Terry (Feb. 7, 1924) (copy available from author). In his report to the ALI, Pound noted that he had benefited from consulting with Terry and admired Terry's work, but believed that "a less analytically generalized arrangement is more suitable for the purposes of the Institute." Roscoe Pound, Preliminary Report to the Council on Classification of the Law, 2 A.L.I. ProC. 381, 419 (1924). Prior to the meeting, he wrote to tell Terry what time the report would be discussed and to make sure Terry received an advance copy. Letter from Roscoe Pound to Henry T. Terry (Feb. 12, 1924) (copy available from author).

Despite Pound's continuing kindness to Terry in personal correspondence, he was more sharply critical in reviewing a paper Terry sent to Lewis for consideration by the ALI. See Minutes of the Ninth Meeting of the Executive Committee, 2 A.L.I. Proc. 182, 195 (1924). Pound noted that Terry was "terribly long-winded," and although he had good things to say, Pound found "nothing that goes much beyond what he said in print long ago." Letter from Roscoe Pound to William Draper Lewis (June 24, 1924) (copy available from author). In a later letter he noted that it was a pity that Terry was "hopelessly prolix," because he has some excellent ideas if he would only consent to put them within reasonable compass." Letter from Roscoe Pound to William Draper Lewis (July 3, 1924) (copy available from author). See also Hull, Restatement and Reform, supra note 19 at 99, n. 85.

355 Pound, Preliminary Report, supra note 354 at 419. For a summary of the report, see Progress is Made in Restatement and Classification of Law, 10 A.B.A J. 157, 157, (1924). Pound's comments are at $i d$. at 197-99, as well as at Minutes of the Second Annual Meeting, 2 A.L.I. Proc. 5, 58 (1924) (comments of Roscoe Pound).

${ }^{356}$ Pound, Preliminary Report, supra note 354 at 381.

${ }^{357} I d$. at 415. Terry's classification is presented at length, but Pound also outlines Andrews's approach in the 1902 Classification Committee report, and the classification of the Century Digest. Id. at 420. 
"suggestions" including several theses on classification, some specific questions, and a suggested "main outline" based on subjects taught in law schools. ${ }^{358}$

At the February Council meeting, Lewis reminded those present that the plan was to begin working on the restatements "without waiting for even a general plan of classification." Pound had been asked for a report on "the main lines along which, for the purposes of the Restatement, we should classify the law." 359 Pound then offered a few comments on the relationship between classification and terminology before discussing the importance for any classification to "flow from a deep study of the common law," rather than from a "so-called universal classification which has grown up for the purpose of a radically different legal system." ${ }^{360}$ Unlike modern Roman law, which is "a law made in the universities," 361 the common law is the work of judges and lawyers whose practical needs require not classification, but books organized to enable them to locate cases. He concluded: "[I]f our law has been able to go along for centuries ... on the basis of alphabetical arrangement, it must at least suggest to us that arrangement does not play any very great part in the development, the working out and shaping of the actual precepts of the law."362

In December, Lewis suggested to the Council that Pound's initial report would "be followed by the suggestion and explanation of a general plan which he believes best suited to the needs of the Institute." He anticipated that conferences with the reporters for individual subjects would result in "a classification based, in its main outlines and divisions, on Dean Pound's Reports, and in its details on the result of practical experience in the work itself." 363 Although he continued to correspond with Lewis regarding the reports on classification and terminology at least into April 1925, Pound completed no more reports for the ALI. ${ }^{364}$

In his 1925 annual report, Lewis acknowledged that some members believed development of a full classification of the law should precede restatement in specific areas, but, because there was no agreement on a single correct system of classification, it was wiser to take the practical approach of focusing first on subjects that any general classification would include (e.g., Agency, Contracts, and Torts). Pound's task had been to study "prior systems of classification and what may be termed the general conditions surrounding the restatement." ${ }^{365}$ Although Pound had not yet been able to

\footnotetext{
${ }^{358}$ Id. at 421-25.

359 William Draper Lewis, Annual Report of the Director, 2 A.L.I. PROC. 27, 28-30 (1924).

${ }^{360}$ Minutes of the Second Annual Meeting, supra note 354 at 60.

361 Id. at 61 .

${ }^{362} \mathrm{Id}$. at 66 . Asked whether a classification based on his thesis would be difficult to accomplish, Pound said that he had found the process "rather difficult," but hoped to have final report a shortly, noting that he would not have undertaken the task had he realized how much time and energy it would take. Id. at 67.

${ }^{363}$ Minutes of the Seventh Meeting of the Council, 2 A.L.I. PROC. 233, 253 (1924) (report of William Draper Lewis).

364 On April 6, Pound wrote that he would be unable to finish the classification report in time for the May ALI meeting: "Unhappily, I have had a great deal of trouble with my eyes, followed by a bad case of Grippe, and that followed by the illness of my secretary for the past three weeks. In consequence I am hopelessly in arrear with everything." Letter from Roscoe Pound to William Draper Lewis (April 6, 1925) (copy available from author). He offered instead to give a preliminary oral report on terminology. Lewis sympathized with Pound's problems but expressed his doubts that there would be time to discuss terminology at the meeting. Letter from William Draper Lewis to Roscoe Pound (April 9, 1925) copy available from author). A few days later, Pound reported that his improving health would soon have him "going again full speed ahead," and he would "be ready presently with the completed report on classification and a first draft on terminology." He concluded that he "perhaps may have something better for you through being compelled to think more and read and write less." Letter from Roscoe Pound to William Draper Lewis (April 11, 1925) (copy available from author).

365 William Draper Lewis, Annual Report of the Director, 3 PROC. A.L.I. 111, 125-26 (1925).
} 
finish the second part of his work. Lewis emphasized that some questions of "very considerable practical importance" could not be determined even by a general classification devised for the Restatement project. ${ }^{366} \mathrm{~A}$ few months later, he told delegates to the ABA meeting that the ALI had "been able to meet questions of classification and terminology as far as has been necessary to meet them at this stage of the work ...."367

With Lewis's approval, ${ }^{368}$ in June, Pound published an article based on his report in the Harvard Law Review, which focused on civil law classification and included neither the comments on common law classification nor the examples included in the report to the ALI. ${ }^{369}$ Again he emphasized that classification could have various purposes: a classification arranged schematically from a pedagogical standpoint might lose its value for restatement of the law or other purposes. ${ }^{370}$ Although it closed with the note: "To be continued," the article was Pound's last published contribution to discussions of classification.

Prior to the publication of his Harvard Law Review article, Pound received a letter from James Andrews, who reported that he had read Pound's comments on classification and restatement, and requested copies of "both" reports. ${ }^{371}$ Unsure to which reports Andrews referred, Pound replied that he would send a copy of the draft report to the ALI, but it would be some time before he could make a report on terminology. He expressed a wish to discuss "these things" with Andrews and hoped to see him at the next ABA meeting. ${ }^{372}$ Andrews wrote back at some length to suggest that the two meet before the ABA meeting and that he hoped "to write fully about the report and the subject matter generally." He asked Pound to assure him that he could "write freely without any fear that you might resent my criticisms," noting little had been accomplished regarding actions and procedure, things he had been studying for many years. ${ }^{373}$

\footnotetext{
${ }^{366} \mathrm{Id}$. at 130 (There was "a class of questions, pertaining to the exact scope, of each subject, which must be solved not beforehand but in the light of knowledge gained from practical experience in doing the work." Id. at 130-31.).

${ }^{367}$ Proceedings of the Forty-Eighth Annual Meeting, supra note___ at 68. (statement of William Draper Lewis).

${ }^{368}$ See Letter from Roscoe Pound to William Draper Lewis (Feb. 26, 1924) (copy available from author); Letter from William Draper Lewis to Roscoe Pound (Feb. 28, 1924) (copy available from author).

${ }^{369}$ Roscoe Pound, Classification of Law, 37 HARV. L. REV. 933 (1924). In 1989 Jay Feinman called Pound

"certainly not the last person to present a classification of legal doctrine, but he was the last to present a

comprehensive approach to the study of classification." Feinman, supra note 18 at 663 n.4 (summarizing the legal classification literature).

In the article, Pound noted that much of what had been written on classification in the nineteenth century was influenced by biological classification, even though those principles were inapplicable to law. Id. at 937. N.E. Hull writes that already in the 1890s, when Pound was in Nebraska completing his legal studies after a year at Harvard while earning a PhD. in Botany, there developed "a dual strain in his jurisprudential nature." Although his early letters showed that he lauded "systematization and classification," Pound "would spend three or more decades espousing a progressive-pragmatic doctrine of jurisprudence that seems at odds with these fussy taxonomies .... There must be something that went beyond mere classification or explanation of law." HULL, ROSCOE POUND AND

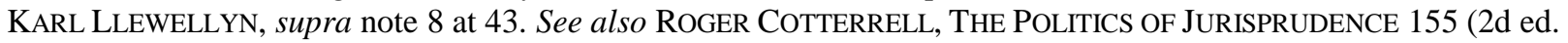
2003) ("Pound's writings contain exhaustive classifications and taxonomies of interests ... [he] seemed to delight in elaborating this scheme of interests, classifying and sub-classifying, and documenting the categories with a mass of illustration from Anglo-American case law.”)

${ }^{370}$ Pound, Classification of Law, supra note 369 at $942-45$.

${ }^{371}$ Letter from James D. Andrews to Roscoe Pound (Apr. 2, 1924) (copy available from author).

${ }^{372}$ Letter from Roscoe Pound to James D. Andrews (Apr. 3, 1924) (copy available from author).

${ }^{373}$ Letter from James D. Andrews to Roscoe Pound (May 5, 1924) (copy available from author).
} 
Andrews also confessed that he had hoped to be asked to work with the ALI, but, although "that, at first, seemed to be the desire and disposition of Messrs. Williston, Beale and Lewis ... no such course was subsequently suggested." Now that he knew more about the ALI plans, Andrews believed that they were "open to much improvement and amendment" and he would "be very glad to co-operate in this work and contribute the result of my many years of study and large accumulation of material." 374 Pound replied that he welcomed Andrews's criticisms of his own draft on classification, but knew nothing about the ALI's plans and organization beyond what was in its published proceedings, even if he had been "asked to do something upon classification and [had] been spending a good deal of time on the matter since." He felt that the ALI planned to proceed cautiously by taking up a few subjects at a time. ${ }^{375}$ This letter seems to have ended their correspondence.

At the May 1926 annual dinner of the ALI, Pound attempted to place the restatement project within an historical context in order to show that, like codification and earlier attempts to develop complete statements of the law, it was the product of a period of societal transition. ${ }^{376}$ Now "the professors in law schools ... are seeking a scientifically organized, logically presented body of experience, not a formulation of universal reasoning. This concrete aspect of the restatement . . is a most favorable sign. For concreteness is in the very spirit of our law." 377 Beyond the nods to scientific organization and logical presentation, Pound neither mentioned nor alluded to classification in his talk. ${ }^{378}$

\footnotetext{
${ }^{374}$ Id. In 1921, the scrapped report of the AALS Special Committee on Round Table Conferences and a Juristic Center warned: "If the legal profession does not effectively organize an agency to carry out this duty, individual lawyers and laymen will rashly and ignorantly propose, and in many cases secure, the adoption of crude and superficial remedies." Report of the Special Committee on Round Table Conferences and a Juristic Center, supra note 263 at 13 . Hull suggests that the report was drafted by William Draper Lewis, who "knew and was critical of Andrews's ABA restatement project, and it was partly that venture that prompted this warning against leaving the job of reform to lawyers and laymen." Hull, Restatement and Reform, supra note 19 at 70. Hull also quotes a 1944 letter from Lewis to Rodenbeck in which he wrote: "I never saw Mr. Andrews but once. He explained his project which I thought was fundamentally unsound ...." Id. at 70-71, quoting Letter from William Draper Lewis to Adolph J. Rodenbeck (June 27, 1944) (ALI B58-9).

${ }^{375}$ Letter from Roscoe Pound to James D. Andrews (May 6, 1924) (copy available from author).

${ }^{376}$ Text of Addresses at the Dinner, 4 Proc. A.L.I. 361, 379 (1926) (Comments of Roscoe Pound) ("When new situations create new uncertainties, our well-grounded faith in the legal order leads us to assume that the difficulty must be in the form. The law is there; but it is so ill-stated that men fail to receive the benefit of it." Id. at 384 ). ${ }^{377} I d$. at 385 .

${ }^{378}$ After Pound's 924 Harvard Law Review article, classification became a matter of slight interest to the ABA, the AALS, or the ALI, and was little discussed in the journals. It was discussed at ALI meetings only in terms of issues involving internal organization of specific topics. See e.g., articles by Albert Kocourek, supra, note 332; Edwin W. Patterson, Can Law be Scientific?, 25 ILL. L. REV.121, 128-32 (1930) (cautioning about the limitations of classification in law); Charles C. Ulrich, A Proposed Plan of Classification for the Law, 4 MiCH. L. REV. 226 (1935); and several articles by Urban A. Lavery, largely focusing on the American Digest system: Finding the Law: Legal Classification in America-1880-1940, 25 A.B.A. J. 383 (1939); A Formula for Finding the Law, 25 A.B.A. J. 911 (1939); and The "Findability" of the Law, 27 J. AM. JuD. Soc. 25 (1943); Jerome Hall, Some Basic Questions Regarding Legal Classification for Professional and Scientific Purposes, 5 J. LEgAL EdUC. 329 (1953). Mitchell Franklin, The Historic Function of the American Law Institute: Restatement as Transitional to Codification, 47 HARV. L. REV. 1367, 1384 (1934). More recent discussions are found in Feinman, supra note 18 and Alexander, supra note 16.
} 


\section{Conclusion}

Pound's 1924 article effectively marked the end of a thirty-five-year debate over the value of classifying American law which began when the ABA referred Henry Terry's letter on arrangement of the law to a special committee on classification in 1888. Terry's proposal had little immediate impact, but the special committee continued for nearly twenty years (although often inactive) and provided a first national forum for James DeWitt Andrews, who became the major voice for classification of the law until 1922 when the ABA rebuffed his final efforts in favor of the restatements of the American Law Institute.

Andrews saw classification as essential to jurisprudence, and a means to ensure that lawyers were grounded in the basic principles of American law. He was devoted to the works of the largely-forgotten founding father James Wilson, particularly for Wilson's ideas on classification. After publishing a generally well-received edition of Wilson's works in 1900, Andrews published an attempt at a comprehensive institutional treatise: American Law, which was criticized for minimal treatment of some subjects, but generally praised for his effort to organize and classify the law.

Andrews moved from Chicago to New York City in 1903. ${ }^{379}$ In his obituary, the New York Times reported that he came "to do editorial work, and from that time practiced here and wrote on legal subjects." 380 In 1908 a history of the Illinois county where Andrews had started his legal career described him as "head of a special legal enterprise ... "organized for publishing law books covering all points in American law ... in twenty volumes," an early description of what would be announced in the Green Bag two years later as the Corpus Juris Project. ${ }^{381}$ By 1909 Who's Who in New York listed him as president and managing editor of the Codex Publishing Co. ${ }^{382}$ In 1910, he contributed volumes on Statutory Construction and Jurisprudence and Legal Institutions to

\footnotetext{
379 See [Note], 35 CHI. LeGAL NEWS 411(1903).

In New York Andrews established offices at 220 Broadway, the first of perhaps five addresses that would be on his letterhead for his practice and other projects over the next 20 years. By 1907, 10 Wall Street was the address for his practice, see 3 WHO'S WHO IN NEW YORK CITY AND STATE 35 (John Leonard, ed., 1907) and in 1914 was used on letterhead for the American Academy of Jurisprudence. After 1915, he continued to use the same letterhead for Academy correspondence, but as he moved offices crossed out the Wall Street address and typed or wrote in at least three later locations. After the Academy ended, at least by 1924 he was using new printed letterhead for his practice.

${ }^{380}$ J. De W. Andrews, Legal Writer, Dies, N.Y. TIMES, Apr. 12, 1928, at 27 (with sub-headline suggesting that Andrews had "Codified American Law"). See also James D. Andrews, in 1 WILLIAM W. DAVIS, HISTORY OF WhITESIDE COUNTY, ILLINOIS FROM ITS EARLIEST SETTLEMENT TO 1908 at 156 (1908) (suggesting that Andrews believed New York "would afford a wider field for achievement.").

${ }^{381}$ See id.

382 Andrews, James DeWitt, in 4 WHO’s WhO IN NEW YORK CITY AND STATE, supra note 96 at 33.
} 
LaSalle Extension University's fourteen volume American Law and Procedure set. ${ }^{383}$ In 19111912, he was supervising editor of three volumes of the Standard Encyclopedia of Procedure. ${ }^{384}$

For the Corpus Juris Project with Lucien Alexander and George Kirchwey, Andrews sought philanthropic support to create a comprehensive classification of American law through an elaborate organization of law teachers and practitioners. When the project failed to interest donors, Andrews organized the American Academy of Jurisprudence, which had similar goals (producing a "scientific and concise statement of the entire body of American law") but would be funded through subscriptions.

The Academy of Jurisprudence was bitterly opposed by John Wigmore (who had also criticized the Corpus Juris Project), but Andrews engaged the interest of a number of prominent lawyers and law professors including Elihu Root, Roscoe Pound, John F. Dillon, and William Howard Taft, some suggesting that they became involved only because they were wary of Andrews's plans. Taft was elected president of the Academy in February 1914, but soon grew weary of Andrews's frequent calls for meetings and ideas for projects. Although Root boosted the Academy's prospects in his 1916 ABA presidential address, Taft attempted to resign the Academy presidency later that year, finally succeeding in 1922 after his appointment to the Supreme Court.

As chair of an ABA special committee to consider classification and restatement of the law from 1920-1922, Andrews developed a joint project for the ABA to work with the Academy to classify and state the law. At its 1922 annual meeting the ABA rejected the proposal in favor of the nascent plans of the American Law Institute, bringing to an end Andrews's twenty-year effort to garner support for a comprehensive classification of American law.

Andrews and Henry Terry both passionately advocated the intrinsic value of classification (or systematic arrangement), but said little about how improved classification might improve the digests lawyers used to locate cases. ${ }^{385}$ Nor did they say much regarding codification, which others viewed as a likely follow-up to classifying the law. ${ }^{386}$ Andrews in particular focused on the close

\footnotetext{
${ }^{383}$ In 1910 the American Law School Review noted that Andrews was co-editor with James Parker Hall, dean of the University of Chicago, of a series of books for the La Salle Extension University intended "to make a systematic, nontechnical presentation of the field of American Law and Procedure taken as a whole." See Samuel MacClintock, Law Instruction in the La Salle Extension University, 2 AM. L. SCH. REV. 411, 412-413. See also News and Notes, 4 AM. POL. SCI. REV. 404, 416 (1910). Hall issued a statement explaining that the project's purpose had changed when new publishers took it over, that he was personally opposed to correspondence study of law, and that there was no joint editorship with Andrews, each man having sole responsibility for his parts of the work. James Parker Hall, $A$ Statement, 2 Am. L. Sch. Rev. 477, 478 (1909).

${ }^{384} \mathrm{He}$ also wrote the introduction to the first volume. See James DeWitt Andrews, Introduction, Including a General Outline of the Forms of Remedial Justice, 1 STANDARD ENCYC. PROC. 1 (Arthur P. Will, ed. 1911).

${ }^{385}$ Terry briefly noted the desirability of reducing the "amorphous bulk" of the law to "a logical and scientific arrangement." Henry T. Terry, Legal Duties and Rights, 12 YALE L.J. 185, 185 (1903). Andrews pointed out that the "actual law lies imbedded in a vast conglomerate of precedents ... concealed by the refuse [and] should be extracted from the mass and given exclusive place in the main text of the books of the law." Andrews, Next Great Step, supra note 69 at 492

${ }^{386}$ In 1884 Terry noted potential benefits of a code developed under ABA sponsorship, but later suggested that lawyers really needed "some arrangement which shall be generally accepted by the bench and the bar and followed by legislators and the writers of treatises and digests." In 1910 Andrews stated that he had been always opposed to "legislative codification of the written law under present conditions," but was not "opposed to the codification of the written and the unwritten law as blended parts of one system." Andrews, Classification of Law, supra note 136 at 574.
} 
connections between classification and jurisprudence: "Classification is clearly the basis of logical science; classification is an essential part of the definition of jurisprudence; classification is an essential part of the work of codification and of systematic consolidation." ${ }^{387} \mathrm{He}$ told an audience of law librarians: "It is the province of jurisprudence to give order and simplicity to the multitude of principles, doctrines and rules which must needs exist in a complex society...."388 He told the members of the ABA that the "primary, paramount object of this association [is] the promotion of jurisprudence; or one might almost say, the creation of jurisprudence; until we have a systematic body of law systematized we cannot have a jurisprudence." 389

He organized his 1900 American Law treatise using his own classification, receiving praise from some reviewers, and offered a partial classification based on James Wilson's ideas in a report he prepared for the ABA in 1902. Wigmore, Taft, sometimes Pound, and others questioned whether his main motivation was promoting his own approach. Wigmore argued that Andrews: "has long possessed the conviction that his theory of law and legal classification is the only one meriting adoption in this country; that he has applied his powerful will and assiduous industry to obtaining that adoption ..." ${ }^{390}$ Reviewing the second edition of Andrews's American Law treatise, Pound found Andrews's approach to be "thoroughly and frankly eighteenth century." 391 Later he shared his hesitations about Andrews with Wigmore, and told Harlan Stone: "I do not believe in the project at all," but remained on the ABA Classification Committee for fear it would "get into the hands of a lot of enthusiasts who will put across a half-baked project which will do infinite harm."

In 1914, when Taft suggested to Andrews that the members of the American Academy had joined "for the purpose of promoting the publication of the law on the theory which you have heretofore advanced," 392 Andrews responded that it had been "expressly stated" that the Academy was committed to no specific plan for classification, "nor the promotion of any publication which I have proposed," 393 and that he had "at all times taken pains to negative any impression that by joining the Academy the members expressly or tacitly committed themselves to [his] plans of Classification." 394 He admitted that he had devoted years to "examining the data and studying the processes of classical and modern Jurists and reformers" and that, while his own conclusions might not be right and his plans impractical, they were worthy of consideration. ${ }^{395}$ He consistently argued that individual effort alone could not accomplish his goals: In 1910 he wrote: "The work cannot be and should not be the work or one man, nor should any one man assume to dominate any part of it." ${ }^{396}$ In 1920 he told the ABA: "It would be presumptuous on my part ... to state what form the proposed classification and restatement should take."

William Draper Lewis and other leaders of the restatement movement of the ALI had little interest in comprehensive classification projects and ignored Andrews's (as well as Terry's)

\footnotetext{
387 Andrews, Next Great Step, supra note 69 at 489

388 Andrews, Use of the Law Library, supra note 114 at 10.

389 Transactions of the Twenty-Eighth Annual Meeting, supra note 88 at 85.

${ }^{390}$ Letter from Wigmore to Taft, etc., supra note 176 at 8.

${ }^{391}$ See R.P. [Roscoe Pound], Book Review, supra note 78 at 485.

392 See Letter from Taft to Andrews (June 3, 1914), supra note 212.

${ }^{393}$ Letter from Andrews to Taft (July 6, 1914), supra note 214.

${ }^{394}$ Letter from Andrews to Taft (Sept. 14, 1914), supra note 215 at 1.

${ }^{395}$ Letter from Andrews to Taft (Oct. 7, 1914) I, supra note 218.

${ }^{396}$ Andrews, Next Great Step, supra note 69 at 504.
} 
attempts to participate in the restatement project. To avoid becoming bogged down in debates over competing classification schemes, the ALI asked Roscoe Pound to deliver a classification only "sufficiently worked out" to begin the writing of individual restatements.

Pound had joined the American Academy and served on ABA committees devoted to classification, but also believed that scientific classification had limited value for the common law. Although the works of Blackstone and Kent "to all intent and purpose, furnish a science of law. ... [t]heir arrangement or analysis is not scientific, but it is concrete and adapted to law-men." 397 In 1924 he would tell the ALI: "[I]f our law has been able to go along for centuries ... on the basis of alphabetical arrangement, it must at least suggest to us that arrangement does not play any very great part in the development, the working out and shaping of the actual precepts of the law."398

Andrews disagreed. As Pound pointed out when he placed Andrews's philosophy in earlier centuries, Andrews lamented the loss of a time in which lawyers studied and understood the principles of the common law, and felt less bound to focus on the facts and results of recent cases pouring from the courts. Robert Bone saw his work as inspired by his belief in "discoverable principles implicit in the ever-growing corpus of judicial decisions" 399 Andrews believed that classification would bring the principles to the forefront, placing him with those who N.E.H. Hull called "older formalists" who saw classification as a way to deal with the inconsistencies in the law caused by the late nineteenth century growth in published reports of cases. ${ }^{400}$

In the end, however, the Andrews's dreams for comprehensive scientific classification of American law foundered (like those of Henry Terry) in the face of the practical needs of American "law-men," which were met by the less scientific, but more practical, efforts of what Bench and Bar called the "wonderful digests of the West Publishing Company," approaches of the academics and others who created the restatements of the American Law Institute.

\footnotetext{
${ }^{397}$ Roscoe Pound, The New Philosophies of Law, 27 HARV. L. REV. 718, 721 (1914)

${ }^{398}$ Minutes of the Second Annual Meeting, supra note 354 at 61. Pound was also dubious about the possibilities for codification of American law. See e.g., Roscoe Pound, Do We Need a Philosophy of Law, 5 COLUM. L. REV. 339 , 343 (1905) (explaining why "codification, as such, is still far remote"); Roscoe Pound, Regulation of Judicial Procedure by Rules of the Court, 10 ILL. L. REV. 163, 166 (1915-1916) ("No lawyer, at least, supposes today that such a code is expedient or even possible with respect to the substantive law.").

399 See Bone, supra note 77 at 1113 n. 14.

400 See Hull, Restatement and Reform, supra note 19 at 57.

${ }^{401}$ See "To Harmonize the Legal Systems of the States," supra note 49 at 36. Although it was rarely considered in discussions of "scientific" classifications, John Mallory, the primary developer of West's classification system, seems to have seen it as more rigorous than others did. See Richard A. Danner, Influences of the Digest Classification System: What Can We Know? 33 LEGAL REF. SERV. Q. 117, 149-50 (2014).
} 